REORDENAMENTO DOS SERVIÇOS

DE ACOLHIMENTO DE CRIANÇAS

E ADOLESCENTES E IMPLEMENTAÇÃO

DE NOVAS MODALIDADES - FAMÍLIA

ACOLHEDORA E REPÚBLICAS (2010-2018) 

REORDENAMENTO DOS SERVIÇOS DE ACOLHIMENTO DE CRIANÇAS E ADOLESCENTES E IMPLEMENTAÇÃO DE NOVAS MODALIDADES - FAMÍLIA ACOLHEDORA E REPÚBLICAS (2010-2018) 


\section{Governo Federal}

Ministério da Economia

Ministro Paulo Guedes

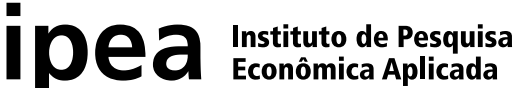

Fundação pública vinculada ao Ministério da Economia, o Ipea fornece suporte técnico e institucional às ações governamentais - possibilitando a formulação de inúmeras políticas públicas e programas de desenvolvimento brasileiros - e disponibiliza, para a sociedade, pesquisas e estudos realizados por seus técnicos.

\section{Presidente}

Carlos von Doellinger

Diretor de Desenvolvimento Institucional

Manoel Rodrigues Junior

Diretora de Estudos e Políticas do Estado, das Instituições e da Democracia

Flávia de Holanda Schmidt

Diretor de Estudos e Políticas

Macroeconômicas

José Ronaldo de Castro Souza Júnior

Diretor de Estudos e Políticas Regionais, Urbanas e Ambientais

Nilo Luiz Saccaro Júnior

Diretor de Estudos e Políticas Setoriais de Inovação e Infraestrutura

André Tortato Rauen

Diretora de Estudos e Políticas Sociais

Lenita Maria Turchi

Diretor de Estudos e Relações Econômicas

e Políticas Internacionais

Ivan Tiago Machado Oliveira

Assessor-chefe de Imprensa e Comunicação

André Reis Diniz

Ouvidoria: http://www.ipea.gov.br/ouvidoria

URL: http://www.ipea.gov.br 
REORDENAMENTO DOS SERVIÇOS DE ACOLHIMENTO DE CRIANÇAS E ADOLESCENTES E IMPLEMENTAÇÃO DE NOVAS MODALIDADES - FAMÍLIA ACOLHEDORA E REPÚBLICAS (2010-2018) 


\section{EQUIPE TÉCNICA}

\section{Elaine Cristina Licio}

Especialista em políticas públicas e gestão governamental, lotada no Ipea.

\section{Marina Brito Pinheiro}

Pesquisadora no Subprograma de Pesquisa para o Desenvolvimento Nacional (PNPD).

\section{Marco Antônio Carvalho Natalino}

Especialista em políticas públicas e gestão governamental, lotado no Ipea.

\section{Enid Rocha Andrade da Silva}

Técnica de planejamento e pesquisa do Ipea.

\section{Aline Diniz Amaral}

Especialista em políticas públicas e gestão governamental, lotada no Ipea.

As publicações do Ipea estão disponíveis para download gratuito nos formatos PDF (todas) e EPUB (livros e periódicos). Acesse: http://www.ipea.gov.br/portal/publicacoes

As opiniões emitidas nesta publicação são de exclusiva e inteira responsabilidade dos autores, não exprimindo, necessariamente, o ponto de vista do Instituto de Pesquisa Econômica Aplicada ou do Ministério da Economia.

É permitida a reprodução deste texto e dos dados nele contidos, desde que citada a fonte. Reproduções para fins comerciais são proibidas.

DOI: http://dx.doi.org/10.38116/ri213948 


\section{SUMÁRIO}

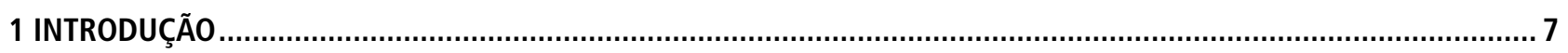

2 O PNCFC E OS SERVIÇOS SOCIOASSISTENCIAIS DE ACOLHIMENTO ................................................................ 10

3 METODOLOGIA

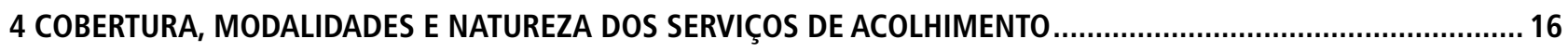

5 SERVIÇOS DE ACOLHIMENTO EM REPÚBLICAS: 0 QUE SÃO E PARA QUEM SE DESTINAM ................................... 52

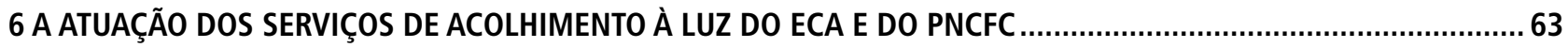

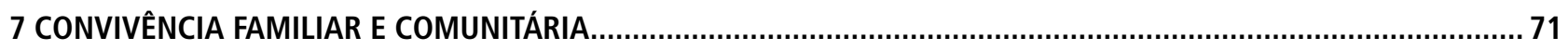

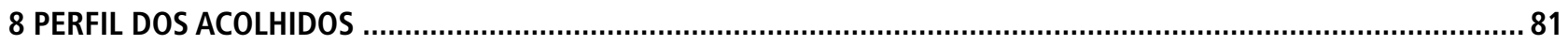

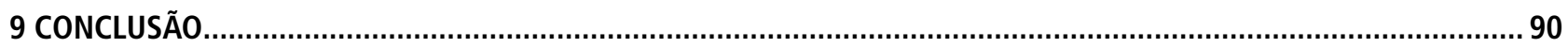

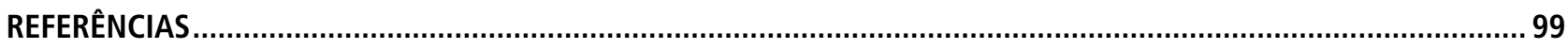





\section{INTRODUÇÃO}

Este relatório tem como objetivo analisar a situação atual e a trajetória dos serviços socioassistenciais de acolhimento voltados para crianças e adolescentes e para os jovens que atingem a maioridade nesses serviços. Os serviços de acolhimento institucional (SAIs), família acolhedora e de repúblicas são ofertados, financiados, regulados e executados no âmbito da política de assistência social. Os dois primeiros atendem a crianças e adolescentes que tiveram direitos ameaçados ou violados e que estáo sob medida protetiva de acolhimento, aplicada por autoridade judiciária ${ }^{1}$ em casos nos quais as famílias/ responsáveis se encontrem temporariamente impossibilitados de cumprir sua função de cuidado e proteção. O serviço de repúblicas, por sua vez, abrange grupos de jovens que foram desligados dos serviços de acolhimento por terem alcançado a maioridade.

Cabe destacar que a medida protetiva de acolhimento possui caráter provisório e excepcional, tendo-se em vista o objetivo precípuo de promover o retorno ao convívio familiar e comunitário na família de origem, ou, se esgotadas todas as possibilidades nesse sentido, o encaminhamento para família substituta, ${ }^{2}$ mediante procedimentos legais que garantam a defesa do superior interesse da criança e do adolescente.

A proteção da criança e do adolescente e seu reconhecimento como sujeito de direito teve como marco tanto a Constituiçáo Federal de 1988 (CF/1988) quanto a promulgação do Estatuto da Criança e do Adolescente - Lei no 8.069/1990 (Brasil, 1990). Com o estatuto, deixa de ser sustentado legalmente, como causa de abrigamento, o princípio da situação irregular. Esse princípio "englobava os casos de delinquência, vitimização e pobreza das crianças e dos adolescentes, além de outras hipóteses extremamente vagas, que autorizavam a atuação amplamente discricionária do Juiz de Menores” (Leite, 2005, p. 12-13). Isso alterou o patamar das discussóes entre governos e a sociedade civil sobre o necessário aperfeiçoamento das políticas públicas relacionadas ao acolhimento desse público, colocando na agenda o superior interesse da criança e do adolescente e a questão de como implementar a nova legislação.

Em 2004, a pesquisa elaborada pelo Ipea e pelo Conselho Nacional dos Direitos da Criança e do Adolescente - Conanda (Silva, 2004) sobre a realidade dos abrigos revelou a continuidade de situaçôes de privaçôes de direitos, com condiçóes muito distantes das preconizadas pelo ECA mais de uma década após sua promulgação. $\mathrm{O}$ caráter de excepcionalidade da medida de abrigo (art. 101, $\$ 1^{\circ}$ do ECA) não era respeitado, sendo a institucionalizaçáo um recurso ainda utilizado de forma indiscriminada. $O$ estudo apontou também que uma das principais causas para o abrigamento de crianças e adolescentes consistia na pobreza das famílias, ainda que o art. 23 do ECA determine que a carência de recursos materiais náo constitua motivo para a perda ou suspensão do poder familiar. Ademais, mais da metade dos abrigados não apenas tinham família, mas também mantinham algum tipo de vínculo com esta. Apenas pouco mais de $10 \%$ estavam disponíveis para adoção. Aliás, o direito da

1. Ver arts. 98 e 101 do Estatuto da Criança e do Adolescente - ECA (Lei no 8.069/1990); em particular, incisos VII e VIII e §§ 2e e 3․ Nos termos do art. 93 "as entidades que mantenham programa de acolhimento institucional poderão, em caráter excepcional e de urgência, acolher crianças e adolescentes sem prévia determinação da autoridade competente, fazendo comunicação do fato em até 24 (vinte e quatro) horas ao Juiz da Infância e da Juventude, sob pena de responsabilidade (Brasil, 1990, arts. 98 e 101)"

2. art. 101, inciso IX do ECA. 
criança e do adolescente era desrespeitado tanto em relação às possibilidades de retorno ao convívio familiar, quanto no que concerne à colocaçáo em adoção. $\mathrm{O}$ tempo de acolhimento era excessivo, sendo que boa parte das crianças e dos adolescentes abrigados $(52,6 \%)$ vivia nas unidades há mais de dois anos. Apenas 54,6\% das crianças e dos adolescentes abrigados nas instituiçóes pesquisadas tinham processo nas varas da Justiça, sendo provável que as demais estivessem acolhidas sem conhecimento judicial. Em suma, o serviço ofertado seguia de baixa qualidade, a pobreza continuava sendo motivo para o afastamento do convívio, e dificultava-se tanto o encaminhamento para adoção quanto o retorno à convivência com a família de origem, indicando um quadro de continuidade de ideias e práticas preconizadas pelo antigo Código de Menores revogado pelo advento do ECA em 1990.

Segundo Pereira, Neris e Melo (2019), diversos estudos realizados ainda no século XX evidenciaram que instituiçóes caracterizadas pelo isolamento social e por cuidados massificados eram incapazes de atender às necessidades de desenvolvimento de crianças e adolescentes, sobretudo no que diz respeito à provisão de vínculos afetivos significativos, estáveis e seguros. Essas e outras constataçóes evidenciaram a necessidade de direcionar o debate para além da adoção, buscando criar condiçóes para garantir o direito de convivência familiar e comunitária. Foi nesse contexto que se elaborou o Plano Nacional de Promoção, Proteção e Defesa do Direito de Crianças e Adolescentes à Convivência Familiar e Comunitária (PNCFC), em 2006, ${ }^{3}$ ao qual se somaram as Diretrizes de Cuidados Alternativos para Crianças (ONU, 2009). Com grande envolvimento de atores governamentais e da sociedade civil, a criaçáo do plano orientou-se pela prevençáo do afastamento do convívio familiar e do rompimento dos vínculos familiares, pela qualificação dos serviços de acolhimento e pelo investimento no retorno ao convívio com a família de origem e, quando esgotada essa possibilidade, na colocação em adoção. O PNCFC apregoa o atendimento humano integral das crianças e adolescentes, por meio de políticas públicas articuladas com vistas à plena garantia dos seus direitos. Nessa perspectiva, reafirma o caráter transversal e intersetorial de suas açóes que envolvem não apenas as políticas sociais, mas também o Poder Judiciário, o Ministério Público (MP), os conselhos tutelares e demais atores que integram o Sistema de Garantia de Direitos da Criança e do Adolescente (SGDCA). ${ }^{4}$ Esse movimento permitiu, inclusive, que o Brasil assumisse posição de destaque no processo de elaboração das diretrizes da Organização das Naçôes Unidas - ONU (Yánez, 2016).

As diretrizes contidas no plano desdobraram-se em diversas mudanças institucionais. Desde então, alterou-se a redação do $\mathrm{ECA}^{5}$ em vários pontos - por exemplo, a exigência de celeridade nos procedimentos de acompanhamento contínuo da situação de crianças e adolescentes acolhidos, de modo a evitar que a permanência no serviço de acolhimento se estenda para além de dezoito meses; a atualização quanto à nomenclatura dos serviços de acolhimento (de programas de abrigo para serviços de acolhimento institucional); a previsão da modalidade de acolhimento familiar em preferência à modalidade de acolhimento institucional; entre outras.

3. Objeto de Resolução Conjunta no 1/2006, aprovada pelo Conanda e pelo Conselho Nacional de Assistência Social (CNAS).

4. Sobre o SGDCA, ver a Resolução Conanda no 133/2016. O SGDCA surgiu em 2006, para assegurar e fortalecer a implementação do ECA. 0 sistema é formado pela integração e a articulação entre o Estado, as famílias e a sociedade civil, para garantir e operacionalizar os direitos das crianças e adolescentes no Brasil.

5. Especialmente as Leis nos 12.010/2009, 13.257/2016 e 13.509/2017. Para saber mais sobre as alterações no ECA em relação ao direito à convivência familiar e comunitária, ver Pereira, Neris e Melo (2019). 
A pesquisa realizada pelo Ipea e pelo Conanda (Silva, 2004) e as diretrizes, os objetivos e as estratégias do PNCFC inspiraram, em 2009, a definição de Orientaçóes Técnicas (2009) para o funcionamento dos serviços socioassistenciais de acolhimento, cuja elaboração foi subsidiada pelos resultados das atividades do Grupo de Trabalho Nacional Pró-Convivência Familiar e Comunitária (GT Nacional) e pelos debates em diversos espaços, incluindo-se as conferências estaduais e Nacional dos Direitos da Criança e do Adolescente realizadas em 2007. ${ }^{6}$ Naquele mesmo ano, o então Ministério do Desenvolvimento Social e Combate à Fome (MDS) - atual Ministério da Cidadania (MC) -, com a Fundação Oswaldo Cruz (Fiocruz) e o Ministério da Saúde (MS), deu início a um novo estudo que permitiu a identificação dos aspectos mais relevantes da estruturação da oferta dos serviços acolhimento: o Levantamento Nacional de Crianças e Adolescentes em Serviços de Acolhimento (Assis e Farias, 2013). Esse estudo, por sua vez, contribuiu para a construção de um processo de monitoramento dessas unidades via o Censo do Sistema Único de Assistência Social (Censo Suas) e a definição de diretrizes a serem adotadas no processo de reordenamento e regionalização da oferta desses serviços. ${ }^{7}$ O monitoramento do processo de expansão qualificada das unidades de acolhimento tem sido feito com base nas informaçóes coletadas no questionário do Censo Suas, preenchido anualmente por gestores estaduais e municipais da assistência social, com a finalidade de subsidiar o planejamento de açóes direcionadas aos serviços de acolhimento para crianças e adolescentes, bem como orientar o aperfeiçoamento da gestáo e da qualidade de serviços e benefícios socioassistenciais prestados à população como um todo.

Considerando o horizonte de implementação do plano de ação do PNCFC até 2015, ${ }^{8}$ a Secretaria Nacional de Assistência Social (SNAS), do MC, e a Secretaria Nacional dos Direitos da Criança e do Adolescente (SNDCA), do Ministério da Mulher, da Família e dos Direitos Humanos (MMFDH), iniciaram o planejamento de estratégias para a avaliação do Plano Nacional de Promoção, Proteção e Defesa do Direito de Crianças e Adolescentes à Convivência Familiar e Comunitária, com vistas à sua posterior atualizaçáo. Com o trabalho de outros atores, a parceria firmada entre a SNAS e o Ipea em 2019 tem permitido o desenvolvimento de açóes que integram a avaliação do plano, no sentido de consolidar os avanços obtidos, assim como atualizar as estratégias do PNCFC diante dos novos desafios para a garantia da convivência familiar e comunitária de crianças e adolescentes.

Este relatório visa contribuir com uma das dimensões dessa avaliação, a saber, $o$ reordenamento dos serviços de acolhimento e a implementação de novas modalidades de acolhimento (familias acolhedoras e repúblicas). Para tanto, a partir dos dados contidos no Censo Suas, analisa a estrutura e o funcionamento dos serviços de acolhimento institucional e dos serviços de acolhimento familiar (SAFs) para crianças e adolescentes,

6. Iniciado em 2005 por iniciativa do Fundo das Nações Unidas para a Infância (Unicef), com cooperação técnica da Associação Brasileira Terra dos Homens e apoio da Secretaria Especial dos Direitos Humanos - SEDH, do Instituto Camargo Corrêa e do Instituto C\&A, o GT Nacional reuniu representantes governamentais (estados e municípios) e não governamentais para a discussão e a proposição de parâmetros nacionais, com o objetivo de oferecer atendimento em serviços de acolhimento para crianças e adolescentes (Brasil, 2009, p. 17). Mais tarde o GT Nacional deu origem ao Movimento Nacional Pró-Convivência Familiar e Comunitária.

7. Resoluções CNAS no 23/2013 (reordenamento) e no 31/2013 (regionalização. Ver também as resoluções nos 15 e 17 da Comissão Intergestores Tripartite (CIT), de 5 de setembro e 3 de outubro de 2013.

8. 0 prazo definido para a implementação do Plano de Ação do PNCFC é de 2007 a 2015, o qual se desdobra em ações de curto prazo (2007-2008); médio prazo (2009-2011); longo prazo (2012-2015) e em ações permanentes (2007-2015). 
assim como das repúblicas para egressos dos serviços de acolhimento. A pesquisa dedica ainda uma seção ao perfil dos acolhidos nesses serviços. Por fim, discute como as análises realizadas podem subsidiar a atualização do PNCFC.

\section{PNCFC E OS SERVIÇOS SOCIOASSISTENCIAIS DE ACOLHIMENTO}

O PNCFC reconhece a necessidade de compreender a complexidade e a riqueza dos vínculos familiares e comunitários que podem ser mobilizados nas diversas frentes de defesa dos direitos de crianças e adolescentes. Foi estruturado com base em três dimensóes centrais que convergem para a garantia do direito à convivência familiar e comunitária: fortalecimento das políticas de apoio à família e prevençáo do afastamento do convívio familiar; reordenamento dos SAIs e implementação de novas modalidades de atendimento (famílias acolhedoras e repúblicas); e adoção centrada no superior interesse da criança e do adolescente.

O objetivo central do plano é fortalecer a rede de proteção social à família, de forma a prover-lhe o suporte necessário à criaçáo e à educaçáo das crianças e, portanto, o apoio para a manutenção do convívio. Também busca minimizar prejuízos decorrentes das situaçóes em que a separaçáo é inevitável, por meio do atendimento qualificado nos serviços de acolhimento e das medidas necessárias à promoção da retomada do convívio familiar - prioritariamente com a família de origem e, excepcionalmente, por meio da colocação em adoção. Entre suas diretrizes, destacam-se a centralidade da família nas políticas públicas; a primazia da responsabilidade do Estado no fomento de políticas integradas de apoio à família; o respeito à diversidade; ${ }^{9}$ o reconhecimento das competências da família na sua organização interna e na superação de suas dificuldades; o fortalecimento da autonomia da criança, do adolescente e do jovem adulto na elaboração do seu projeto de vida; o reordenamento dos programas de acolhimento institucional; e a garantia dos princípios de excepcionalidade e provisoriedade da medida protetiva de acolhimento de crianças e adolescentes, bem como a adoçáo centrada no interesse da criança e do adolescente (Brasil, 2006).

No caso do serviço de acolhimento, o PNCFC busca o cumprimento da garantia da excepcionalidade e provisoriedade da medida de acolhimento, o que vai ao encontro dos princípios contidos no art. 92 do ECA, ${ }^{10}$ com vistas à garantia do direito à convivência familiar e comunitária. Nesse sentido, o plano afirma, reiteradamente, a relação entre o reordenamento do serviço de acolhimento e a mudança de paradigma de cuidados:

Reordenar o atendimento significa reorientar as redes pública e privada, que historicamente praticaram o regime de abrigamento, para se alinharem à mudança de paradigma proposto. Este novo paradigma elege a família como a unidade básica da ação social e não mais concebe a criança e o adolescente isolados de seu contexto familiar e comunitário (Brasil, 2006, p. 72).

Tradicionalmente, os abrigos para crianças e adolescentes foram geridos pela assistência social, em especial pelas entidades filantrópicas e confessionais - hoje reconhecidas como

9. Étnico-cultural, identidade e orientação sexuais, equidade de gênero e particularidades das condições físicas, sensoriais e mentais. 10. "I - preservação dos vínculos familiares; II - integração em família substituta, quando esgotados os recursos de manutenção na família de origem; III - atendimento personalizado e em pequenos grupos; IV - desenvolvimento de atividades em regime de coeducação; $V$ - não desmembramento de grupos de irmãos; VI - evitar, sempre que possível, a transferência para outras entidades de crianças e adolescentes abrigados; VII - participação na vida da comunidade local; VIII - preparação gradativa para o desligamento; IX - participação de pessoas da comunidade no processo educativo" (Brasil, 1990, art. 92). 
organizaçóes da sociedade civil (OSCs) -, com foco tanto em protegê-las das ruas quanto defender a sociedade das consequências do seu abandono ${ }^{11}$ (Assis e Farias, 2013). Por sua vez, a modalidade de acolhimento familiar é mais recente, e, embora as primeiras experiências remontem à década de 1950, nas cidades de Porto Alegre e São Paulo, observa-se algum movimento pela sua expansão enquanto alternativa de acolhimento apenas na década de 1990 (Brasil, 2006).

Concomitante ao desenvolvimento da política de proteção à criança e ao adolescente deslanchada pela publicação do ECA, a assistência social passou, a partir da década de 1990, por um processo de construçáo da responsabilidade pública pela sua provisão protetiva, o que implicou redefiniçóes na organização e no conteúdo das suas ofertas, tendo como marcos institucionais a Lei Orgânica da Assistência Social - Loas (Lei no 8.742/1993) e a Política Nacional de Assistência Social - PNAS, em 2004, cujos princípios e diretrizes foram operacionalizados sob a forma do Sistema Único de Assistência Social (Brasil, 2005).

Vale registrar que a PNAS de 2004 foi o instrumento que atribuiu a responsabilidade de gerir os serviços de acolhimento ao Suas. A segurança de acolhida compóe o rol de garantias providas pela PNAS, referindo-se a açóes, cuidados, serviços e projetos operados por uma rede destinada a proteger crianças, adolescentes, jovens, adultos e idosos de situaçóes de abandono e isolamento e até mesmo famílias, preservando seus direitos e sua integridade física e psíquica e restaurando sua autonomia, seu protagonismo, suas aquisiçóes pessoais e suas possibilidades de convívio familiar e comunitário para além da oferta de atenção às necessidades básicas (condições materiais de abrigo, repouso, alimentação, higienização e vestuário).

A Tipificação Nacional dos Serviços Socioassistenciais (Resolução CNAS no 109/2009), por sua vez, contemplou no escopo da proteção especial de alta complexidade os serviços de acolhimento para diversos públicos, que têm como foco o atendimento de famílias e indivíduos que já se encontram em situação de risco social, tiveram direitos violados e que, por razóes diversas, não podem permanecer no convívio com a família de origem ou comunidade. Nesse nível de proteção, são enfrentadas situaçóes de abandono, maus tratos físicos e/ou psíquicos, abuso sexual e situação de rua. O acolhimento a crianças e adolescentes com vínculos familiares rompidos ou fragilizados visa, portanto, a proteção à criança e ao adolescente em múltiplas perspectivas (integridade física e psíquica, desenvolvimento integral, fortalecimento da autonomia e acesso a direitos como saúde e educação). Para tanto é que são adotadas medidas voltadas à retomada do convívio familiar - prioritariamente com a família de origem e, excepcionalmente, por meio da colocação em adoção.

Parte considerável do PNCFC ocupou-se do reordenamento dos serviços de acolhimento. No caso do acolhimento institucional, o plano indicou um conjunto de açóes a serem mobilizadas, como: a mudança na sistemática de financiamento das entidades de abrigo; ${ }^{12}$ a qualificação das(os) profissionais que trabalham nos serviços de acolhimento; o estabelecimento de indicadores qualitativos e quantitativos de avaliação dos programas; o

11. Esse era o paradigma que fundamentava a visão do Código de Menores de 1979. Com o ECA (Brasil, 1990), passou-se a vigorar o paradigma do superior interesse da criança e do adolescente. No que tange ao funcionamento dos serviços de acolhimento, tal orientação substitui a preocupação central de proteger a sociedade pela preocupação central de proteger a criança e o adolescente, seus direitos, seus interesses e seu desenvolvimento integral.

12. Eliminando-se formas que poderiam incentivar a manutenção desnecessária de crianças e adolescentes nas instituições - como 0 financiamento por criança e adolescente atendido - e incluindo-se recursos para o trabalho com a reintegração à família de origem. 
desenvolvimento de metodologias para o trabalho com famílias; a ênfase na prevenção do abandono e na potencialização das competências da família; a adequaçáo do espaço físico e do número de crianças e adolescentes atendidas(os) em cada unidade; o ajuste do espaço físico às normas de acessibilidade; e a articulaçáo de serviços de acolhimento com a rede de serviços, considerando todo o SGDCA (Brasil, 2006, p. 72-73).

No que tange à articulação dos serviços de acolhimento com a rede de serviços, o PNCFC prescreveu uma série de objetivos, dentre os quais destacamos a prevençáo, preservação e fortalecimento dos vínculos familiares dos acolhidos com a família de origem, com vistas à sua reconstruçáo e mudança de práticas de violação e para a reconstruçáo das relaçóes familiares; o acompanhamento das famílias, das crianças e dos adolescentes no processo de reintegração familiar; a articulação permanente com a Justiça da Infância e da Juventude evitando-se o prolongamento desnecessário da permanência no serviço de acolhimento; e, excepcionalmente, nos casos de encaminhamento para adoçáo, intervençáo qualificada para a aproximação gradativa e a preparaçáo prévia da criança, do adolescente e dos pretendentes, bem como acompanhamento - no período de adaptação dos adotantes e adotandos - por equipe interprofissional, preferencialmente da Justiça da Infância e da Juventude, em parceria com grupos de apoio à adoçáo e profissionais do serviço de acolhimento (Brasil, 2006, p. 72-73).

O PNCFC previu também o fomento e a parametrização ${ }^{13}$ da implementação de programas de famílias acolhedoras - ou acolhimento familiar -, como alternativa ao acolhimento institucional de crianças e adolescentes que necessitam ser temporariamente afastados da família de origem (Brasil, 2006).

Esse conjunto de diretrizes, objetivos e açôes voltados para o reordenamento dos serviços de acolhimento ganhou forma e conteúdo em diversos regulamentos do Suas.

O documento Orientaçóes Técnicas: serviços de acolhimento para crianças e adolescentes (Brasil, 2009), objeto da Resolução Conjunta CNAS/Conanda no 01/2009, fornece orientaçóes metodológicas ${ }^{14}$ e parâmetros de funcionamento ${ }^{15}$ de suas diversas modalidades de oferta, em especial no que tange ao acolhimento institucional (abrigos e casas-lares), ao acolhimento familiar (família acolhedora), a serviços de repúblicas para jovens, além de orientaçóes sobre a regionalização do atendimento. São justamente os parâmetros definidos nas Orientaçóes Técnicas (2009) que orientam a análise objeto deste relatório.

O reordenamento dos serviços de acolhimento para crianças e adolescentes foi deflagrado por meio da Resolução CNAS no 23/2013, que estabeleceu critérios de elegibilidade e partilha dos recursos do cofinanciamento federal para expansão qualificada destes nos

13. Por ocasião da elaboração do PNCFC, existiam mais de cinquenta municípios no país que desenvolviam programas de famílias acolhedoras, concentrados nas regiões Sul e Sudeste. Segundo o próprio PNCFC, não havia naquela época uma homogeneidade no funcionamento desses programas e alguns ainda estavam mais voltados para colocação em família substituta do que para o resgate dos laços com a família de origem (Brasil, 2006, p. 68).

14. Elaboração de estudo diagnóstico e de plano de atendimento individual e familiar; realização de acompanhamento da família de origem; articulação intersetorial; e execução de projeto político-pedagógico e de atividades de gestão do trabalho e de educação permanente dos profissionais que atuam na oferta dos serviços.

15. Características, público-alvo, aspectos físicos e jurídico-normativos, recursos humanos, infraestrutura e espaços mínimos sugeridos. 
municípios e no Distrito Federal (DF). ${ }^{16}$ Esse processo, que trouxe significativo incremento do cofinanciamento com alteração do valor de referência, visou superar fragilidades observadas na oferta do serviço de acolhimento, tais como condiçóes pouco adequadas de habitabilidade, salubridade e privacidade; capacidade de atendimento superior ao recomendado; equipe profissional em quantidade e formação insuficientes; alta rotatividade dos cuidadores, dificultando o estabelecimento de vínculos com as crianças/adolescentes; e ambiente distante do "familiar".

Por sua vez, as diretrizes para regionalização da oferta desse serviço, objeto da Resoluçáo CNAS no 31/2013, visaram garantir a universalizaçáo do acesso e a integralidade da oferta dos serviços assistenciais aos cidadãos em todo o país, implementada sob coordenação dos governos estaduais, de modo a atender especialmente a municípios de pequeno porte, cuja demanda e condiçôes de gestão dificultem a implementação de serviços de acolhimento locais.

\section{METODOLOGIA}

O estudo realizado tem natureza quantitativa, adotando como base teórica tanto os parâmetros definidos no documento Orientaçóes Técnicas: serviços de acolhimento para crianças e adolescentes (Brasil, 2009), descrito anteriormente, quanto as resoluçóes que promoveram o reordenamento e a regionalização desses serviços.

Adotaram-se como fontes de dados secundários as principais pesquisas já realizadas sobre o tema dos serviços de acolhimento, entre as quais destacamos duas em especial - o Levantamento Nacional dos Abrigos para Crianças e Adolescentes da Rede de Serviços de Ação Continuada - SACs ${ }^{17}$ (Silva, 2004) e o Levantamento Nacional de Crianças e Adolescentes em Serviços de Acolhimento (Assis e Farias, 2013). A pesquisa analisada por Enid Silva (2004) buscou conhecer as características dos serviços prestados pelas instituiçóes beneficiadas no âmbito dos SACs do MDS, que desenvolviam programas de abrigo para crianças e adolescentes à época. Abrangeu mais de 20 mil crianças e adolescentes acolhidos em 589 abrigos. que responderam ao questionário que foi a campo em 2003. Seus achados foram muito importantes para a subsidiar a elaboração do PNCFC em 2006, assim como para as reflexôes que mais tarde contribuiriam para a elaboração dos parâmetros expressos nas Orientaçóes Técnicas sobre os serviços de acolhimento de crianças e adolescentes (Brasil, 2009). Posteriormente, o MDS promoveu, com a Fiocruz/MS, uma pesquisa mais ampla, que foi a campo em 2010 e envolveu 2.624 SAIs e 144 SAFs distribuídos em território nacional (Assis e Farias, 2013). Participaram desse levantamento nacional 2.624 SAIs, dispersos em 1.157 municípios brasileiros (20,8\% dos 5.570 existentes), localizados nas 27 Unidades da Federação (UFs). Nos SAIs pesquisados, havia 36.929 crianças e adolescentes acolhidos de um total de 52.587 vagas.

16. A expansão qualificada consiste na implantação de novos serviços de acolhimento de acordo com os novos parâmetros, enquanto 0 reordenamento é um processo gradativo de qualificação e adequação das unidades existentes. 0 reordenamento e a expansão qualificada visavam aos municípios que possuíam população igual ou superior a 50 mil habitantes e sede de Comarca e que ainda não contavam com a oferta do serviço; aos municípios com população superior a 20 mil, caso já tivessem formalizado o aceite de implantação do Creas; e os municípios com população inferior a 20 mil, mas que recebiam cofinanciamento do Piso Alta Complexidade I e que tinham formalizado 0 aceite de implantação do Cras.

17. Em tabelas e gráficos apresentados neste relatório, utilizaremos levantamento nacional para identificar o uso dos dados da pesquisa. 
Em sua maioria, ${ }^{18}$ os dados analisados são provenientes do Censo Suas (2012-2018), cujos questionários - dirigidos a todas as unidades da rede que executam os serviços de acolhimento - versam sobre estrutura física, características e atividades executadas pelos serviços, bem como sobre o perfil dos profissionais que atuam nos serviços de acolhimento. A principal base utilizada refere-se a serviços de acolhimento e traz informaçóes sobre aqueles que atendem crianças e adolescentes e repúblicas para jovens egressos de serviços de acolhimento, ${ }^{19}$ cujas informaçóes têm sido coletadas de maneira mais aprofundada desde 2012, sendo de 2018 os últimos dados disponíveis na data de elaboração deste relatório. Até 2014, algumas informaçóes sobre os serviços de acolhimento em família acolhedora eram coletadas nos questionários aplicados às gestóes municipais e estaduais, o que pode explicar as flutuaçóes entre os dados de 2012 a 2014, com um pico de acolhidos e vagas em 2012 (tabela 1), o que pode indicar maior imprecisão nas informaçóes coletadas ao longo desses anos. Todavia, a partir de 2015, essa modalidade passou a ser investigada de maneira mais aprofundada no Censo Suas Acolhimento e, a partir de 2017, passou a contar com questionário próprio (Censo Suas - Família Acolhedora).

Em se tratando das repúblicas, vale apontar que até 2015 não havia uma opção específica de modalidade de acolhimento repúblicas para jovens de preenchimento exclusivo para unidades que afirmavam atender como público jovens egressos de serviços de acolhimento. Isso fazia com que algumas unidades que não se caracterizavam como repúblicas para esses jovens egressos respondessem como tal. A restrição do preenchimento e a criaçáo de categoria que remetesse especificamente às repúblicas para jovens tornaram mais precisa a identificação dessas unidades. A análise aqui apresentada utiliza os dados das unidades que se identificaram como esse tipo de modalidade em $2018 .^{20}$

Vale ressaltar que a elaboração dos questionários do Censo Suas (acolhimento e família acolhedora) se baseia fortemente nas duas pesquisas referenciadas neste documento, assim como nas normativas existentes a respeito do acolhimento de crianças e adolescentes. Por isso, sempre que possível, buscou-se produzir indicadores compatíveis ou que dialogassem com os estudos indicados, de maneira a verificar a trajetória e os avanços na oferta dos serviços de acolhimento, a partir das mudanças institucionais ocorridas na última década. Por conta da menor abrangência de unidades na amostra, optamos por excluir os dados de 2003 dos gráficos. Quando necessário, estes serão mencionados na análise, de modo a qualificar o histórico do serviço.

As unidades de análise variam segundo o parâmetro analisado, ora se referindo a SAIs ou SAFs, ora a vagas oferecidas ou acolhidos nos serviços de acolhimento. No que diz respeito aos acolhidos, apresentamos em parte das análises o número total de acolhidos da unidade, que nem sempre são apenas crianças e adolescentes, uma vez que, entre os acolhidos em SAIs, foram encontrados adultos. ${ }^{21}$

\footnotetext{
18. Para estimativas de população foram usados os dados municipais do Censo Demográfico 2010 por coorte de idade, atualizando-se os índices pelas estimativas populacionais municipais anuais divulgadas pelo Instituto Brasileiro de Geografia e Estatística (IBGE).

19. Unidades que se identificam como atuando na modalidade repúblicas, que têm como público atendido jovens entre 18 e 21 anos egressos de outros serviços de acolhimento.

20. A caracterização apenas de público para identificação das unidades, como utilizado nos casos dos serviços voltados para crianças e adolescentes, se mostrou imprecisa o caso dos jovens egressos de outros serviços de acolhimento. Isso se dá na medida em que serviços que não se caracterizam como repúblicas para jovens egressos - assim como definido na Tipificação Nacional dos Serviços Socioassistenciais e outras normativas, como o próprio PNCFC - respondiam como tal.

21. Em 2018, 3,87\% dos acolhidos possuíam 18 anos ou mais. Via de regra, esses adultos costumam ser jovens que recém completaram a maioridade ou pessoas com deficiência que entram nos acolhimentos quando crianças e adolescentes, e que, por falta de rede para seu encaminhamento, acabam por permaneceram nestas unidades.
} 
Dado que um dos objetivos do trabalho é identificar os resultados do reordenamento na provisão dos serviços de acolhimento, assim como a maneira pela qual as unidades têm promovido a convivência familiar e comunitária, entendeu-se importante apresentar dados para o período anterior à vigência das normativas - publicadas em 2013 - que buscam promovê-lo. Os dados do levantamento feito em 2010 cumprem essa funçáo. Os dados de 2012 foram trazidos para compor os indicadores que não puderam ser comparáveis à investigação de 2010. Quando disponíveis, para além dos dados de 2010 e 2012, são apresentados também dados de 2014 - período de implantação da resolução supracitada -, 2016 e $2018 .^{22}$

Por fim, esclarecemos que, para além de apresentar e comentar os resultados encontrados, sugerimos ao longo do texto algumas possibilidades explicativas destes, formuladas a partir das experiências tanto dos(as) pesquisadores(as) e autores(as), como das técnicas da SNAS consultadas na elaboração deste relatório, as quais se encontram envolvidas na gestão federal da política. Cabe ressaltar que o intuito de divulgar tais hipóteses explicativas foi apenas problematizar eventuais desafios a serem enfrentados na atualização do PNCFC, e de forma alguma esgotam-se as múltiplas perspectivas pelas quais podem ser analisados os resultados da política no período analisado.

Na tabela 1, apresentamos em linhas gerais algumas informações das pesquisas utilizadas.

TABELA 1

Informações gerais sobre as bases de dados analisadas

\begin{tabular}{|c|c|c|c|c|c|c|c|c|}
\hline \multirow{2}{*}{ Ano } & \multicolumn{8}{|c|}{ Serviços de acolhimento institucional } \\
\hline & 2010 & 2012 & 2013 & 2014 & 2015 & 2016 & 2017 & 2018 \\
\hline Número de serviços & 2.624 & 2.360 & 2.464 & 2.791 & 2.821 & 2.866 & 2.834 & 2.877 \\
\hline Municípios ${ }^{1}$ & 1.157 & 1.231 & 1.295 & 1.505 & 1.592 & 1.630 & 1.654 & 1.710 \\
\hline Vagas & 52.587 & 48.654 & 48.845 & 54.479 & 52.829 & 51.353 & 49.111 & 50.646 \\
\hline \multirow[t]{2}{*}{ Acolhidos $^{2}$} & 37.362 & 34.940 & 34.014 & 35.525 & 33.200 & 32.592 & 31.769 & 31.640 \\
\hline & \multicolumn{8}{|c|}{ Serviços de acolhimento familiar ${ }^{3}$} \\
\hline Número de serviços & 144 & - & - & - & 133 & 167 & 272 & 333 \\
\hline Municípios ${ }^{1}$ & 132 & 368 & 372 & 315 & 119 & 151 & 253 & 316 \\
\hline Famílias cadastradas & 791 & 2.664 & 1.364 & 1.433 & 2.008 & 1.422 & 1.342 & 1.629 \\
\hline \multirow[t]{2}{*}{ Acolhidos } & 932 & 2.346 & 1.390 & 1.770 & 962 & 1.107 & 3.316 & 1.392 \\
\hline & \multicolumn{8}{|c|}{ Serviços de acolhimento institucional - república para jovens egressos ${ }^{4}$} \\
\hline Número de serviços & - & 7 & 10 & 15 & 16 & 23 & 25 & 30 \\
\hline Municípios ${ }^{1}$ & - & 4 & 8 & 12 & 13 & 18 & 19 & 19 \\
\hline Vagas & - & 76 & 112 & 147 & 165 & 284 & 204 & 244 \\
\hline Acolhidos & - & 41 & 59 & 71 & 80 & 125 & 101 & 152 \\
\hline
\end{tabular}

Fontes: Levantamento Nacional, 2010; e Censo Suas 2012, 2013, 2014, 2015, 2016, 2017 e 2018.

Notas: ${ }^{1}$ Com ao menos um serviço de acolhimento.

${ }^{2}$ Todos acolhidos dos serviços nas modalidades crianças/adolescentes e crianças/adolescentes com deficiência, sem recorte de idade de 0 a

17 anos.

3 Os dados do Serviço de Família Acolhedora relativos ao número de municípios e número de crianças acolhidas para 2012, 2013 e 2014 foram coletados pelos questionários voltados para as gestões municipais e estaduais.

${ }^{4}$ Para os dados de 2012 a 2015 do Censo Suas, foram selecionados para a análise os serviços que se definiram como tendo como público jovens egressos de serviços de acolhimento que se declararam na modalidade repúblicas. Entre 2016 e 2018, foram escolhidos os que afirmaram serem repúblicas para jovens. 


\section{COBERTURA, MODALIDADES E NATUREZA DOS SERVIÇOS DE ACOLHIMENTO}

Os serviços analisados oferecem acolhimento provisório para crianças e adolescentes determinados por medida protetiva de acolhimento institucional (Brasil, 1990, art. 101, $\$$ VII) - forma mais tradicional de organização do serviço - ou familiar (Brasil, 1990, art. 101, $\mathbb{S}$ VIII) - modalidade mais recente já prevista na PNAS, em 2004, e no PNCFC, em 2006, mas somente reconhecida pelo ECA a partir de 2009, por meio da Lei oㅜ 12.010/2009.

Desenvolvidos a partir das diretrizes do PNCFC, retomamos aqui os marcos mais importantes para a expansão qualificada (criação de novos serviços) e o reordenamento dos serviços de acolhimento para crianças e adolescentes (adequação dos que já existem), como descrito a seguir.

1) A Tipificação Nacional dos Serviços Socioassistenciais (Resolução CNAS no 13 , de 13 de maio de 2014), que padronizou os serviços de proteção social básica e especial, estabelecendo seus conteúdos essenciais, o público a ser atendido, o propósito de cada um destes e os resultados esperados para a garantia dos direitos socioassistenciais.

2) O documento Orientaçôes Técnicas: Serviços de Acolhimento para Crianças e Adolescentes (Brasil, 2009), que definiu modalidades e parâmetros para o funcionamento dos serviços.

3) A Resolução CNAS no 23/2013 sobre o reordenamento dos serviços de acolhimento para crianças e adolescentes, a qual definiu os critérios de elegibilidade e partilha dos recursos para cofinanciamento federal.

4) A Resolução CNAS no 31/2013 sobre a regionalização dos serviços de acolhimento para crianças e adolescentes, a qual definiu critérios para expansão qualificada desses serviços, em especial no caso dos municípios de menor porte náo contemplados na portaria do reordenamento.

Como sinalizado anteriormente, tais normativas convergem com objetivos, açóes e metas previstas no PNCFC e, enquanto tal, produziram um movimento que, aos poucos, vem reconfigurando a oferta dos serviços de acolhimento para crianças e adolescentes, tanto na sua modalidade institucional (SAI) quanto familiar (SAF).

A seguir, recuperamos essa trajetória com foco em três unidades de análise; quais sejam: serviços de acolhimento (SAI e SAF), vagas e acolhidos.

\subsection{Cobertura de serviços de acolhimento}

Esta subseção aborda a cobertura dos serviços de acolhimento de crianças e adolescentes em nível nacional e regional, segundo indicadores já adotados no monitoramento da política. Apesar de desde 2009 o ECA estabelecer a preferência do acolhimento em programas de acolhimento familiar em detrimento do acolhimento institucional, ${ }^{23}$ constata-se que a maior parte da oferta tem se dado na forma institucional. 
Os gráficos 1, 2 e 3 ilustram, em nível nacional, a trajetória tanto do SAF quanto do SAI. Observam-se variaçóes segundo os parâmetros analisados (serviços, vagas ou número de acolhidos), mas a dinâmica de predominância do modelo institucional permanece ao longo de todo o período.

GRÁFICO 1

Trajetória dos serviços de acolhimento para crianças e adolescentes - Brasil

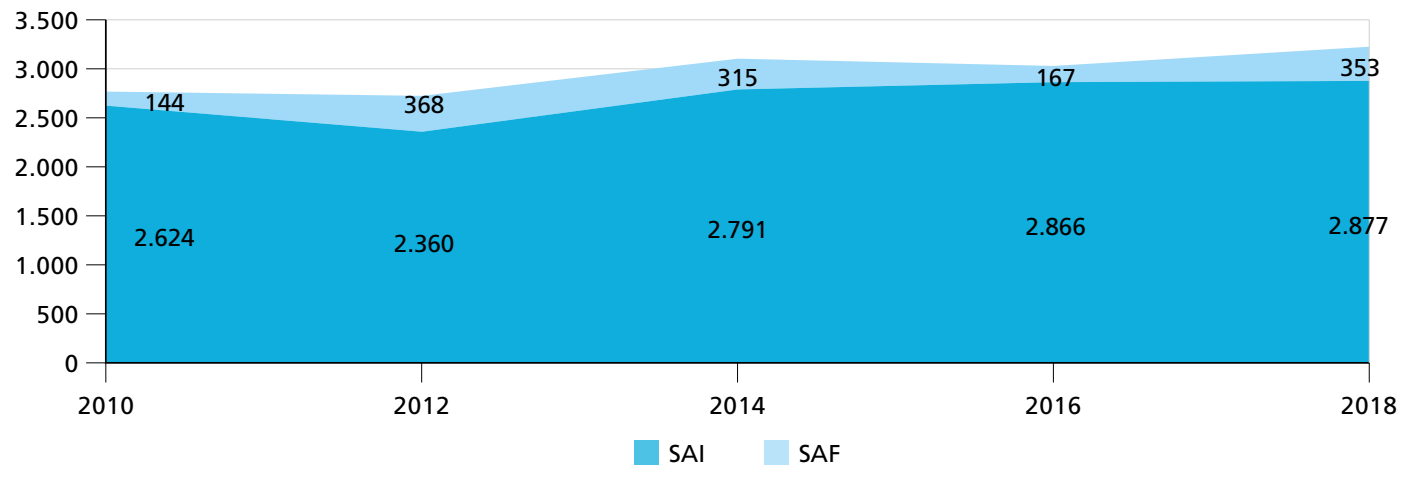

Fontes: Levantamento Nacional, 2010; e Censo Suas 2012, 2014, 2016 e 2018.

Nota-se também ampliação gradual da quantidade de serviços. O ano de 2012 parece ter sido marcado pela expansão do acolhimento familiar e pela redução da oferta de SAIs, mas a mudança na fonte de $\operatorname{dados}^{24}$ e a própria variância no número de SAFs ao longo dos anos sugerem cautela na inferência. A partir de entáo, a quantidade de SAIs cresce ano após ano. Esse crescimento provavelmente respondeu aos incentivos criados pela Resolução CNAS no 23/2013, que estabeleceu novas regras de cofinanciamento para a expansão qualificada e o reordenamento institucional. Em outubro de 2013, também foram publicadas as Resoluçóes CNAS no 31 e CIT no 17, que aprovaram os princípios e as diretrizes para regionalizaçáo no âmbito do Suas e dos serviços de acolhimento de crianças, adolescentes e jovens até 21 anos, como também os critérios de elegibilidade e partilha dos recursos do cofinanciamento federal.

\section{GRÁFICO 2}

Trajetória de vagas nos serviços de acolhimento para crianças e adolescentes - Brasil

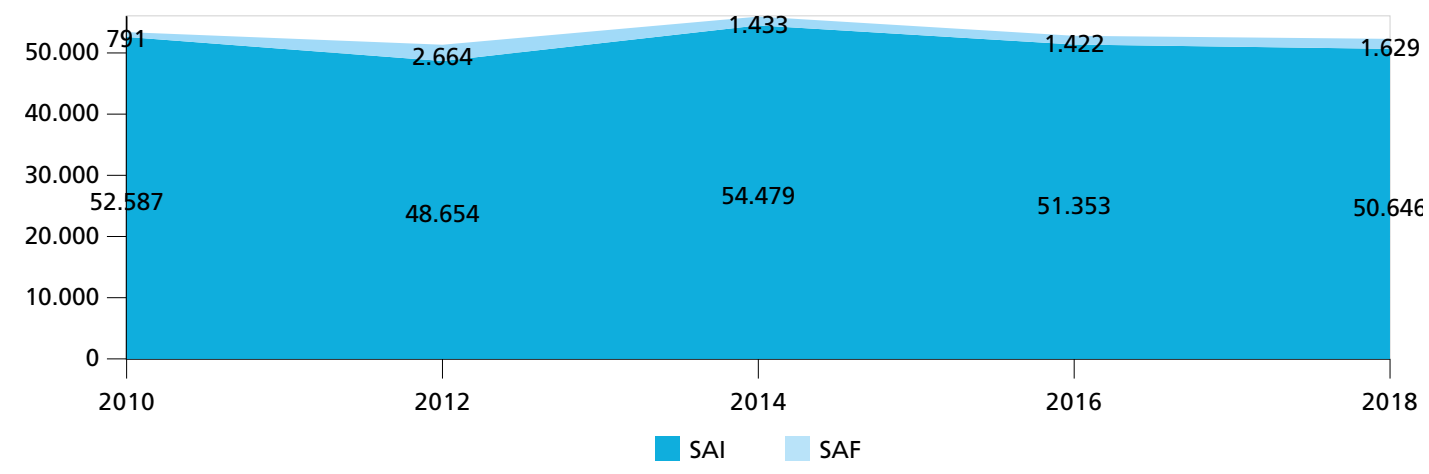

Fontes: Levantamento Nacional, 2010; e Censo Suas 2012, 2014, 2016 e 2018.

24. A linha de base adotada, de 2010, tem uma fonte diferente dos demais anos analisados. A inflexão observada em 2012 poderia, em tese, refletir apenas a eventual subnotificação decorrente do grau de aderência dos gestores nos primeiros anos de coleta do questionário Censo Suas para serviços de acolhimento. 
De forma geral, chama atenção o quanto oscila, ao longo dos anos, a capacidade instalada para oferta do serviço no território nacional. O pico da oferta de vagas ocorre em 2014, reduzindo-se gradualmente a partir de então. Essa oscilação pode estar associada às diversas iniciativas (ampliação do cofinanciamento, definição de parâmetros de oferta e regionalizaçáo) veiculadas nos anos anteriores. $\mathrm{O}$ aumento relativo de vagas de acolhimento familiar verificado em 2012 também pode indicar um esforço de ampliação decorrente da sua priorizaçáo no ECA pela Lei nº 12.010/2009.

\section{GRÁFICO 3}

Trajetória do número de acolhidos nos serviços de acolhimento para crianças e adolescentes - Brasil

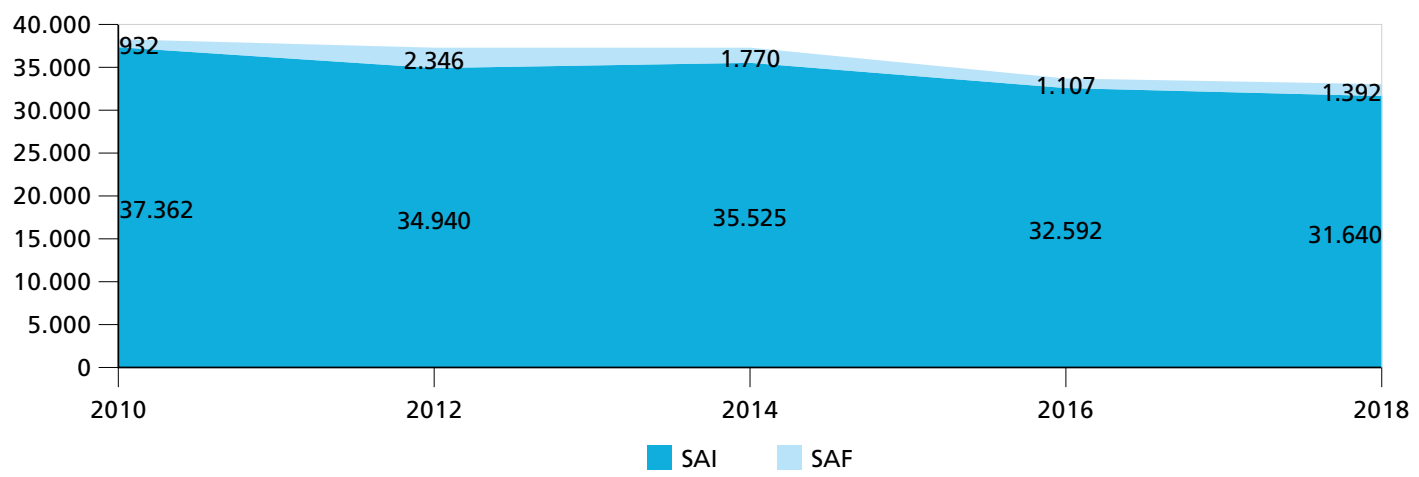

Fontes: Levantamento Nacional, 2010; e Censo Suas 2012, 2014, 2016 e 2018

Por fim, o total de crianças e adolescentes acolhidos em SAIs e SAFs reduz-se gradualmente em todo o período analisado. Cotejado com a ampliaçáo de vagas e serviços observadas nos gráficos anteriores, isso sugere que, para além das variaçóes ressaltadas, temos uma tendência à maior moderação no uso dessa medida protetiva. Esse resultado vai ao encontro das diretrizes da sua excepcionalidade e provisoriedade, além do atendimento em pequenos grupos, preconizados pelo ECA e demais regulamentos da política.

\subsubsection{Taxas de acolhimento e vagas por 100 mil habitantes ( 0 a 17 anos), em SAls}

O governo brasileiro adotou um indicador que mede a incidência do serviço de acolhimento de crianças e adolescentes para monitorar uma das metas nacionais dos Objetivos do Desenvolvimento Sustentável (ODS) da ONU; ${ }^{25}$ qual seja, a taxa de acolhidos para cada 100 mil pessoas na faixa etária de 0 a 17 anos.

Na tabela 2, que considera apenas o SAI, ${ }^{26}$ mensuramos a incidência do serviço segundo o referido indicador, cuja taxa passou de 65,6, em 2010, para 59,1, em 2018; queda de 9,9\%. Observa-se ao longo do período analisado diminuição das desigualdades regionais nesse aspecto, com redução importante na taxa de acolhidos na região Sudeste $(-25,7 \%)$, acompanhada de aumento relativo também importante nas regióes Norte $(+51,4 \%)$ e Nordeste $(+38,5 \%)$.

25. ODS 16: Promover sociedades pacíficas e inclusivas para o desenvolvimento sustentável, proporcionar o acesso à justiça para todos e construir instituições eficazes, responsáveis e inclusivas em todos os níveis e meta 16.2: Acabar com abuso, exploração, tráfico e todas as formas de violência e tortura contra crianças.

26. Tendo-se em vista a implementação ainda incipiente do acolhimento familiar (SAF) diante do SAI - os acolhidos em SAFs representam apenas $4,2 \%$ do total de crianças e adolescentes acolhidos no país -, esse serviço será objeto de análise específica mais adiante. 
TABELA 2

Acolhidos em SAls, por 100 mil habitantes (0 a 17 anos) - Brasil e Grandes Regiões

\begin{tabular}{lcccccc}
\hline Grandes Regiões & 2010 & 2012 & 2014 & 2016 & 2018 & $\begin{array}{c}\text { Variação } \\
(\%)\end{array}$ \\
\hline Centro-Oeste & 50,2 & 56,5 & 59,9 & 57,6 & 56,4 & 12,3 \\
Nordeste & 21,5 & 29,6 & 26,3 & 28,1 & 29,8 & 38,5 \\
Norte & 17,6 & 23,5 & 25,2 & 25,2 & 26,7 & 51,4 \\
Sudeste & 101,4 & 77,5 & 84,2 & 78,4 & 75,3 & $-25,7$ \\
Sul & 112,4 & 110,3 & 113,6 & 109,0 & 107,1 & $-4,7$ \\
Brasil & $\mathbf{6 5 , 6}$ & $\mathbf{5 9 , 6}$ & $\mathbf{6 2 , 0}$ & $\mathbf{5 9 , 9}$ & $\mathbf{5 9 , 1}$ & $\mathbf{- 9 , 9}$ \\
\hline
\end{tabular}

Fontes: IBGE (2020) - disponível em: <https://bit.ly/35lad2t> e <https://bit.ly/30o2EQ1>, acesso em: 3 jun. 2020; Censo Demográfico 2010; PNAD Contínua 2012, 2014, 2016 e 2018; Levantamento Nacional, 2010; e Censo Suas 2012, 2014, 2016 e 2018.

Enquanto a variável número de acolhidos mede a incidência dos acolhimentos, a variável número de vagas diz respeito à capacidade instalada nos municípios para fazer frente à demanda de acolhimentos. São, portanto, olhares diferentes sobre sua cobertura no território.

A capacidade dos serviços de acolhimento, a ser cofinanciada pelo governo federal, é calculada com base na razão de 0,5 vagas por 1 mil crianças e adolescentes na populaçáo da localidade (art. 11, $\$ 4^{\circ}$, Resoluçáo CNAS no 23/2013) ${ }^{27}$ Seguindo-se o referido parâmetro, e adotando-se a escala do indicador da meta 16.2 dos três ODS para facilitar a comparaçáo, é desejável que cada localidade tenha capacidade de atendimento de cinquenta vagas para cada 100 mil crianças e adolescentes.

A tabela 3 revela que a média brasileira supera em muito esse patamar em todo o período analisado, variando de 93,4 , em 2010, para 98,5, em 2018, ampliação de 5,5\%. As regióes Sul e Sudeste já estavam bem acima do parâmetro definido desde o início da série, e, embora com alguma redução $(-8,8 \%)$ na região Sul, essas ainda são as regióes com maior oferta de vagas. Vale registrar a importante melhoria relativa desse indicador nas demais regióes, em especial na regiáo Norte $(+51,2 \%)$, o que a permitiu superar a capacidade definida pela normativa federal já em 2014. A região Nordeste, por sua vez, alcançou essa meta em 2016, ao registrar 50,1 vagas por 100 mil habitantes ( 0 a 17 anos).

TABELA 3

Vagas em SAls por 100 mil habitantes (0 a 17 anos) - Brasil e Grandes Regiões

\begin{tabular}{lrrrrrc}
\hline Grandes regiões & 2010 & 2012 & 2014 & 2016 & 2018 & $\begin{array}{c}\text { Variação } \\
(\%)\end{array}$ \\
\hline Centro-Oeste & 102,0 & 85,9 & 110,6 & 111,8 & 120,4 & 18,1 \\
Nordeste & 41,3 & 46,1 & 47,6 & 50,1 & 49,8 & 20,6 \\
Norte & 35,4 & 43,4 & 51,1 & 51,7 & 53,6 & 51,2 \\
Sudeste & 119,0 & 112,0 & 130,9 & 122,4 & 121,4 & 2,0 \\
Sul & 182,7 & 154,6 & 175,3 & 167,4 & 166,7 & $-8,8$ \\
Brasil & $\mathbf{9 3 , 4}$ & $\mathbf{8 7 , 8}$ & $\mathbf{1 0 1 , 0}$ & $\mathbf{9 8 , 1}$ & $\mathbf{9 8 , 5}$ & $\mathbf{5 , 5}$ \\
\hline
\end{tabular}

Fontes: IBGE (2020); Censo Suas 2012, 2014, 2016 e 2018; e Levantamento Nacional, 2010.

Obs.: 0 número de vagas por 100 mil habitantes é calculado por meio da fórmula: número de vagas ofertadas no município multiplicado por 100.000 e, em seguida, dividido pela estimativa da população de 0 a 17 anos nessa localidade. Para a definição da estimativa, foram usados os dados municipais do Censo Demográfico 2010 por coorte de idade, atualizando-se os índices pelas estimativas populacionais municipais anuais divulgadas pelo IBGE.

27. Vale ressaltar que a taxa de vagas definida como parâmetro do reordenamento foi fixada tendo vista a capacidade instalada em 2012 e, portanto, funciona como uma proxy da demanda considerando que os dados disponíveis não permitem identificar a distância entre uma "demanda real" e essa proxy. 
O mapa 1 mostra o desempenho de cada UF nessa mesma taxa. Vale destacar que Rondônia, apesar de encontrar-se na regiáo Norte - que tem a menor oferta de vagas -, possui desempenho próximo ao dos estados com melhor desempenho, localizados no Sul, no Sudeste e no Centro-Oeste do país. A maior parte dos estados (dezessete) possui oferta inferior à média nacional $(98,5)$. Destes, seis estados do Norte e do Nordeste (Amazonas, Pará, Maranhão, Piauí, Rio Grande do Norte e Paraíba) apresentam oferta de vagas inferior a cinquenta, parâmetro fixado pelo Suas.

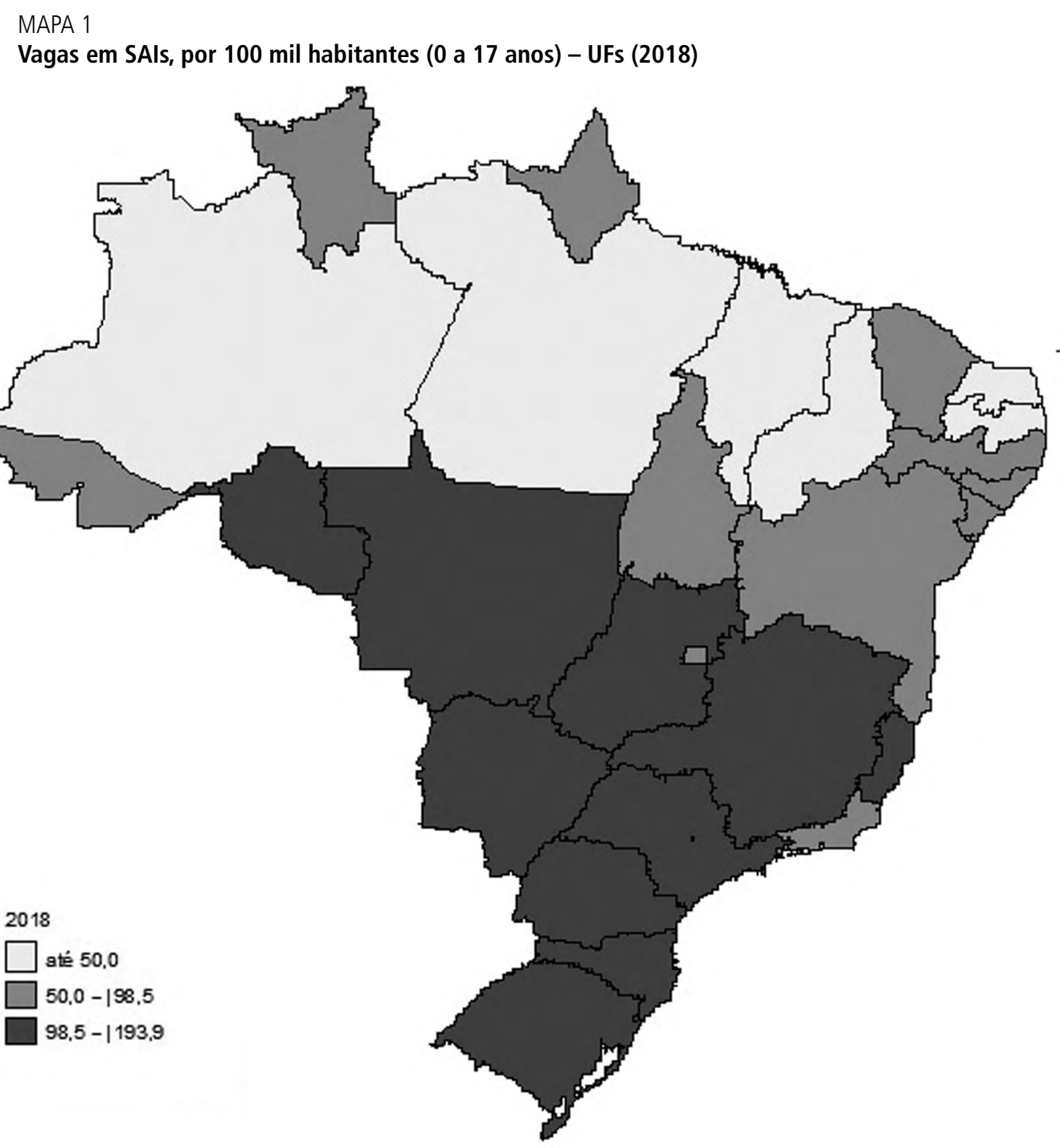

Fonte: Censo Suas Acolhimento 2018

Obs.: Mapa reproduzido em baixa resolução em virtude das condições técnicas dos originais (nota do Editorial).

É possível ainda analisar a cobertura da oferta de vagas no nível municipal. Dos 1.710 municípios cujas gestóes da política de assistência social informaram sobre os SAIs em 2018, apenas $56(3,3 \%)$ possuem oferta inferior a 50 por 100 mil habitantes ( 0 a 17 anos). Ou seja, via de regra, o serviço, quando existe, oferece cobertura segundo os patamares definidos no 
processo de reordenamento. Cinco metrópoles ${ }^{28}$ ofertam vagas em quantidade inferior ao patamar regulamentado. Do restante dos municípios nessa situação, mais da metade (36) são de grande porte, distribuídos em todas as regiôes do país.

Em que pesem as limitaçóes apontadas em ambos os indicadores de cobertura dos SAIs, os movimentos em números de acolhidos e de vagas ofertadas evidenciam dinâmicas regionais bem distintas. A queda na taxa de acolhidos da regiáo Sudeste $(-25,7 \%)$ (tabela 2) sugere um avanço na aplicação do caráter excepcional e provisório do acolhimento institucional, considerando-se o aumento apenas discreto das vagas disponíveis (2\%) (tabela 3). Ao mesmo tempo, a ampliação da taxa de vagas nas regiôes Norte $(+51,2 \%)$ e Nordeste $(+20,6 \%)$ (tabela 3) parece ter suprido uma demanda reprimida pelo serviço, uma vez que a taxa de acolhidos também aumentou substancialmente em ambas as regióes (+ 51,4\% na região Norte e $+38,5 \%$ na região Nordeste) (tabela 2 ).

\subsubsection{Distribuição regional dos serviços de acolhimento, acolhidos e vagas em SAls}

A tabela 4 apresenta a evolução do número de serviços, vagas ofertadas e número de crianças e adolescentes acolhidos em SAIs, entre 2010 e 2018. Nesse período, ampliou-se o número total de SAIs em funcionamento (+9,6\%), o que significou 253 unidades a mais que o início da série analisada. Por sua vez, observa-se redução no número de vagas $(-3,7 \%$, ou menos 1.992 vagas), com diminuição ainda mais importante $(-15,3 \%)$ no número de crianças e adolescentes acolhidos (-5.722). Esses resultados (ampliação do número de SAIs concomitante à redução do número de vagas e, principalmente, de acolhidos) vão ao encontro das diretrizes do acolhimento institucional, que prevê o acolhimento em pequenos grupos e unidades menores, ao permitir atenção mais individualizada e personalizada aos acolhidos, bem como proporcionar o funcionamento mais semelhante a uma família, ainda que as crianças e os adolescentes vivam em instituiçóes.

O balanço da série histórica revela que o processo de reordenamento institucional ampliou a oferta de serviços a partir de unidades menores e, aparentemente, mais adequadas para o atendimento em pequenos grupos. Observa-se que a quantidade de SAIs aumentou em todas as regióes; porém, a relação vagas-SAIs diminuiu a partir de 2014, demonstrando que as novas unidades de acolhimento foram criadas para atender um número menor de crianças e adolescentes.

Além disso, com exceção da região Nordeste, que manteve praticamente inalterado o número de acolhidos, a partir de 2014 todas as demais regióes se reduziram nesse quesito. Trata-se de indicativo de que, ao lado do processo de reordenamento institucional, se buscou também cumprir os princípios da excepcionalidade e da provisoriedade da medida de afastamento do convívio familiar. 
TABELA 4

Número de unidades e acolhidos e média de vagas - Brasil e Grandes Regiões

\begin{tabular}{|c|c|c|c|c|c|c|c|}
\hline Grandes regiões & & 2010 & 2012 & 2014 & 2016 & 2018 & Têndência \\
\hline & SAI & 180 & 190 & 238 & 238 & 241 & \\
\hline \multirow[t]{3}{*}{ Centro-Oeste } & Vagas/serviços & 23,9 & 19,2 & 19,4 & 19,3 & 20,5 & \\
\hline & Acolhidos & 2.114 & 2.523 & 2.628 & 2.469 & 2.456 & \\
\hline & SAI & 266 & 271 & 342 & 391 & 402 & \\
\hline \multirow[t]{3}{*}{ Nordeste } & Vagas/serviços & 26,8 & 29,1 & 23,0 & 20,2 & 19,1 & \\
\hline & Acolhidos & 3.728 & 5.378 & 4.749 & 4.565 & 4.799 & \\
\hline & SAl & 97 & 100 & 131 & 147 & 156 & \\
\hline \multirow[t]{3}{*}{ Norte } & Vagas/serviços & 21,8 & 26,0 & 22,9 & 20,0 & 18,9 & \\
\hline & Acolhidos & 1.051 & 1.577 & 1.589 & 1.549 & 1.610 & \\
\hline & SAI & 1.419 & 1.170 & 1.359 & 1.373 & 1.366 & \\
\hline \multirow[t]{3}{*}{ Sudeste } & Vagas/serviços & 18,0 & 20,0 & 19,6 & 17,8 & 17,5 & \\
\hline & Acolhidos & 22.150 & 17.186 & 18.281 & 16.295 & 15.367 & \\
\hline & SAI & 662 & 629 & 721 & 717 & 712 & \\
\hline \multirow[t]{3}{*}{ Sul } & Vagas/serviços & 20,4 & 17,7 & 17,1 & 16,0 & 15,7 & \\
\hline & Acolhidos & 8.319 & 8.276 & 8.278 & 7.714 & 7.408 & \\
\hline & SAI & 2.624 & 2.360 & 2.791 & 2.866 & 2.877 & \\
\hline \multirow[t]{2}{*}{ Brasil } & Vagas/serviços & 20,0 & 20,6 & 19,5 & 17,9 & 17,6 & \\
\hline & Acolhidos & 37.362 & 34.940 & 35.525 & 32.592 & 31.640 & \\
\hline
\end{tabular}

Fontes: Levantamento Nacional, 2010; e Censo Suas 2012, 2014, 2016 e 2018.

O gráfico 4 revela que esse movimento do número de acolhidos, vagas e SAIs entre 2010 e 2018 tem conseguido enfrentar, em alguma medida, as desigualdades regionais. Observa-se incremento importante dessas três unidades de análise nas regióes Centro-Oeste, Nordeste e, sobretudo, Norte, as quais possuíam menor cobertura do serviço no início da série analisada. Ao mesmo tempo, é possível observar redução do número de vagas e acolhidos nas regiōes Sul e Sudeste.

GRÁFICO 4

Desempenho regional segundo quantidade de SAls, vagas e acolhidos - Brasil e Grandes Regiões (2010-2018)

(Em\%)

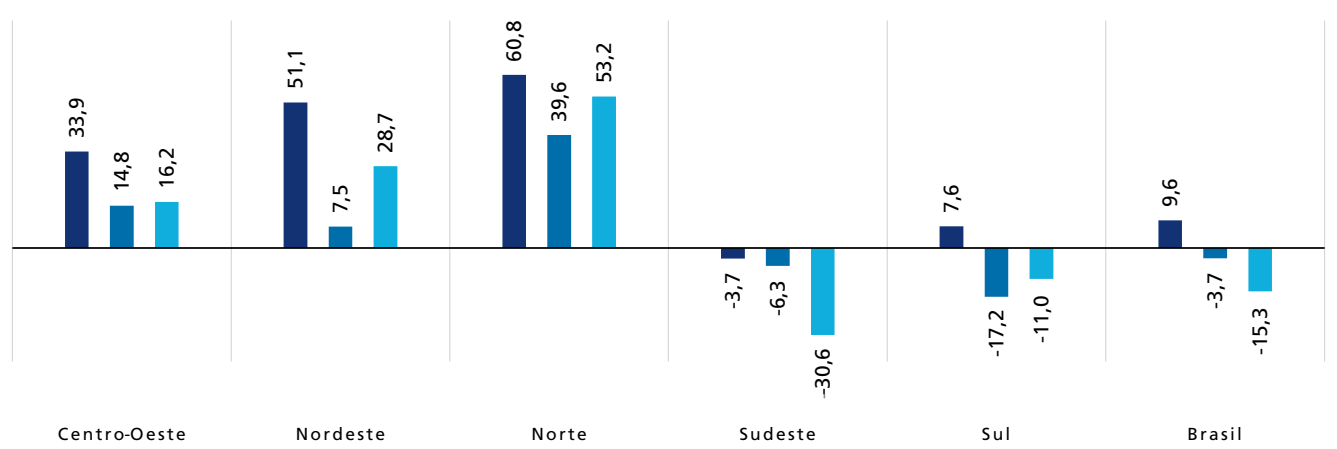

SAl Vagas Acolhidos

Fontes: Levantamento Nacional, 2010; e Censo Suas 2012, 2014, 2016 e 2018. 
Chama atenção o impacto do processo de expansão e reordenamento na regiáo Norte, na qual a ampliação foi mais expressiva nos três aspectos analisados: quantidade de SAIs $(+60,8 \%)$, vagas $(+39,6 \%)$ e acolhidos $(+53,2 \%)$. Também na regiáo Nordeste, observa-se forte expansão de SAIs $(51,1 \%)$ e do total de acolhidos (+ 28,7\%), acompanhada de ampliação mais tímida de vagas $(+7,5 \%)$. Vale registrar que esse aumento generalizado de tais serviços, em todas as regióes do país - com exceção da região Sudeste -, também pode ser resultado de avanço na institucionalidade da política, expressa não apenas por meio do aumento na oferta de serviços, como também por intermédio da capacidade de registro e coleta de informaçóes sobre SAIs existentes.

Esses dados confirmam que o esforço de cobertura e adequação da oferta no sentido do funcionamento do acolhimento institucional em pequenos grupos foi mais intenso nas regióes que estavam comparativamente piores no início da série analisada. É importante destacar que tanto a definição do parâmetro de vagas por 100 mil habitantes de 0 a 17 anos, quanto os demais critérios definidos na Resolução no 23/2013 tinham como objetivo exatamente corrigir disparidades regionais e induzir melhor distribuição da cobertura, de modo a estimular municípios com poucas ou nenhuma vaga a criarem novas, em especial aqueles de maior porte.

Todavia, ainda que esse avanço tenha sido mais significativo nas regióes originalmente com menor cobertura, os gráficos 2 a 4 revelam que ainda é pequena (menos de um terço) a participação das regiôes Norte, Nordeste e Centro-Oeste no total de SAIs, vagas e acolhidos.

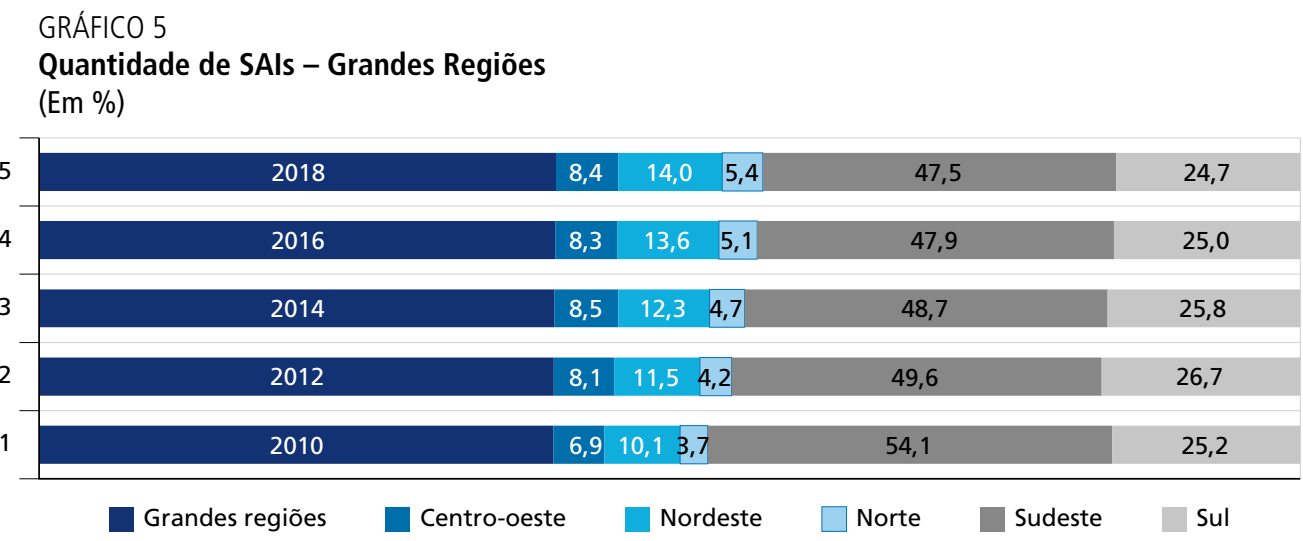

Fontes: Levantamento Nacional, 2010; e Censo Suas 2012, 2014, 2016 e 2018.

Mesmo que no período analisado se observe melhoria relativa das regióes Nordeste (de $10,1 \%$ para $14 \%$ ), Norte (de 3,7\% para 5,4\%) e Centro-Oeste (de 6,0\% para $8,4 \%$ ), a distribuição da oferta entre as regióes permanece bem heterogênea (gráfico 5). A regiáo Sudeste continua com a maior oferta de SAIs, ainda que com queda na participaçáo relativa no período analisado (de 54,1\% para 47,5\%). A regiáo Sul continua aparecendo como segunda maior provedora do serviço, com discreta diminuição na sua participação (de $25,2 \%$ para $24,7 \%)$. 


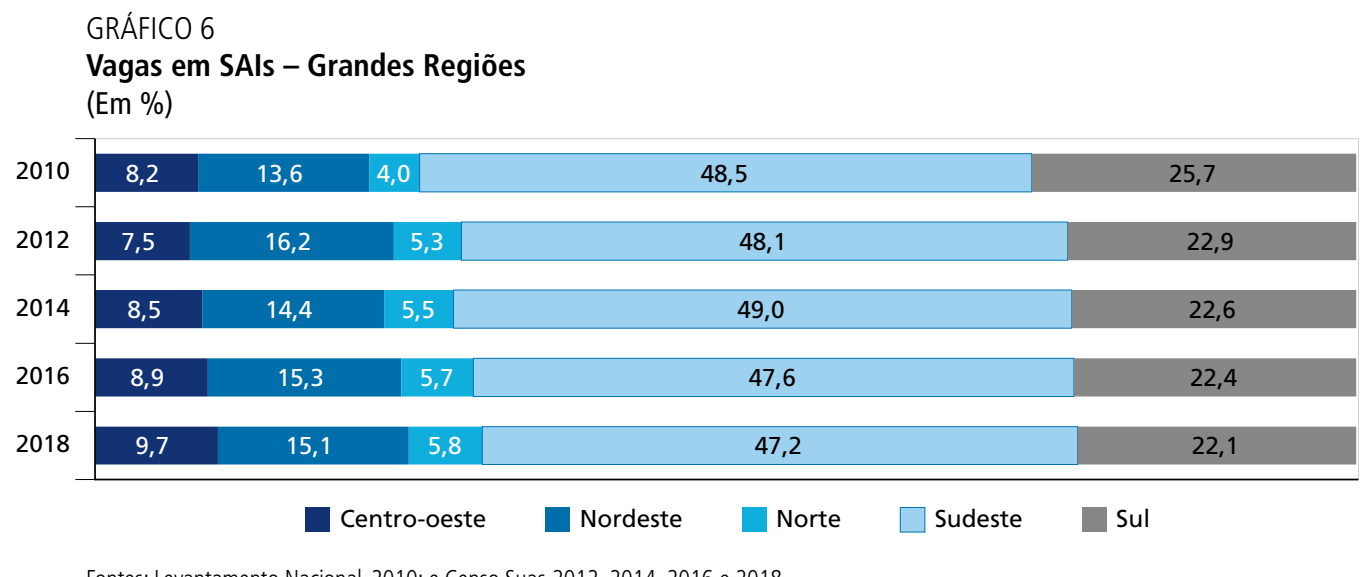

A participação regional nas vagas ofertadas pelos SAIs segue as mesmas tendências de ampliação discreta da participação das regiôes Norte, Nordeste e Centro-Oeste (gráfico 6).

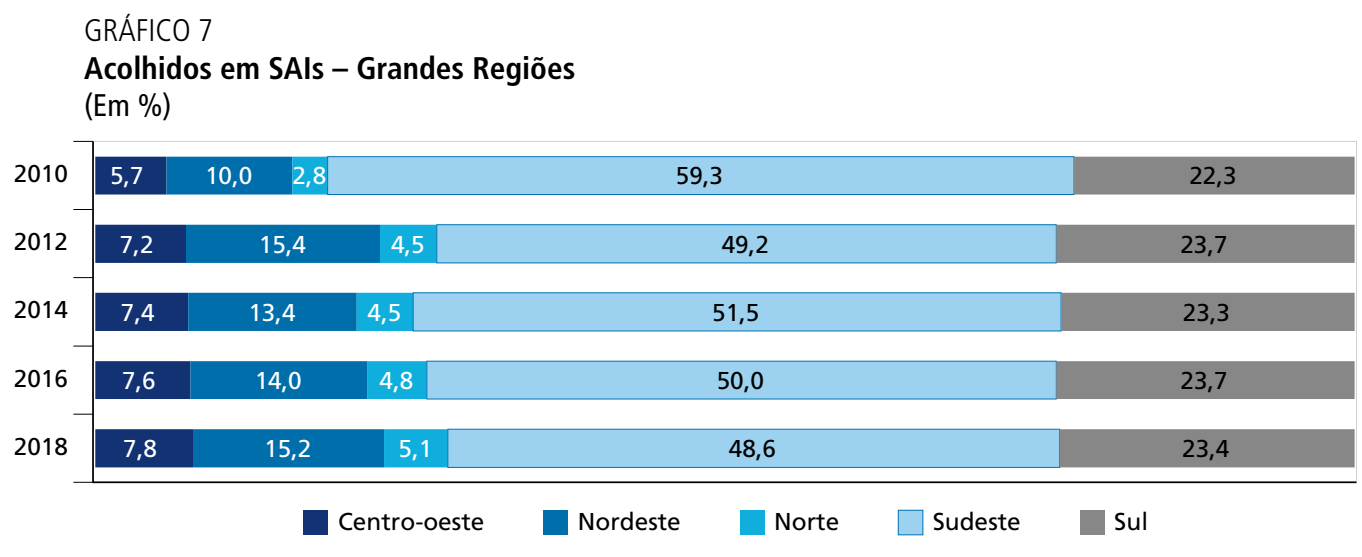

Fontes: Levantamento Nacional, 2010; e Censo Suas 2012, 2014, 2016 e 2018.

A participação regional no total de acolhidos, por sua vez, também revela ampliação das regióes Norte (de 5,7\% para 7,8\%), Nordeste (de 10\% para 15,2\%) e Centro-Oeste (de 2,8\% para 5,1\%), em detrimento das demais regióes (gráfico 7).

Observam-se, portanto, avanços importantes no processo de reordenamento da oferta preexistente. Constata-se a melhoria relativa das regióes Nordeste, Norte e Centro-Oeste em relação ao reportado em 2010, o que, contudo, ainda não foi suficiente para alterar substancialmente a participação dessas regióes no total de vagas e acolhidos. 


\subsubsection{Serviço de acolhimento familiar}

Como vimos anteriormente, a trajetória do SAF é bem mais recente - com mençóes na PNAS em 2004 e no PNCFC em 2006, regulamentação no ECA e cofinanciamento específico regulamentado em 2016. ${ }^{29}$ Remetendo às Diretrizes de Cuidados Alternativos à Criança (ONU, 2009), a Resolução CNAS no 23/2013 (art. 8o, inciso II) define especialmente essa modalidade para o caso de crianças de 0 a 3 anos de idade. $\mathrm{O}$ referido normativo estabelece ainda um limite máximo de quinze famílias acolhedoras para cada equipe técnica do serviço e com capacidade de acolhimento de uma criança ou adolescente por família ${ }^{30}$ (art. $2^{\circ}$, inciso II).

Segundo o art. 34, $\$ 1^{\circ}$ do ECA, a medida protetiva de acolhimento familiar tem preferência ao acolhimento institucional. Os dados de cobertura dos SAFs coletados pelo Censo Suas sinalizam, no entanto, dificuldades na implementação dessa diretriz, visto que, em 2018, a quantidade de acolhidos em SAFs é de apenas 4,2\% do total de acolhidos nos serviços de acolhimento, ${ }^{31}$ conforme mostrado no gráfico 8.

GRÁFICO 8

Acolhidos em SAFs sobre o total de crianças e adolescentes acolhidos - Brasil e Grandes Regiões (Em \%)

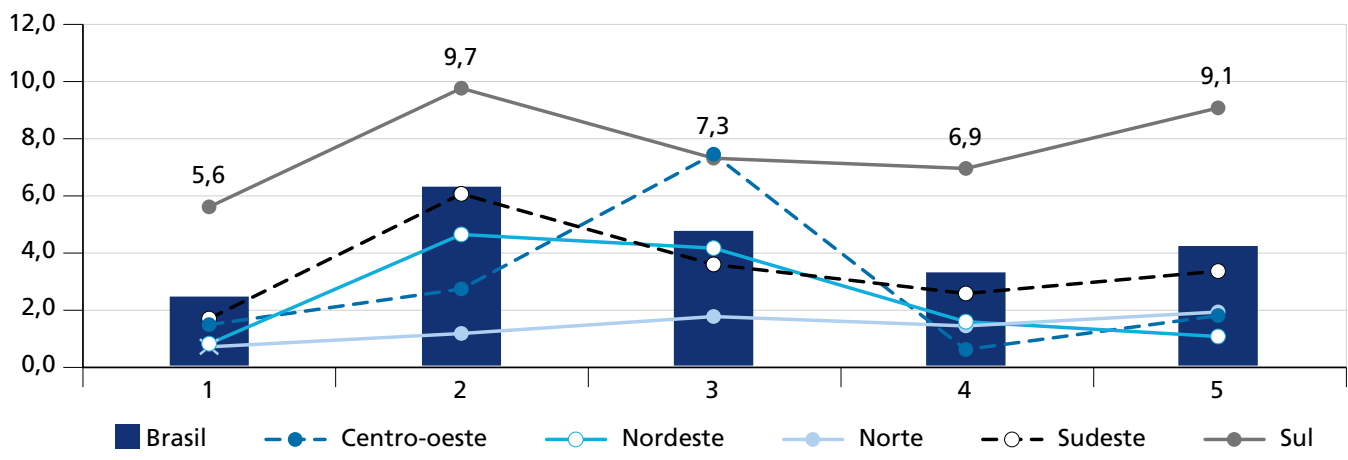

Fontes: Levantamento Nacional, 2010; e Censo Suas 2012, 2014, 2016 e 2018.

Essa implementação residual dos SAFs também é observada quando se analisam os dados por região do país. No Sul, o acolhimento familiar é um pouco mais expressivo, tendo passado de 5,6\% para 9,1\%, no período 2010-2018. Todas as regióes observaram aumento proporcional de acolhidos nesse tipo de serviço em 2012, tendo, todavia, regredido, a partir de então, a patamares próximos ou até inferiores aos de 2010 (gráfico 8).

O gráfico 9 apresenta a evolução do número de serviços, vagas ofertadas e crianças e adolescentes acolhidos em SAFs, entre 2010 e 2018.

29. 0 ECA disciplinou o cofinanciamento do acolhimento familiar a partir da Lei o 13.257/2016, que incluiu o parágrafo no art. 34 : "Poderão ser utilizados recursos federais, estaduais, distritais e municipais para a manutenção dos serviços de acolhimento em família acolhedora, facultando-se o repasse de recursos para a própria família acolhedora". A Portaria no 233/2017 do Gabinete do Ministro (GM) do MDS autorizou o uso de recursos do cofinanciamento federal do Fundo Nacional de Assistência Social (FNAS) para o repasse de recursos às famílias acolhedoras.

30. Exceto quando se tratar de grupo de irmãos, situação em que esse número poderá ser ampliado.

31. Que engloba soma de acolhidos em SAls e SAFs. 
GRÁFICO 9

Trajetória de SAFs, famílias cadastradas e número de acolhidos - Brasil'

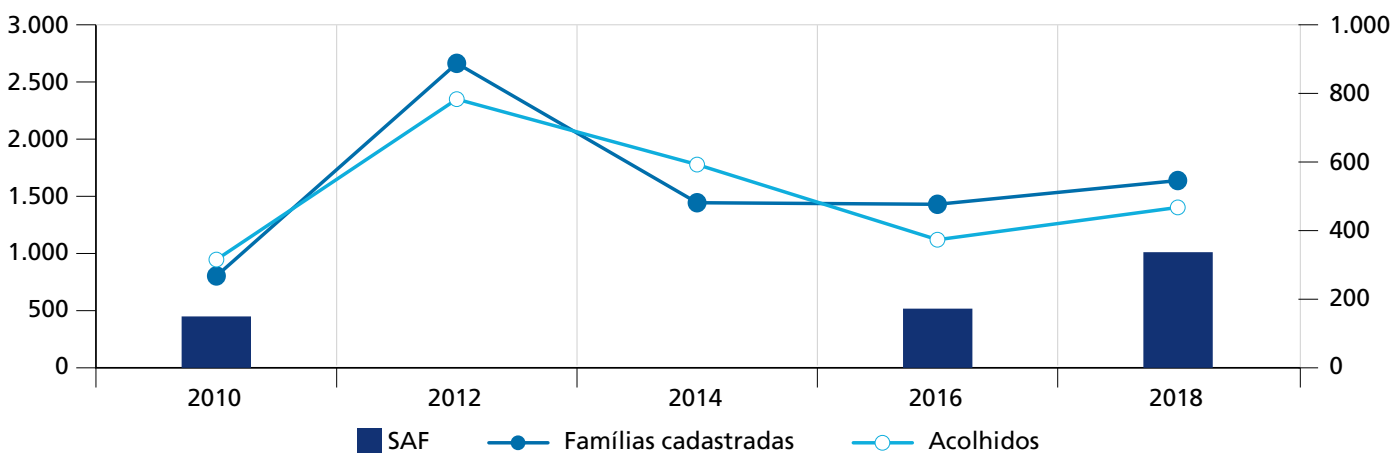

Fontes: Levantamento Nacional, 2010; e Censo Suas 2012, 2014, 2016 e 2018.

Nota: ${ }^{1} 0$ Censo Suas nos anos de 2012 e 2014 não coletou o número de SAFs existentes no país.

Entre 2010 e 2018, mais que dobrou o total de SAFs em funcionamento (+ 131,6\%), o que significou 189 serviços a mais que o início da série analisada. Observa-se também aumento no número de famílias cadastradas (+ 105,9\%, ou 838 novas famílias), todavia com ampliação menos intensa no número de crianças e adolescentes acolhidos $(+49,4 \%$, ou 460 novos acolhidos).

Interessante observar que em 2012 ocorreu o pico para duas das variáveis mensuradas: 2.664 famílias cadastradas e 2.346 acolhidos no país. No entanto, em 2014, essas variáveis apresentaram reduções importantes. As razões para isso devem ser melhor investigadas. Além das alteraçóes na forma de captar a informaçáo no questionário do Censo Suas, ${ }^{32}$ mencionadas na terceira seção, e do próprio entendimento por parte dos gestores acerca do conceito de família acolhedora, ${ }^{33}$ não se verifica nas resoluçóes do reordenamento/regionalização nenhum incentivo específico para o acolhimento familiar, o que pode ter influenciado na desmobilizaçáo em torno dos SAFs. Apenas em 2018, ensaiou-se um processo de retomada deste, provavelmente relacionado à sua regulamentação no ECA e à permissão do uso do cofinanciamento federal para custear subsídios pagos às famílias acolhedoras. ${ }^{34} \mathrm{~A}$ tabela 5 e o gráfico 10 desagregam a trajetória de SAFs, famílias cadastradas e acolhidos em nível regional.

32. Até 2014, a coleta de algumas informações sobre os SAFs era realizada por meio do questionário de gestão municipal. A partir de 2015, esse serviço foi investigado de maneira mais aprofundada nos questionários de serviços de acolhimento.

33. As técnicas da SNAS consultadas na elaboração deste relatório mencionam que no início serviços de apoio às famílias extensas, como a guarda subsidiada, acabavam sendo indevidamente inseridos como serviços de família acolhedora.

34. Tem crescido nos últimos anos o percentual de SAFs que repassam subsídios às famílias acolhedoras, passando de 72,6\%, em 2012, para 94,3\%, em 2018. A maior parte dos SAFs em $2018(56,8 \%)$ pagava entre $\mathrm{R} \$ 900,00$ e R\$ 1 mil por família. 
Reordenamento dos Serviços de Acolhimento de Crianças e Adolescentes e Implementação de Novas Modalidades - Família Acolhedora e Repúblicas

TABELA 5

Trajetória dos SAFs - Brasil e Grandes Regiões ${ }^{1}$

\begin{tabular}{|c|c|c|c|c|c|c|c|}
\hline & & \multicolumn{6}{|c|}{ Grandes Regiões } \\
\hline & & Centro-Oeste & Nordeste & Norte & Sudeste & Sul & Brasil \\
\hline \multirow{3}{*}{2010} & SAFs & 6 & 7 & 5 & 39 & 87 & 144 \\
\hline & Famílias cadastradas & 22 & 30 & 10 & 292 & 437 & 791 \\
\hline & Acolhidos & 31 & 29 & 7 & 373 & 492 & 932 \\
\hline \multirow{2}{*}{2012} & Famílias cadastradas & 77 & 774 & 41 & 1.015 & 757 & 2.664 \\
\hline & Acolhidos & 70 & 260 & 18 & 1.104 & 894 & 2.346 \\
\hline \multirow{2}{*}{2014} & Famílias cadastradas & 62 & 179 & 73 & 644 & 475 & 1.433 \\
\hline & Acolhidos & 211 & 205 & 28 & 675 & 651 & 1.770 \\
\hline \multirow{3}{*}{2016} & SAFs & 4 & 17 & 8 & 71 & 67 & 167 \\
\hline & Famílias cadastradas & 8 & 127 & 41 & 710 & 536 & 1.422 \\
\hline & Acolhidos & 14 & 72 & 22 & 424 & 575 & 1.107 \\
\hline \multirow{3}{*}{2018} & SAFs & 20 & 28 & 15 & 119 & 151 & 333 \\
\hline & Famílias cadastradas & 44 & 74 & 71 & 685 & 755 & 1.629 \\
\hline & Acolhidos & 44 & 50 & 31 & 529 & 738 & 1.392 \\
\hline
\end{tabular}

Fontes: Levantamento Nacional, 2010; e Censo Suas 2012, 2014, 2016 e 2018.

Nota: ${ }^{1} 0$ Censo Suas de 2012 e 2014 não coletou o número de SAFs existentes no país.

GRÁFICO 10

Quantidade de SAFs - Grandes Regiões (2010, 2016 e 2018)

(Em \%)

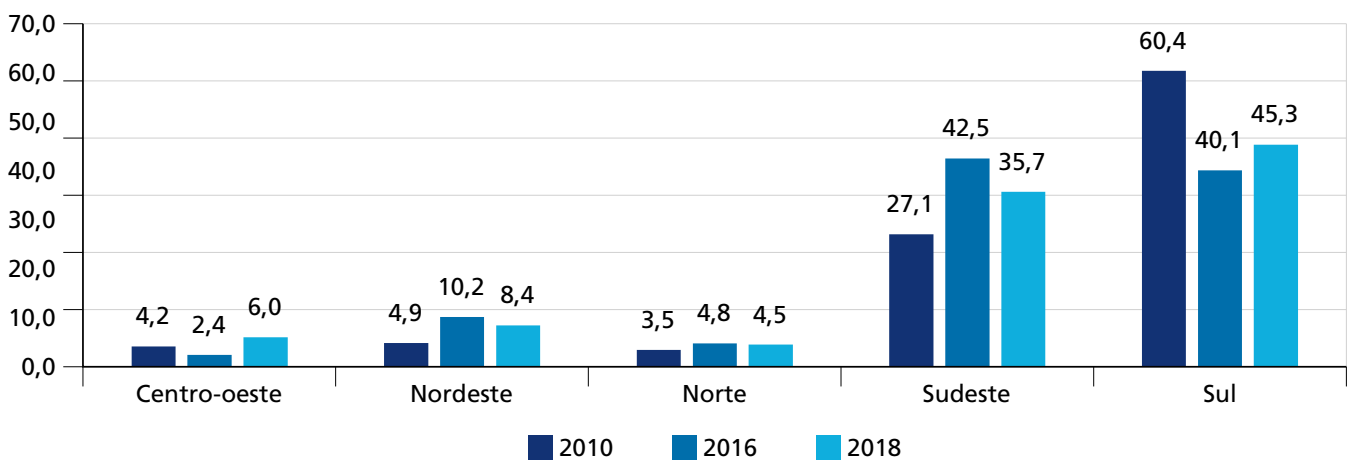

Fonte: Levantamento Nacional, 2010; e Censo Suas 2016 e 2018.

TABELA 6

Famílias cadastradas em SAFs - Grandes Regiões

(Em \%)

\begin{tabular}{lccccc}
\hline Grandes Regiões & 2010 & 2012 & 2014 & 2016 & 2018 \\
\hline Centro-Oeste & 2,8 & 2,9 & 4,3 & 0,6 & 2,7 \\
Nordeste & 3,8 & 29,1 & 12,5 & 8,9 & 4,5 \\
Norte & 1,3 & 1,5 & 5,1 & 2,9 & 4,4 \\
Sudeste & 36,9 & 48,1 & 34,9 & 49,9 & 42,1 \\
Sul & 55,2 & 28,4 & 33,1 & 37,7 & 46,3 \\
\hline
\end{tabular}

Fontes: Levantamento Nacional, 2010; e Censo Suas 2012, 2014, 2016 e 2018. 
TABELA 7

Acolhidos em SAFs - Brasil e Grandes Regiões

(Em \%)

\begin{tabular}{lrrrrr}
\hline Grandes Regiões & 2010 & 2012 & 2014 & 2016 & 2018 \\
\hline Centro-Oeste & 3,3 & 3,0 & 11,9 & 1,3 & 3,2 \\
Nordeste & 3,1 & 11,1 & 11,6 & 6,5 & 3,6 \\
Norte & 0,8 & 0,8 & 1,6 & 2,0 & 2,2 \\
Sudeste & 40,0 & 47,1 & 38,1 & 38,3 & 38,0 \\
Sul & 52,8 & 38,1 & 36,8 & 51,9 & 53,0 \\
Brasil & 100 & $\mathbf{1 0 0}$ & $\mathbf{1 0 0}$ & $\mathbf{1 0 0}$ & $\mathbf{1 0 0}$ \\
\hline
\end{tabular}

Fontes: Levantamento Nacional, 2010; e Censo Suas 2012, 2014, 2016 e 2018.

A distribuição regional da oferta do acolhimento familiar também segue bastante desigual, indicando - para além do incentivo à expansão do SAF como um todo - a necessidade de algo mais direcionado às regióes Norte, Nordeste e Centro-Oeste. Há uma série de desafios para a expansão da modalidade de acolhimento familiar no Brasil. ${ }^{35}$ Uma destas é a cultura de institucionalização que, segundo o próprio PNCFC, deve ser superada. Por motivos a serem investigados, algumas regióes parecem ser mais abertas a essa modalidade do que outras.

\subsection{Cobertura de serviços de acolhimento por municípios}

De acordo com o PNCFC, os serviços de acolhimento devem localizar-se em áreas residenciais, o mais próximo possível dos locais de origem de crianças e adolescentes acolhidos. Essa também é uma das diretrizes previstas nas Orientaçóes Técnicas (Brasil, 2009). Para tanto, é necessário que esses serviços estejam disponíveis em todo o território nacional. É nessa perspectiva que observamos, nesta subseção, como os municípios têm se organizado para prover essa oferta.

A expansão e o reordenamento da oferta de vagas nos serviços de acolhimento (institucional ou familiar) contam com estímulo financeiro federal equivalente a $\mathrm{R} \$ 5$ mil mensais para cada dez vagas (Resoluçáo CNAS nº 23/2013) - média de $\mathrm{R} \$$ 500,00 mensais por vaga -, o que representa entre $15 \%$ e $25 \%$ do custo total da oferta estimado. ${ }^{36} \mathrm{O}$ valor restante costuma ser financiado pelo ente municipal e/ou estadual, mediante recursos próprios, ou oriundos de doaçôes e outras fontes não governamentais. Ainda que o incentivo federal seja relevante, este é insuficiente para garantir a oferta local, sobretudo onde o custo de vida é mais alto.

\footnotetext{
35. Estudo sobre a implementação do acolhimento familiar do município de São Luiz, no Maranhão, traz alguns desses desafios: a ausência de divulgação e priorização financeira, por parte do órgão gestor; as fragilidades de compreensão do serviço, por vários sujeitos do Sistema de Garantia de Direitos da Criança e do Adolescente; a rotatividade dos sujeitos que possuem o poder de decisão da medida protetiva; e a ausência de articulação entre as instituições do SGDCA e do Família Acolhedora (Nunes, 2020).

36. A Universidade Federal de Minas Gerais (UFMG, 2018) desenvolveu, a pedido do MC, um modelo para identificar o custeio global da prestação de serviços socioassistenciais no Suas, de acordo com o porte, o perfil assistencial e demais atributos destes, além da proposição de formas de apuração e da estrutura de gastos. De acordo com esse modelo, o custo médio mensal da oferta dos SAls para crianças e adolescentes, a qual propõe o custo médio mensal de funcionamento de um abrigo, com capacidade de até vinte vagas, é de $R \$ 49.511,01$, o que equivale a $R \$ 2.475,55$ por vaga. No caso das casas-lares, com capacidade de até dez vagas, o custo mensal é de $R \$ 35.946,73$, ou $R \$ 3.594,68$ por vaga (op. cit.). Por sua vez, no caso do acolhimento familiar, que possui capacidade de mobilizar até quinze famílias acolhedoras, o custo mensal estimado - afora o eventual subsídio pago à família que acolhe - é de R\$1.980,60. Esses valores foram apurados em pesquisa conduzida por pesquisadores da UFMG, vinculados ao Observatório de Custos (Núcleo Observatório de Custos e Economia da Saúde - Noces).
} 
É à luz desses incentivos que chamamos atenção para o aumento gradual, porém expressivo, no total de municípios com oferta de SAIs para crianças e adolescentes. A tabela 8 mostra que, em 2010, essa oferta estava presente em 1.157 municípios, chegando a 1.710 em 2018, (+ 47,8\% ou 553 municípios). As regióes que mais expandiram nesse aspecto foram o Nordeste $(129,4 \%)$ e o Norte $(95,1 \%)$, seguidas do Centro-Oeste $(61,5 \%)$.

TABELA 8

Municípios com ao menos um SAI - Brasil e Grandes Regiões

\begin{tabular}{|c|c|c|c|c|c|c|}
\hline Grandes Regiões & 2010 & 2012 & 2014 & 2016 & 2018 & $\begin{array}{c}\text { Variação -2010-2018 } \\
(\%)\end{array}$ \\
\hline Centro-Oeste & 109 & 122 & 157 & 166 & 176 & 61,5 \\
\hline Nordeste & 109 & 128 & 185 & 229 & 250 & 129,4 \\
\hline Norte & 61 & 68 & 95 & 111 & 119 & 95,1 \\
\hline Sudeste & 550 & 561 & 670 & 709 & 735 & 33,6 \\
\hline Sul & 328 & 352 & 398 & 415 & 430 & 31,1 \\
\hline Brasil & 1.157 & 1.231 & 1.505 & 1.630 & 1.710 & 47,8 \\
\hline
\end{tabular}

Fontes: Levantamento Nacional, 2010; e Censo Suas 2012, 2014, 2016 e 2018.

No caso do acolhimento familiar, apresentado na tabela 9, verificamos, entre 2010 e 2018, um incremento de 184 municípios com pelo menos um serviço (139,5\%). A análise ano a ano sugere que, em 2012, ocorreu o pico na quantidade de municípios com SAFs em todas as regiôes. A região Sul é a que mais aumentou a quantidade de municípios com esse tipo de serviço, ainda que tenha ficado em desvantagem em termos proporcionais, devido ao fato de que, nas demais regióes - que apresentavam poucos municípios com pelo menos um SAF em 2010 -, qualquer ampliaçáo se mostra percentualmente mais significativa.

TABELA 9

Municípios com ao menos um SAF - Brasil e Grandes Regiões

\begin{tabular}{|c|c|c|c|c|c|c|}
\hline Grandes Regiões & 2010 & 2012 & 2014 & 2016 & 2018 & $\begin{array}{c}\text { Variação } \\
(\%)\end{array}$ \\
\hline Centro-Oeste & 6 & 23 & 16 & 4 & 20 & 233,3 \\
\hline Nordeste & 7 & 30 & 24 & 16 & 27 & 285,7 \\
\hline Norte & 5 & 21 & 22 & 8 & 15 & 200,0 \\
\hline Sudeste & 27 & 135 & 132 & 56 & 104 & 285,2 \\
\hline Sul & 87 & 159 & 121 & 67 & 150 & 72,4 \\
\hline Brasil & 132 & 368 & 315 & 151 & 316 & 139,4 \\
\hline
\end{tabular}

Fontes: Levantamento Nacional, 2010; e Censo Suas 2012, 2014, 2016 e 2018.

A pesquisa do Ipea e do Conanda mostrou que, à época, a oferta dos serviços de acolhimento era predominantemente localizada nos grandes centros urbanos (Silva, 2004). A pesquisa da Fiocruz e do MDS (Assis e Faria, 2013), por sua vez, identificou vazios de oferta que influenciaram a definição dos critérios de reordenamento e regionalização implementados a partir de 2013. Os critérios de elegibilidade para receber o cofinanciamento federal (Resolução CNAS no 23/2013, art. 23) beneficiam municípios com mais de 50 mil habitantes (médio/grande porte e metrópoles) ${ }^{37}$ que sejam sede de comarca judicial, o que 
favorece a interiorização e a integração do serviço com o SGDCA. Municípios de pequeno porte I e II também podem receber cofinanciamento, caso possuam aceite para implantação de centros de referência de assistência social (Cras) e de centros de referência especializados de assistência social (Creas). Ou seja, municípios maiores e os menores com algum grau de institucionalizaçáo do Suas constituem público elegível para receber o cofinanciamento previsto no reordenamento.

Analisando a distribuição desses serviços por municípios segundo o porte populacional, verificamos, na tabela 10 , um movimento de "interiorização" da oferta dos SAIs, de modo a favorecer a preservação e o fortalecimento de vínculos do acolhido com os familiares e a comunidade de origem.

TABELA 10

Número de SAls, por porte dos municípios

\begin{tabular}{lcccccc}
\hline Porte & 2010 & 2012 & 2014 & 2016 & 2018 & $\begin{array}{c}\text { Variação - 2010-2018 } \\
(\%)\end{array}$ \\
\hline Metrópole & 626 & 463 & 503 & 493 & 479 & $-23,5$ \\
Grande & 879 & 764 & 872 & 857 & 828 & $-5,8$ \\
Médio & 306 & 286 & 352 & 375 & 367 & 19,9 \\
Pequeno II & 457 & 454 & 556 & 587 & 594 & 30,0 \\
Pequeno I & 349 & 393 & 508 & 554 & 609 & 74,5 \\
Sem informação & 7 & - & - & - & - & - \\
Total & $\mathbf{2 . 6 2 4}$ & $\mathbf{2 . 3 6 0}$ & $\mathbf{2 . 7 9 1}$ & $\mathbf{2 . 8 6 6}$ & $\mathbf{2 . 8 7 7}$ & $\mathbf{9 , 6}$ \\
\hline
\end{tabular}

Fontes: Levantamento Nacional, 2010; e Censo Suas 2012, 2014, 2016 e 2018.

Municípios menores, de pequeno porte II (de 20 a 50 mil habitantes) e, principalmente, de pequeno porte I (até 20 mil habitantes) foram os mais beneficiados pela criação de novos SAIs, ampliando 30\% e 74,5\%, respectivamente, sua oferta em relação a 2010 . Por sua vez, verifica-se redução no número de serviços em municípios de grande porte $(-5,8 \%)$ e metrópoles $(-23,5 \%) .^{38}$

A tabela 11, por sua vez, revela que todas as metrópoles e a quase totalidade dos municípios de grande porte ${ }^{39}$ contavam com pelo menos um SAI em 2018. A cobertura nos municípios de médio porte também era expressiva $(87,4 \%)$. Por seu turno, pouco mais da metade dos municípios de pequeno porte II e apenas 15,4\% daqueles de pequeno porte I possuíam pelo menos um SAI.

38. Uma realidade que o reordenamento parece ter impactado são os serviços de acolhimento concentrados na capital, inclusive para atendimento de crianças e adolescentes do interior do estado.

39. Exceção é o município de Maranguape-CE. 
TABELA 11

Municípios com pelo menos um SAl, por porte (2018)

\begin{tabular}{lccc}
\hline Porte & Total de municípios & Número de municípios com pelo menos um SAl & $\begin{array}{c}\text { Municípios com pelo menos um SAl } \\
(\%)\end{array}$ \\
\hline Metrópole & 17 & 17 & 100,0 \\
Grande & 266 & 265 & 99,6 \\
Médio & 325 & 284 & 87,4 \\
Pequeno II & 1.043 & 542 & 52,0 \\
Pequeno I & 3.919 & 602 & 15,4 \\
\hline
\end{tabular}

Fonte: Censo Suas 2018.

Esse resultado sugere que, embora os menores municípios tenham sido os que mais se beneficiaram da criação de novos SAIs no período analisado, o deficit ainda é significativo, razáo pela qual se faz necessário repensar as novas estratégias que ampliem a cobertura da oferta desses serviços para esses municípios.

TABELA 12

Municípios com pelo menos um SAF, por porte (2018)

\begin{tabular}{lccc}
\hline Porte populacional & Total de municípios & Número de municípios com pelo menos um SAF & $\begin{array}{c}\text { Municípios com pelos menos um SAF } \\
(\%)\end{array}$ \\
\hline Metrópole & 17 & 6 & 35,3 \\
Grande & 266 & 62 & 23,3 \\
Médio & 325 & 28 & 8,6 \\
Pequeno II & 1.043 & 51 & 4,9 \\
Pequeno I & 3.919 & 169 & 4,3 \\
\hline
\end{tabular}

Fonte: Censo Suas 2018.

$\mathrm{Na}$ análise por porte dos municípios com pelo menos um SAF, verifica-se que a respectiva cobertura ainda é muito baixa, alcançando 35,3\% das metrópoles e menos de 5\% dos municípios de pequeno porte I e II.

\subsubsection{Oferta regionalizada de SAls}

$\mathrm{Na}$ análise sobre a cobertura dos serviços no nível municipal, é importante considerar que aqueles de pequeno porte I, com até 20 mil habitantes, constituem mais de $70 \%$ dos municípios do país. Todavia, esses respondem por cerca de $15 \%$ da populaçáo e, portanto, sua demanda individual pode não justificar a instalação de pelo menos um serviço por município, nos moldes definidos no processo de reordenamento. Para esses casos, a estratégia mais indicada consiste na estruturação de oferta regionalizada, mediante a qual um mesmo serviço pode atender a um grupo de municípios contíguos ou de uma mesma região a partir de medidas como o compartilhamento de equipes técnicas, por exemplo.

Nesses termos, a cobertura de vagas a serem definidas no plano de acolhimento do município deve considerar a demanda e a oportunidade de estabelecer um dos modelos de regionalização da oferta previstos na Resolução CNAS no 31/2013, com apoio do respectivo governo estadual e com vistas a garantir a universalizaçáo do acesso e a integralidade da proteção socioassistencial dos cidadãos. ${ }^{40}$ 
São dois os modelos de regionalização da oferta do SAI de crianças e adolescentes nos termos da Resolução CNAS no 31/2013. O primeiro serviço é prestado sob gestão estadual. No segundo modelo, o serviço opera na modalidade de consórcio, sob gestão de município-polo, que oferece o serviço a um conjunto de municípios próximos. Em ambos os casos, a norma prevê tanto o cofinanciamento federal como o cofinanciamento estadual, este último na proporção mínima de $50 \%$ do valor do cofinanciamento federal (art. 28, $\$ 3^{\circ}$ ). A área de abrangência da oferta regionalizada dos serviços pode ser composta por dois ou mais municípios, podendo chegar a oito, no caso em que a soma da população destes não ultrapasse 160 mil habitantes e a distância para a unidade regional não ultrapasse duas horas de deslocamento (art. 17).

Essa resolução determina que estados que mantêm oferta de serviços de acolhimento em municípios de grande porte ou metrópole deverão gradualmente transferir sua execução para o respectivo município (art. 22). Sob a ótica da regionalização, a unidade estadual de acolhimento deve priorizar o atendimento da demanda pelo serviço por parte dos entes que não conseguiram estruturar oferta própria e, assim, proporcionar a oferta em locais mais próximos às residências das famílias dos acolhidos.

GRÁFICO 11

Número de SAI governamentais, ${ }^{1}$ vagas e acolhidos sob gestão estadual (2010 e 2012)

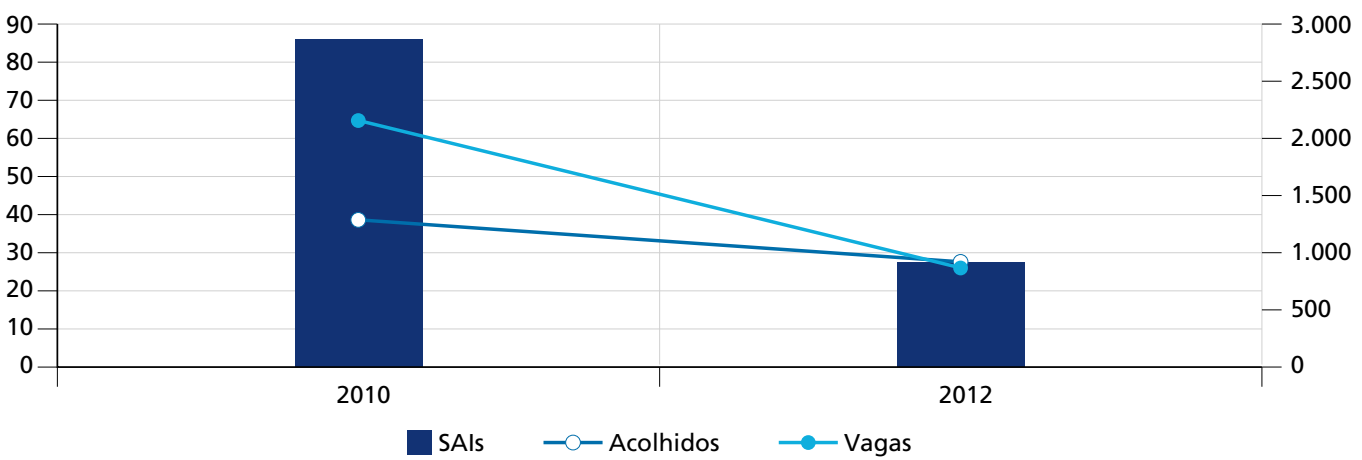

Fontes: Levantamento Nacional 2010; e Censo Suas 2012.

Nota: Entre 2010 e 2012 foram coletados dados apenas de SAl estaduais governamentais. Até 2013, as unidades estaduais ainda não eram obrigatoriamente regionalizadas.

O gráfico 11 aborda a oferta do serviço sob gestão governamental estadual, ${ }^{41}$ ilustrando redução significativa no número de SAIs no período 2010-2012 - que, de 86, passou a contar com apenas 27 serviços. Essa retração também se reflete na redução do número de acolhidos (de 1.275 para 905) e, principalmente, de vagas (de 2.150 para 851 ) nesse período.

O advento da estratégia de regionalização iniciado pela Res. CNAS no 31/2013 - que restringiu a oferta de SAIs estaduais apenas para atendimento regionalizado - náo conseguiu recompor a oferta estadual, de modo que identificamos apenas 22 SAIs governamentais geridos por este nível de governo em 2018.

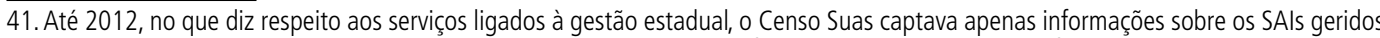
diretamente pelo estado, ou seja, governamentais. Não havia coleta de informações sobre os serviços ofertados por OSCs apoiadas pela gestão estadual, razão pela qual tivemos que separar a análise da série histórica em duas fases (2010-2012 e 2014-2018). 
GRÁFICO 12

Número de SAls ligados à gestão estadual, ${ }^{1}$ vagas e acolhidos (2014, 2016 e 2018)

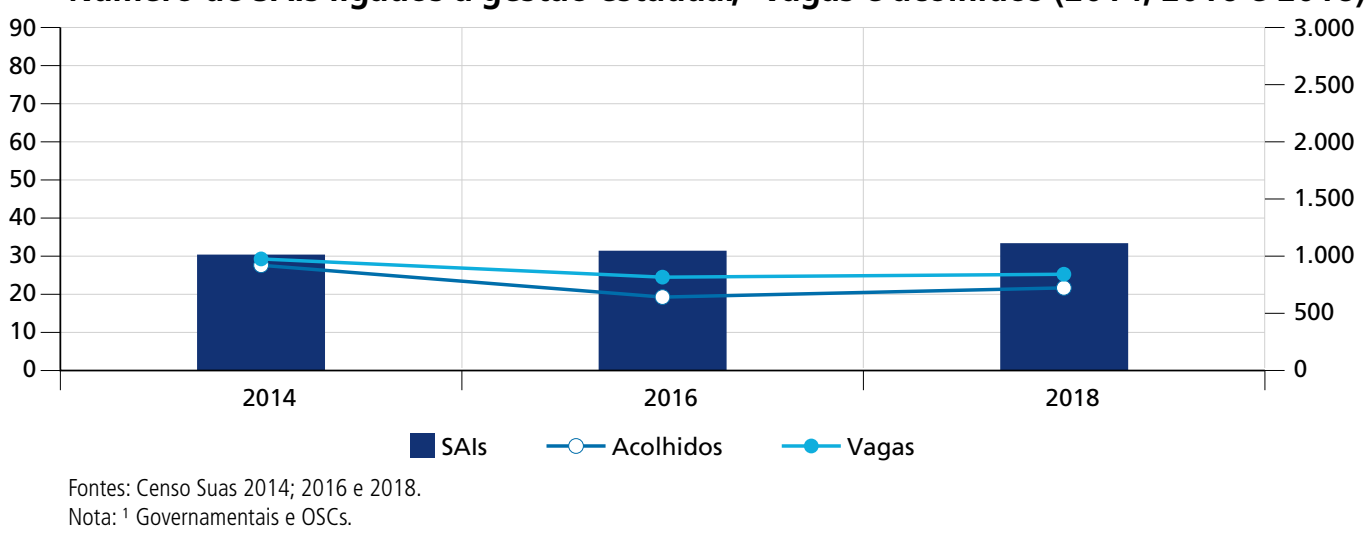

A partir de 2014, o Censo Suas permitiu captar também os SAIs geridos por OSCs que recebem financiamento estadual para execução das suas atividades. Nesse caso, somando tais serviços com aqueles governamentais estaduais, identificamos, em 2018, 33 SAIs que ofertavam 826 vagas e possuíam 707 acolhidos (gráfico 12) - números que continuam bem aquém da atuação estadual captada em 2010.

A expressiva redução de unidades de acolhimento ligados à gestáo estadual evidencia que diversos entes deixaram de operar serviços de acolhimento de crianças e adolescentes no período analisado. Se em 2010, vinte estados operavam serviços próprios, ${ }^{42} \mathrm{em} 2018$ apenas nove ${ }^{43}$ possuíam esse tipo de serviço, seja operando-os diretamente, seja mediante operaçáo por parte de OSCs.

Como vimos anteriormente, a oferta regionalizada é essencial para garantir a cobertura da esmagadora maioria dos municípios menores, especialmente pequeno porte I (até $20 \mathrm{mil}$ habitantes), os quais apresentam maior dificuldade em estruturar oferta própria. A regiáo Sul, por exemplo, deixou de operar serviços estaduais a partir de 2012. ${ }^{44}$ Diversos estados das regiôes Sudeste (São Paulo, Minas Gerais e Espírito Santo), Centro-Oeste (Goiás e Mato Grosso), Norte (Amazonas, Roraima e Pará) e Nordeste (Bahia, Maranhão e Rio Grande do Norte) deixaram de manter unidades próprias. Tocantins, Acre e Alagoas não chegaram a operar serviços dessa natureza em nenhum dos anos considerados. Ademais, é possível identificar na regiáo Nordeste alguns casos em que o modelo de regionalizaçáo por meio de unidade estadual constitui opção mais consolidada, funcionando em todo o período analisado (Ceará, Pernambuco, Sergipe, Amapá e Roraima).

Em 2018, havia 212 municípios - todos de pequeno porte I e II - que declaravam estar vinculados a pelo menos um SAI com oferta regionalizada. Desse conjunto, 132 municípios não possuíam oferta própria de serviço, contando apenas com a oferta regionalizada. Coincidindo com os achados sinalizados no mapa anterior, constata-se que a regiáo Nordeste é a que possui mais municípios nessa situação (116).

42. Amapá, Bahia, Ceará, Espírito Santo, Goiás, Maranhão, Mato Grosso do Sul, Pará, Paraíba, Pernambuco, Piauí, Paraná, Rio de Janeiro, Rio Grande do Norte, Rondônia, Roraima, Rio Grande do Sul, Santa Catarina, Sergipe e São Paulo.

43. Amapá, Ceará, Pará, Paraíba, Pernambuco, Piauí, Rio de Janeiro, Roraima e Sergipe.

44. Rio Grande do Sul fechou os 21 serviços que operavam em 2010. 
FIGURA 1

Perfil da oferta dos serviços de acolhimento, por município (2018)

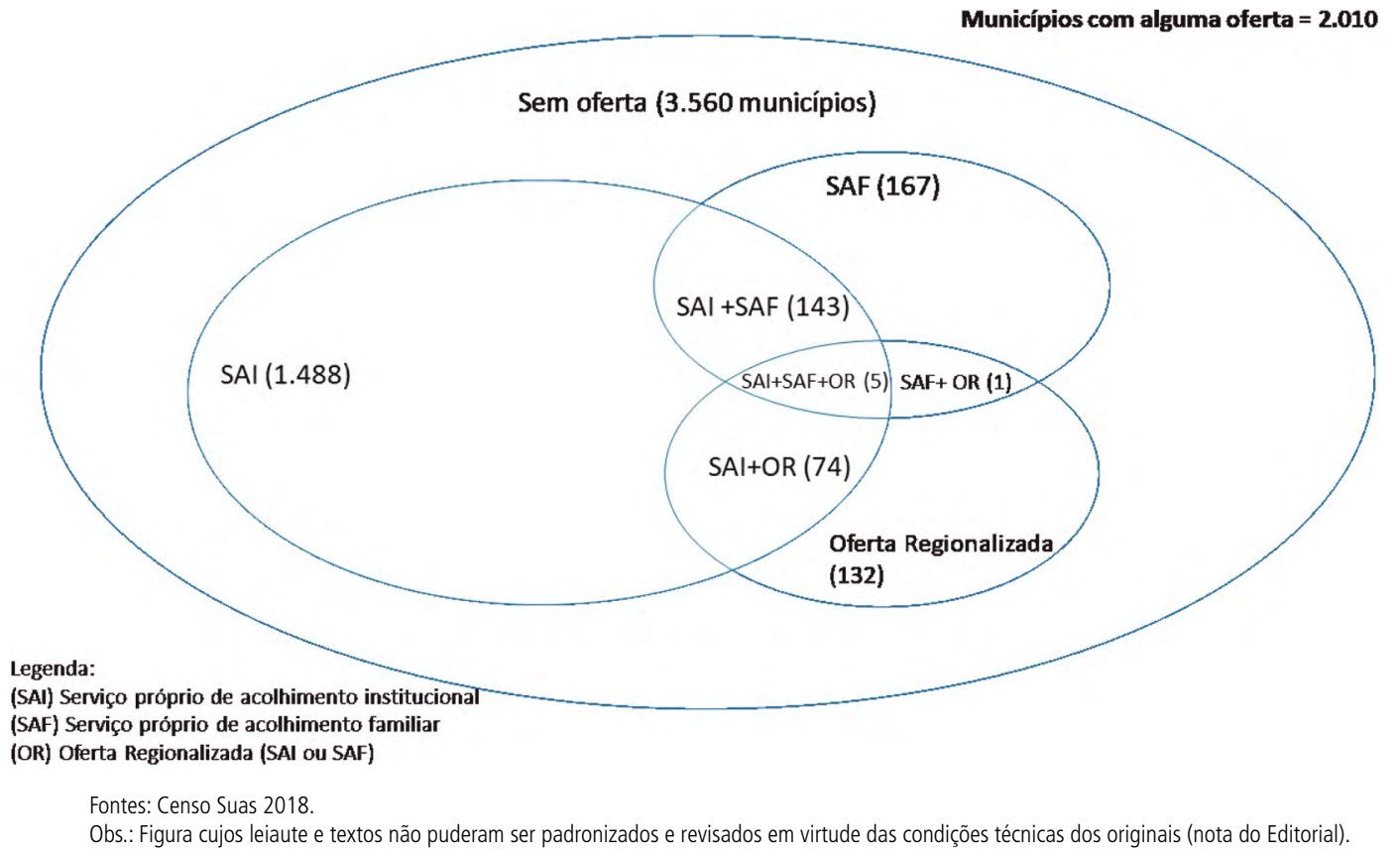

Em 2018, 2.010 municípios (36,1\%) contavam com alguma oferta do serviço de acolhimento para crianças e adolescentes, os quais cobriam, no entanto, $80,3 \%$ da população brasileira, segundo as estimativas populacionais do IBGE para 2018. Desses municípios, 1.488 apresentavam apenas oferta própria de SAIs e 167 ofertavam exclusivamente os SAFs. Cento e trinta e dois municípios não possuíam oferta própria, mas estavam vinculados a alguma oferta regionalizada (SAIs ou SAFs). Embora menos frequente, foi possível encontrar municípios com perfis mistos de ofertas: cinco municípios ofertavam tanto SAIs quanto SAFs, além de estarem vinculados a alguma oferta regionalizada; 143 municípios ofereciam SAIs e SAFs; quatro disponibilizavam SAIs e estavam vinculados a alguma oferta regionalizada; e apenas um município possuía, ao mesmo tempo, oferta própria de SAFs e vínculo com alguma oferta regionalizada. ${ }^{45} \mathrm{O}$ mapa 2 mostra como esses sete perfis de municípios se distribuíam no país em 2018. 
MAPA 2

Distribuição dos municípios, segundo perfil da oferta dos serviços de acolhimento para crianças e adolescentes (2018)
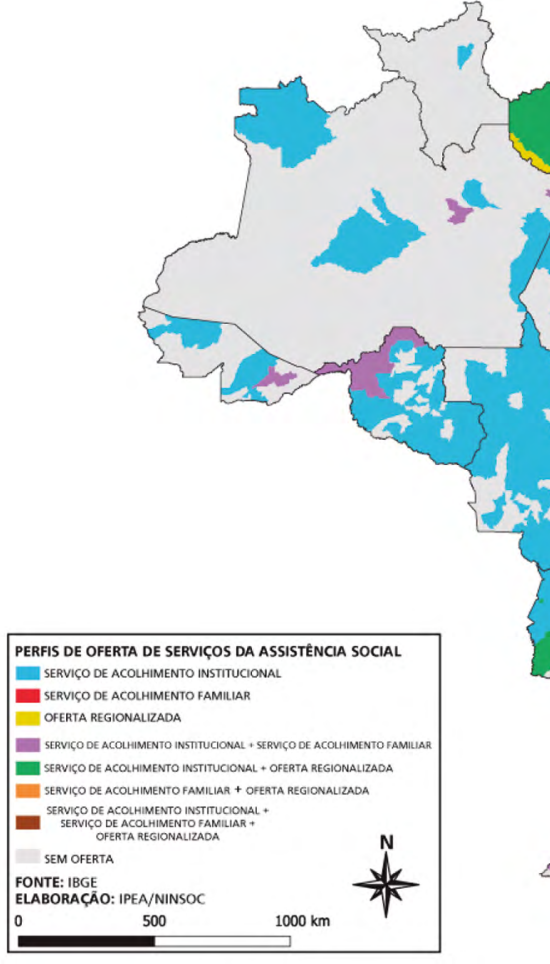

Fonte: Censo Suas 2018

Ainda que a cobertura em termos de vagas revele que os serviços de acolhimento de crianças e adolescentes cubram boa parte do seu público-alvo segundo o parâmetro de cinquenta vagas a cada 100 mil habitantes de 0 a 17 anos, a oferta do serviço continua como exceção nos municípios menores. A maior parte dos 3.560 municípios sem oferta alguma do serviço são de pequeno porte I (86\%) e II $(12,8 \%),{ }^{46}$ com vazios de oferta encontrados sobretudo nas regióes Norte e Nordeste, ainda que essas regióes estejam entre as que mais criaram serviços e vagas entre 2010 e 2018 . Portanto, na perspectiva proposta pelo Suas de garantia da integralidade do acesso aos direitos socioassistenciais, resta como desafio a implementaçáo de medidas mais efetivas para criaçáo de ofertas de acolhimento de crianças e adolescentes nos municípios menores.

\subsection{Modalidades dos SAIs}

De acordo com as Orientaçóes Técnicas (Brasil, 2009) são duas as modalidades de acolhimento institucional destinadas a crianças e adolescentes de 0 a 17 anos. A modalidade 
abrigo institucional - que funciona mediante escala de funcionários ${ }^{47}$ e acolhe no máximo vinte crianças e adolescentes - e a modalidade casa-lar - a qual comporta no máximo dez acolhidos e funciona mediante $\mathrm{o}$ apoio de um educador/cuidador que reside na unidade. ${ }^{48}$

O que diferencia ambas as modalidades não é necessariamente o número de vagas ou de acolhidos. Embora o abrigo institucional também tenha características que favoreçam a construção de vínculos entre crianças e adolescentes e seus cuidadores (como o funcionamento mediante escala de funcionários em turnos fixos, de modo que sempre o mesmo educador desenvolva determinadas tarefas da rotina diária - café da manhã, almoço, jantar, banho etc.), a estrutura da casa-lar aproxima-se mais à de uma unidade familiar já que deve funcionar em edificação residencial e contar com a presença de uma "mãe social", 49 função exercida por educador/cuidador residente (pessoa ou casal que mora na unidade com as crianças/ adolescentes atendidos) responsável pelos cuidados e pela organização da rotina da casa.

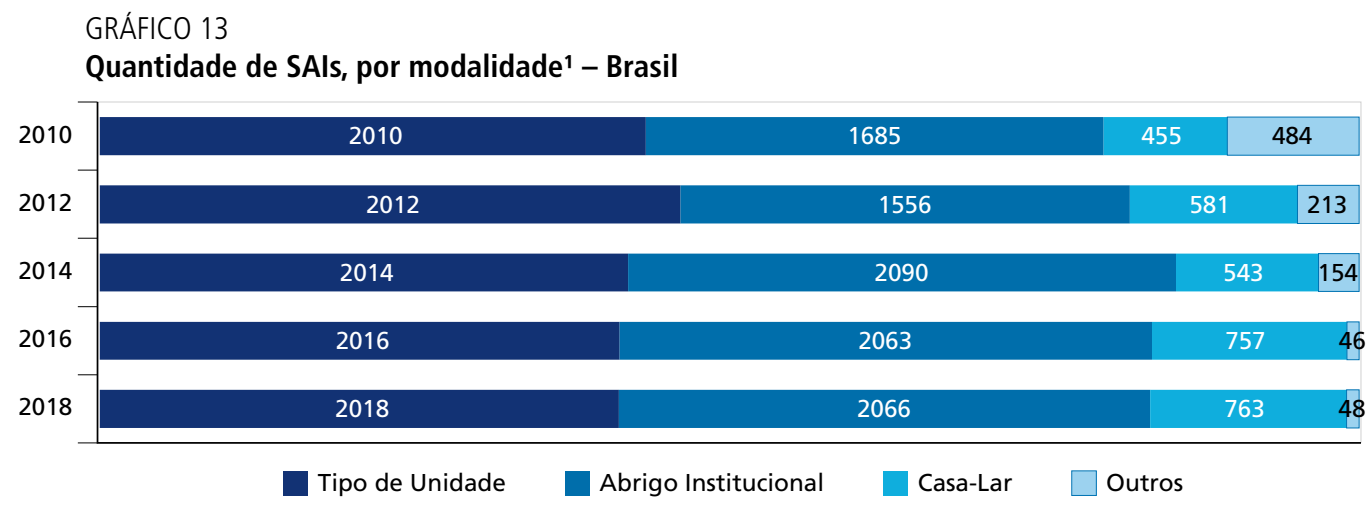

Fontes: Levantamento Nacional, 2010; e Censo Suas 2012, 2014, 2016 e 2018.

Nota: ${ }^{1}$ Inclui outras modalidades de atendimento que deixaram de ser recomendadas pelos normativos do Suas, como as casas de passagem.

A modalidade de SAIs mais frequente em todo o período analisado é a de abrigo, contemplando 2.066 serviços $(71,8 \%)$ em $2018 .{ }^{50}$ Casas-lares têm gradualmente crescido enquanto modalidade de SAIs, respondendo em 2018 por 763 serviços (26,5\%), maior proporção observada no período analisado (gráfico 13). A modalidade outros inclui uma série de possibilidades de organização do SAI, sendo a mais comum a casa de passagem - utilizada para permanência de curtíssima duração. Embora fossem tão frequentes quanto as casas-lares em 2010, a modalidade da casa de passagem não foi contemplada nas Orientaçóes Técnicas (Brasil, 2009) e deixou de ser identificada enquanto tal pelo Censo Suas, a partir de 2015.

47. Para que o atendimento em serviços de abrigo institucional possibilite à criança e ao adolescente constância e estabilidade na prestação dos cuidados, vinculação com o educador/cuidador de referência e previsibilidade da organização da rotina diária, os educadores/ cuidadores deverão trabalhar, preferencialmente, em turnos fixos diários, de modo a que o mesmo educador/cuidador desenvolva sempre determinadas tarefas da rotina diária - por exemplo: preparar café da manhã; almoço; jantar; dar banho; preparar para a escola; apoiar as tarefas escolares; colocar para dormir; etc. -, sendo desaconselhável esquemas de plantão, caracterizados pela grande alternância na prestação de tais cuidados.

48. As casas-lares podem estar inseridas tanto na comunidade quanto em aldeias. Quando em aldeias, são dispostas em um mesmo terreno, ao redor de um núcleo central, compartilhando da mesma estrutura técnico-administrativa.

49. A atividade de "mãe social" foi regulamentada pela Lei no 7.644/1987.

50. 0 pico ocorreu em 2014 , quando alcançou 2.090 serviços $(74,9 \%)$. 
TABELA 13

Quantidade de abrigos - Brasil e Grandes Regiões

(Em \%)

\begin{tabular}{lccccc}
\hline Região & 2010 & 2012 & 2014 & 2016 & 2018 \\
\hline Centro-Oeste & 65,6 & 62,6 & 68,1 & 62,2 & 62,2 \\
Nordeste & 68,0 & 62,7 & 74,0 & 72,9 & 70,4 \\
Norte & 64,9 & 67,0 & 77,1 & 85,7 & 87,8 \\
Sudeste & 68,8 & 75,5 & 80,4 & 79,9 & 79,5 \\
Sul & 52,4 & 52,0 & 66,7 & 56,8 & 57,6 \\
Brasil & $\mathbf{6 4 , 2}$ & $\mathbf{6 6 , 4}$ & $\mathbf{7 4 , 9}$ & $\mathbf{7 2 , 0}$ & $\mathbf{7 1 , 8}$ \\
\hline
\end{tabular}

Fontes: Levantamento Nacional, 2010; e Censo Suas Acolhimento 2012, 2014, 2016 e 2018.

Ainda que o abrigo figure como a modalidade mais frequente em todas as regióes no período analisado, é possível identificar maior preferência por este, especialmente nas regióes Norte $(87,8 \%)$ e Sudeste $(79,5 \%)$. As casas-lares, por sua vez, são mais comuns nas regióes Sul $(41,2 \%)$ e Centro-Oeste $(34,9 \%)$.

TABELA 14

Quantidade de casas-lares - Brasil e Grandes Regiões

(Em \%)

\begin{tabular}{|c|c|c|c|c|c|}
\hline Região & 2010 & 2012 & 2014 & 2016 & 2018 \\
\hline Centro-Oeste & 11,1 & 27,9 & 26,5 & 35,3 & 34,9 \\
\hline Nordeste & 12,8 & 21,0 & 18,7 & 25,6 & 27,4 \\
\hline Norte & 10,3 & 13,0 & 9,9 & 11,6 & 8,3 \\
\hline Sudeste & 15,6 & 17,6 & 14,6 & 18,6 & 19,3 \\
\hline Sul & 26,3 & 40,1 & 28,3 & 41,8 & 41,2 \\
\hline Brasil & 17,5 & 24,6 & 19,5 & 26,4 & 26,5 \\
\hline
\end{tabular}

Fontes: Levantamento Nacional, 2010; e Censo Suas 2012, 2014, 2016 e 2018.

A análise dessas variaçóes deve, no entanto, ser ponderada pelo processo de aprendizagem dos gestores dos serviços em relação aos conteúdos veiculados nas Orientaçóes Técnicas (Brasil, 2009) e no processo de reordenamento. A própria regularidade no preenchimento do Censo Suas implementado a partir de 2012, assim como o nível de adesão do gestor do serviço aos processos de capacitação e disseminação das novas diretrizes, pode ter afetado a autoidentificação do serviço nos formatos previstos nas normativas. Em outras palavras, é possível que, com o passar dos anos, os gestores dos serviços aprendam cada vez mais a identificar as especificidades dos seus serviços no âmbito das normativas e registrá-las no Censo Suas, o que pode fazer com que um serviço antes declarado como abrigo seja posteriormente identificado como casa-lar, e vice-versa.

TABELA 15

Serviços de acolhimento, por modalidade e porte - Brasil (2018)

\begin{tabular}{lccccc}
\hline \multirow{2}{*}{ Porte } & \multicolumn{3}{c}{ Abrigos institucionais } & \multicolumn{2}{c}{ Casas-lares } \\
\cline { 2 - 5 } & UAs & $\%$ & UAs & 124 \\
Metrópole & 342 & 16,6 & 215 & 16,3 \\
Grande & 599 & 29,0 & 65 & 28,2 \\
Médio & 298 & 14,4 & 146 & 8,5 \\
Pequeno II & 443 & 21,4 & 213 & 19,1 \\
Pequeno I & 384 & 18,6 & 763 & 27,9 \\
Brasil & 2.066 & 100,0 & 100,0 \\
\hline
\end{tabular}

Fonte: Censo Suas 2018. 
Ao se analisar as modalidades de acolhimento sob o critério do porte dos municípios, também é possível identificar algumas preferências, ainda que tênues. Os abrigos estáo um pouco mais concentrados nos municípios de grande porte (29\%), que também concentram parte importante das casas-lares $(28,2 \%)$. Municípios de pequeno porte I respondem também por outra parte importante das casas-lares $(27,9 \%)$.

\subsection{SAls por capacidade de atendimento e nível de lotação}

Vimos que, no período analisado, o reordenamento dos serviços de acolhimento - prestados em sua maior parte na forma institucional $(95,8 \%)$ - tem permitido a ampliação de serviços $(+9,6 \%)$, mesmo que com discreta redução de vagas $(-3,7 \%)$ e mais importante diminuição de acolhidos $(-15,3 \%)$. Tais resultados vão ao encontro tanto das diretrizes da excepcionalidade e provisoriedade da medida de acolhimento, quanto da oferta em pequenos grupos, ambas previstas no PNCFC. Cabe, no entanto, investigar o quanto esse novo perfil dos serviços de acolhimento se apresenta nas suas duas principais modalidades (abrigo e casa lar) e em que medida avançamos no enfrentamento do problema da superlotaçáo que durante tanto tempo caracterizou sua oferta (Silva, 2004).

Considerando-se a redução no número de acolhidos e o aumento na quantidade de serviços, é de esperar-se que o número médio de acolhidos por serviço também tenha diminuído, independentemente de adotar-se a modalidade abrigo ou casa-lar. Isso é confirmado no gráfico 14, o qual mostra que a média nacional de acolhidos por SAIs tem caído gradualmente, passando de 15,2, em 2010, para 10,6, em 2018.

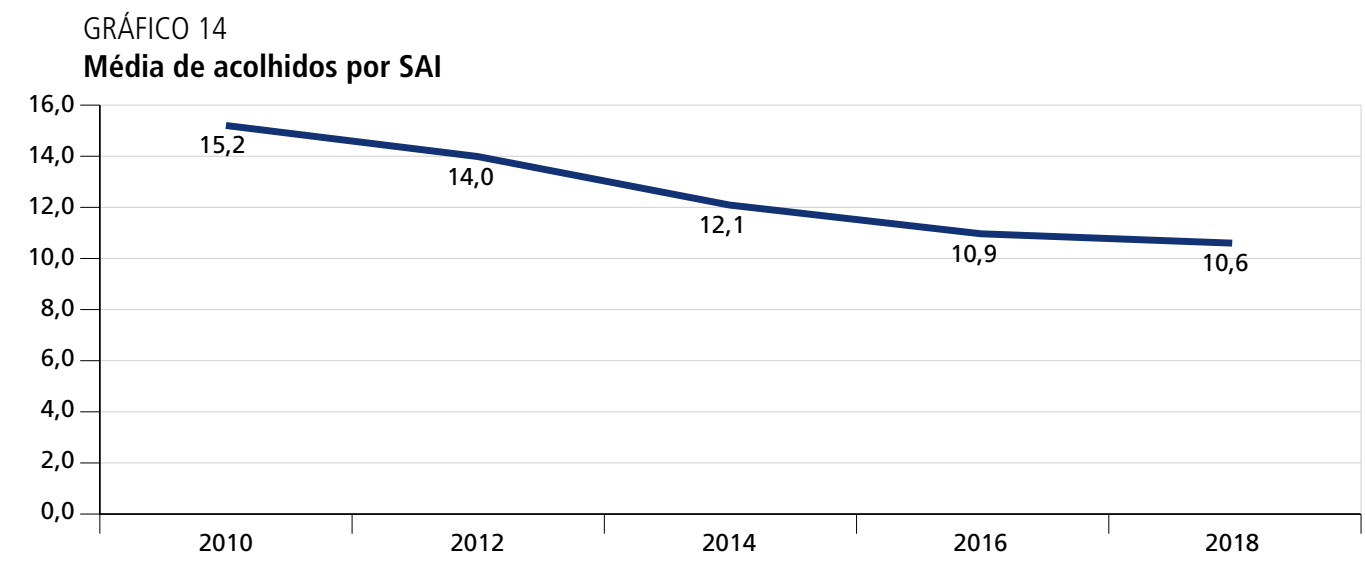

Fontes: Levantamento Nacional, 2010; e Censo Suas 2012, 2014, 2016 e 2018

Vale ressaltar que a redução no número médio de acolhidos por SAI já havia se iniciado entre 2010 e 2012 (de 15,2 para 14), logo após a publicação das Orientaçóes Técnicas (Brasil, 2009) e um pouco antes do incentivo financeiro ao processo de reordenamento, que apenas ocorreu a partir da Resolução no 23/2013. Essa constataçáo sugere que a definição de parâmetros nacionais para a oferta dos serviços já repercutia na sua realidade antes mesmo que os respectivos mecanismos de cofinanciamento fossem revistos.

A tabela 16 lança um olhar mais desagregado sobre a variável média de acolhidos por $S A I$, considerando tanto a capacidade máxima definida para a respectiva modalidade, quanto a região do país em que se encontra. 
TABELA 16

Média de acolhidos em SAI, por modalidade - Brasil e Grandes Regiões (2018)

\begin{tabular}{lcc}
\hline Grandes Regiões & Abrigos institucionais & Casas-lares \\
\hline Centro-Oeste & 9,1 & 10,2 \\
Nordeste & 13,0 & 9,0 \\
Norte & 10,4 & 8,8 \\
Sudeste & 11,7 & 7,8 \\
Sul & 12,0 & 8,2 \\
Brasil & $\mathbf{1 1 , 7}$ & $\mathbf{8 , 4}$ \\
\hline
\end{tabular}

Fonte: Censo Suas 2018

Nota-se que os SAIs de ambas as modalidades obedecem ao respectivo limite de acolhidos em todas as regióes. Em 2018, a média de acolhidos em abrigos no Brasil foi de 11,7, variando de 9,1, na regiáo Centro-Oeste, a 13, na regiáo Nordeste. Por sua vez, nas casas-lares, essa média foi de 8,4, oscilando entre 7,8 (no Sudeste) e 10,2 (no Centro-Oeste). Curiosamente, na regiáo Centro-Oeste, a modalidade casa-lar tem uma média de acolhidos por SAI $(10,2)$ no limite da sua previsão regulamentar, maior inclusive do que a média de acolhidos em abrigos $(9,1)$, o que merece ser melhor investigado. ${ }^{51}$ De qualquer forma, cabe registrar que os abrigos estáo, na prática, se aproximando das casas-lares quanto ao número de acolhidos; outra evidência dos resultados do reordenamento no sentido do atendimento em pequenos grupos.

Os parâmetros de no máximo dez vagas para a modalidade casa-lar e no máximo vinte vagas para a modalidade abrigo foram instituídos pelas Orientaçóes Técnicas (Brasil, 2009). A tabela 17 mostra a média de vagas ofertadas em SAIs, segundo a respectiva modalidade.

TABELA 17

Média de vagas em SAls, por modalidade - Brasil e Grandes Regiões (2018)

\begin{tabular}{lcc}
\hline Grandes Regiões & Abrigos institucionais & Casas-lares \\
\hline Centro-Oeste & 16,7 & 15,5 \\
Nordeste & 19,7 & 14,0 \\
Norte & 19,5 & 12,9 \\
Sudeste & 18,1 & 12,1 \\
Sul & 18,1 & 12,1 \\
Brasil & $\mathbf{1 8 , 3}$ & $\mathbf{1 2 , 7}$ \\
\hline
\end{tabular}

Fonte: Censo Suas 2018

Os abrigos oferecem em média 18,3 vagas, com alguma oscilação entre as regiōes. Por sua vez, a média de vagas ofertadas pelas casas-lares extrapola as dez vagas previstas para seu adequado funcionamento, tanto em nível nacional $(12,7)$ quanto em todas as regióes, em especial no Nordeste (14) e no Centro-Oeste $(15,5)$. Esse achado merece ser melhor investigado. Desenhadas para favorecer a criação e a manutenção de vínculos entre crianças e adolescentes e seus cuidadores, as casas-lares que oferecem acima de dez vagas podem estar comprometendo a qualidade do serviço prestado, ainda que na prática o número de

51. Entre as hipóteses explicativas para tanto, sugerimos a possiblidade de tratar-se do autorreconhecimento dos gestores da região sobre o serviço - com base na composição dos recursos humanos, e não no número de vagas, por exemplo -, além de situações excepcionais captadas por ocasião do preenchimento do Censo Suas, como o acolhimento de crianças e adolescentes com vínculo de parentesco (irmãos, primos, mãe e filho etc.). 
acolhidos esteja de acordo com o estabelecido nos regulamentos. Em que pese a necessidade de analisar tais peculiaridades das casas-lares, constata-se que a redução na média de acolhidos por serviço é mais uma evidência de duas tendências observadas neste relatório, de que tanto os novos serviços estão operando com capacidade inferior ao limite atribuído pelas Orientaçôes Técnicas (Brasil, 2009), como os "antigos" serviços estão sendo adaptados - e reduzidos - segundo tais parâmetros.

A discussão sobre vagas e acolhidos em SAIs, considerando-se a capacidade de atendimento para abrigos e casas-lares previstas nas Orientaçóes Técnicas (Brasil, 2009), traz à tona os problemas quanto ao nível de lotaçáo dos serviços. Um número de usuários superior à capacidade do equipamento dificulta e pode mesmo impedir a prestação adequada do serviço.

A pesquisa do Ipea e do Conanda (Silva, 2004) investigou o nível de lotação dos serviços de acolhimento para crianças e adolescentes. Naquela ocasiáo, em que a orientação nacional era de que cada serviço acolhesse, no máximo, 25 crianças e adolescentes, foi constatado que $56,7 \%$ dos serviços analisados cumpriam esse requisito, restando boa parte com lotação acima do recomendado. Esse limite de 25 crianças e adolescentes por serviço de acolhimento foi revisto na formulação das Orientaçôes Técnicas (Brasil, 2009), sendo desdobrado nas suas duas modalidades, fixando o máximo de vinte acolhidos para abrigo e dez para casas-lares.

O gráfico 15 sistematiza essa variável para o período 2010-2018.

\section{GRÁFICO 15}

Quantidade de SAls, segundo a relação entre a respectiva lotação e a capacidade adequada de atendimento ${ }^{1}$

(Em \%)

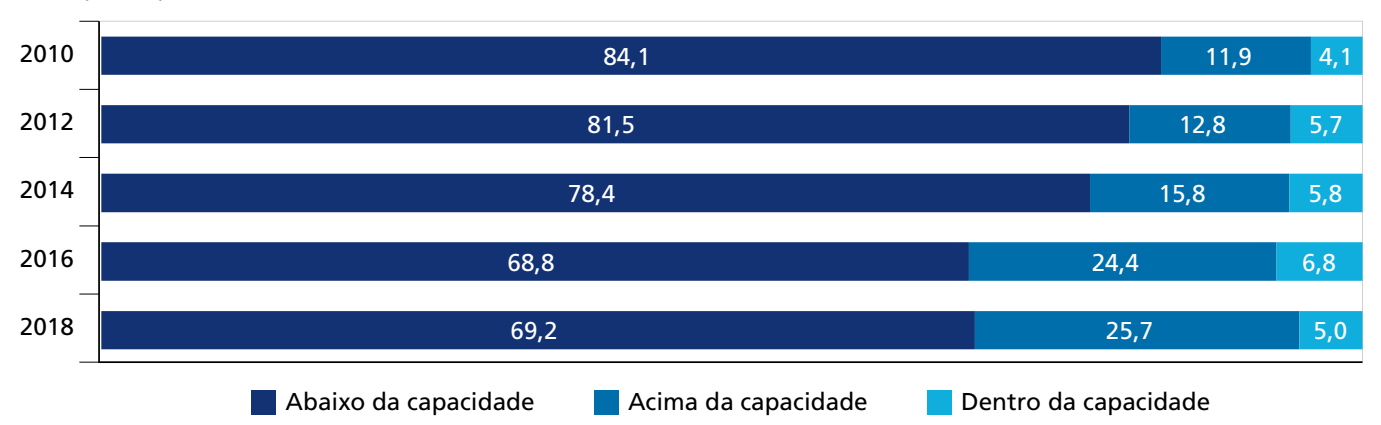

Fontes: Levantamento Nacional, 2010; e Censo Suas 2012, 2014, 2016 e 2018.

Nota: ' Segundo as diretrizes de Orientações Técnicas: serviços de acolhimento para crianças e adolescentes (Brasil, 2009).

Verifica-se redução na proporção de serviços que operam acima da respectiva capacidade sugerida pelas normativas, de 25,7\%, em 2010, para 11,9\%, em 2018. A quantidade do SAI que funciona abaixo da respectiva capacidade considerada adequada também tem aumentado gradualmente.

O gráfico 16 explora um pouco mais o perfil dos serviços que estão acima da respectiva capacidade adequada de atendimento, tal como sugerido pelas Orientaçóes Técnicas (Brasil, 2009). Os quais, como vimos anteriormente, representam uma parcela cada vez menor dos SAIs em funcionamento. 
GRÁFICO 16

SAls com número de acolhidos acima da capacidade adequada de atendimento ${ }^{1}$ - Grandes Regiões

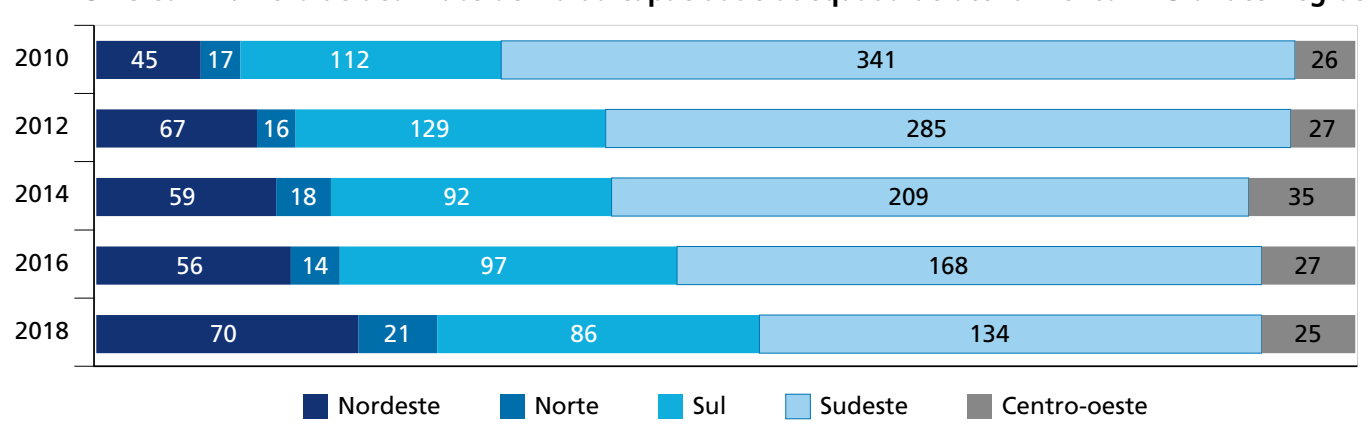

Fontes: Levantamento Nacional, 2010; e Censo Suas 2012, 2014, 2016 e 2018.

Nota: ${ }^{1}$ Segundo as diretrizes de Orientações Técnicas: serviços de acolhimento para crianças e adolescentes (Brasil, 2009).

Encontramos diferentes dinâmicas entre as regióes nesse aspecto. Em 2010, a região Sudeste respondia por mais da metade dos SAIs com lotação acima da respectiva capacidade (321 serviços ou 63\%); proporção que gradualmente foi se reduzindo até 2018 (168 serviços ou 39,9\%). Por sua vez, as demais regiōes ampliaram sua participação no total de SAIs com lotação acima da capacidade, com destaque para as regióes Nordeste - que passou de 45 (ou $8,3 \%$ ) para 75 (ou 20,8\% dos serviços) - e Norte - que passou de 17 (ou 3,1\%) para 21 ou $6,3 \%$ dos serviços com essa característica. Assim, além de a quantidade de serviços que operam acima da respectiva capacidade máxima de atendimento ter se reduzido em números absolutos (de 543 para 336), encontramos em 2018 uma distribuição regional mais equilibrada dos serviços nessa condição, em comparação ao início da série analisada (gráfico 16).

GRÁFICO 17

SAls com lotação acima da capacidade adequada de atendimento, ${ }^{1}$ por porte (Em \%)

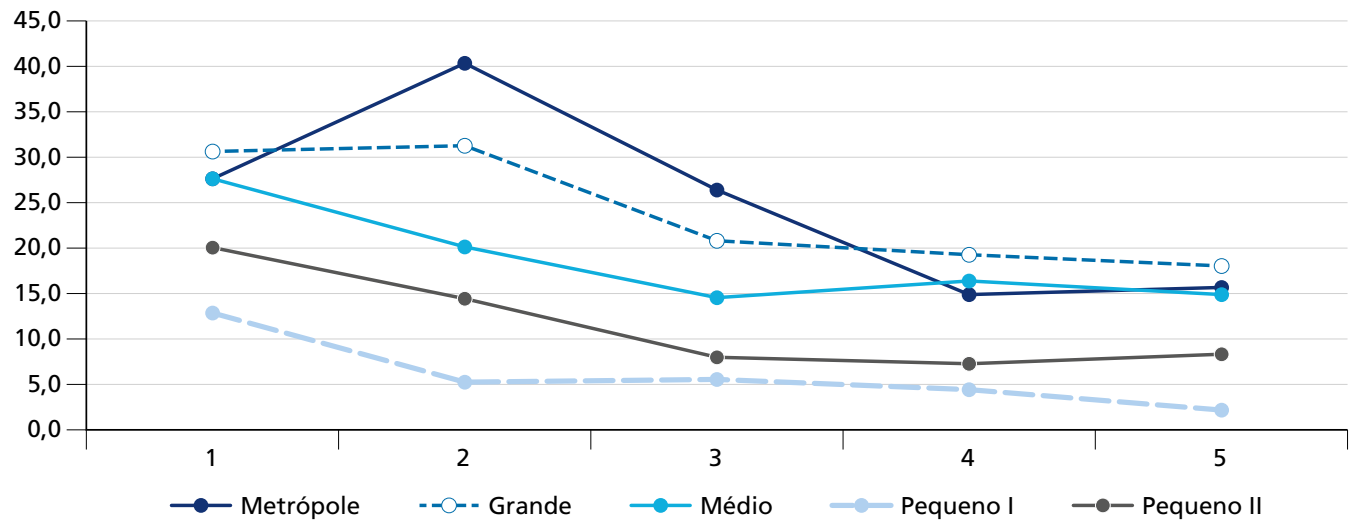

Fontes: Levantamento Nacional, 2010; e Censo Suas 2012, 2014, 2016 e 2018

Nota: ${ }^{1}$ Segundo as diretrizes das Orientações Técnicas: serviços de acolhimento para crianças e adolescentes (Brasil, 2009).

A análise dessa mesma variável (SAIs com número de usuários acima da respectiva capacidade de atendimento indicada) mostra que a tendência de queda no percentual de serviços com essa característica ocorreu em municípios de todos os portes, sendo mais intensa nos maiores, em especial nas metrópoles, que, embora tenham registrado $40 \%$ das unidades nessa situação em 2012, em 2018 computaram apenas 15,7\%. Essa constatação parece relacionar-se com a história da oferta desse serviço, que durante muito tempo esteve concentrado nas grandes 
cidades e guardava características de abrigamento de grandes grupos. Como o reordenamento aumentou o número de municípios com serviço de acolhimento, e com as diretrizes da proximidade da família de origem, espera-se que esse arranjo tenda a diminuir.

Outro indicador mais comum de superlotação em um serviço que oferta acomodação (cama) consiste em considerar o número de vagas informado pelo próprio estabelecimento e subtrair desse total o número de acolhidos informados. Se o resultado da subtração for menor que zero, identifica-se a unidade como superlotada, bem como todas as crianças e adolescentes ali residentes como pessoas acolhidas em unidade operando acima da sua capacidade. Embora possamos argumentar que nem sempre isso indica uma situaçáo alarmante - é possível que tenha se colocado uma cama extra em um quarto para abrigar melhor um conjunto de irmãos sem alterar oficialmente o número de vagas, por exemplo -, segue sendo verdade que o número máximo de vagas deveria ser respeitado. Como revela a tabela 18, em 2018, nada menos que $16 \%$ dos acolhidos estavam em unidades superlotadas.

TABELA 18

Número de crianças e adolescentes acolhidas, por lotação da unidade (2018) ${ }^{1}$

\begin{tabular}{lrrr}
\hline & SAl & SAF & Total \\
\hline Em unidades superlotadas & 5.195 & 0 & $\mathbf{5 . 1 9 5}$ \\
Em unidades com número de & 25.627 & 1.392 & $\mathbf{2 7 . 0 1 9}$ \\
acolhidos dentro do limite da lotação & 30.822 & 1.392 & 32.214 \\
Total & 16,9 & 0 & 16,1 \\
$\%$ & & & \\
\hline
\end{tabular}

Fonte: Censo Suas 2018.

Nota: ' Lotação da unidade entendida como a diferença entre o número de acolhidos superior ao número de vagas ofertadas, segundo autodeclaração da unidade. Algumas unidades foram excluídas da análise por falta de dados.

Resta inequívoca a redução dos serviços que operam acima do respectivo limite máximo, tal como definido pelas Orientaçóes Técnicas (Brasil, 2009). A ocorrência de serviços com essa característica também tem se reduzido em todos os portes de municípios, em especial nas metrópoles. Por sua vez, observa-se, em 2018, na perspectiva das macrorregióes do país, participação relativamente maior das regióes Nordeste $(8,3 \%$ para $20,8 \%)$ e Norte $(3,1 \%$ a 6,3\%) na distribuição dos serviços com essas características em relação ao praticado em 2010, o que pode indicar necessidade de ampliar-se ainda mais a oferta desses serviços nessas regióes, em função de demanda reprimida.

Todavia, até mesmo em contexto de redução gradual do número de acolhidos entre 2010 e 2018, além da redução substancial do problema da superlotação, o país segue enfrentando dificuldades nesse aspecto, as quais se manifestam com graus diferenciados segundo a perspectiva analisada. No caso dos serviços, $11,9 \%$ dos abrigos ou casas-lares operam acima da respectiva capacidade sugerida pelas normativas. Além disso, 16,1\% dos acolhidos (5.195) estão em serviços que declararam acolher mais usuários do que a respectiva quantidade de vagas disponibilizadas. O Censo Suas individualiza e permite o uso de diversas lentes para o diagnóstico da superlotação, a qual o poder público não pode se furtar em resolver, o que permanece como desafio a ser enfrentado no processo de atualizaçáo do PNCFC. 


\subsection{Período de criação e tempo de funcionamento dos SAls}

Vimos anteriormente que a proteçáo aos direitos da criança e do adolescente no Brasil conquistou diversos marcos institucionais orientadores de políticas públicas voltadas para esse público, os quais vão desde a criação do ECA, em 1990, passam pela publicação da Loas, em 1993, e da PNAS, em 2004, e pela criação do Suas em 2005. Além disso, há a própria publicação do PNCFC em 2006; a Tipificação Nacional dos Serviços Socioassistenciais e a definição de Orientaçóes Técnicas para o acolhimento institucional em 2009; e, finalmente, as estratégias de reordenamento e regionalização publicadas em 2013.

O gráfico 18 mostra a distribuição dos SAIs que participaram do Censo Suas de 2018, por ano de criação.

\section{GRÁFICO 18}

SAls criados a cada ano - Brasil (1989-2018) ${ }^{1}$

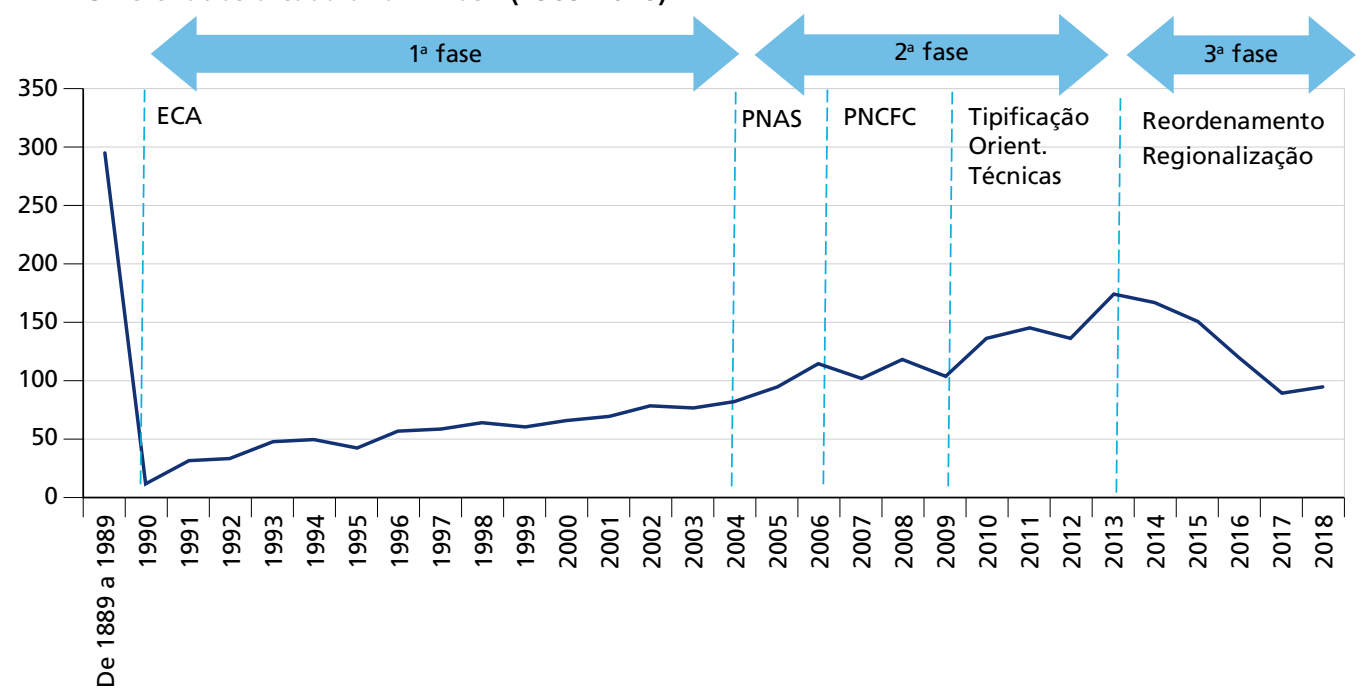

Fonte: Censo Suas 2018.

Nota: ${ }^{1} 0$ gráfico ilustra apenas os serviços de acolhimento em funcionamento em 2018 e não tem a intenção de mostrar a rotatividade das unidades. Ou seja, serviços que deixaram de existir não foram computados aqui.

Cerca de trezentos dos 2.877 SAIs em funcionamento em 2018 foram criados antes da publicação do ECA. Depois disso, a criação de novos serviços aumentou gradualmente, com pico em 2013, no qual teve início o processo de reordenamento e regionalização do serviço. A partir de entáo, a criaçáo de novas unidades de acolhimento continuou, mas em ritmo bem menor. Nesse sentido, é possível identificar três fases na trajetória do serviço de acolhimento institucional, descritas a seguir.

1) A primeira fase (1990-2003) de ampliação lenta, mas gradual, do acolhimento institucional a partir da publicação do ECA.

2) A segunda fase (2004-2013) de expansão mediante intensa criação de novos serviços, no bojo das mudanças institucionais que envolveram não apenas as definições contidas no PNCF em 2006, mas também a criação e a consolidação do Suas. O impacto da divulgação das Orientaçôes Técnicas (Brasil, 2009), assim como alteraçôes no ECA em dispositivos sobre convivência familiar e comunitária e serviços de acolhimento naquele mesmo ano (Pereira, Neris e Melo, 2019), também constituem marcos importantes que coincidem com picos de criação de novos serviços. 
3) A terceira fase de reordenamento e qualificação da oferta de SAIs até então adensada, mediante a qual a criação de novos serviços vem gradualmente dando lugar a um processo de adequação dos entáo existentes. Esse processo é impulsionado tanto pelos novos regulamentos, como as Orientaçóes Técnicas para a elaboraçáo do plano individual de atendimento (PIA) de crianças e adolescentes em serviços de acolhimento (Brasil, 2018), ${ }^{52}$ quanto pelos incentivos financeiros que buscaram materializar em sua estruturação e seu funcionamento os parâmetros nacionais pactuados pelos três níveis de governo na CIT, na forma das Resoluçōes no 23/2013 e no $31 / 2013$.

O gráfico 19 mostra que o acolhimento familiar possui uma trajetória mais errática de criação de novos serviços, com momentos de pico que coincidem com períodos próximos à publicação de regulamentos importantes na formatação deste, como a criação do PNCFC (2006), e nos anos em que o ECA recebeu importantes alteraçóes para seu funcionamento - como a determinaçáo da preferência do acolhimento familiar ao institucional, em 2009, e a possibilidade de uso do cofinanciamento federal para repasse de subsídios às famílias acolhedoras, em 2016 e $2017 .{ }^{53}$

GRÁFICO 19

SAFs em funcionamento, segundo ano de criação - Brasil

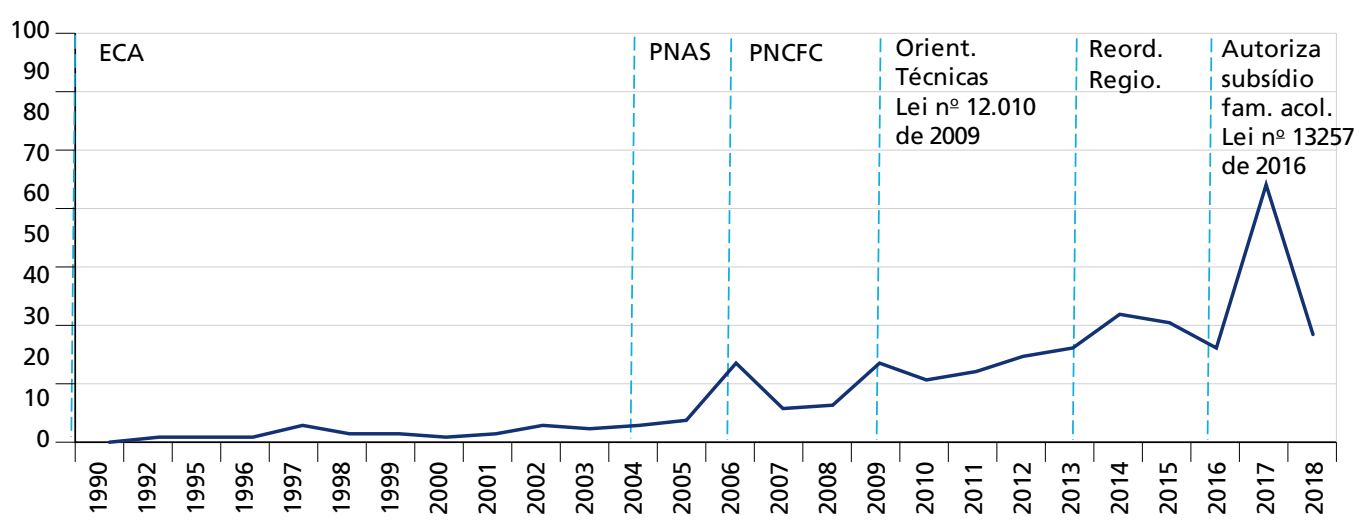

Fonte: Censo Suas 2018.

A maior parte dos SAIs apurados em 2018 (57,5\%) entrou em funcionamento há mais de doze anos, após, portanto, o advento do PNCFC (2006), razáo pela qual se deve esperar que as normativas posteriores tenham orientado sua trajetória de acordo com as diretrizes do referido plano. No entanto, menos de um terço dos serviços apurados em 2018 (27,7\%) possuía até cinco anos de funcionamento, tempo decorrido desde a publicação da estratégia de reordenamento em 2013 e a coleta do Censo Suas para o referido ano.

52. Disponivel em: <https://bit.ly/30As57i>.

53. 0 pico indicado em 2017 coincide com o momento em que se tornou obrigatório o preenchimento do sistema de cadastro do Suas (CadSuas), com o objetivo de que o SAF recebesse o cofinanciamento que permite o pagamento do subsídio para a família. Ou seja, caso não preenchesse o CadSuas, o serviço não poderia repassar o subsídio para a família. 
GRÁFICO 20

Tempo de funcionamento dos serviços de acolhimento (2018)

(Em \%)

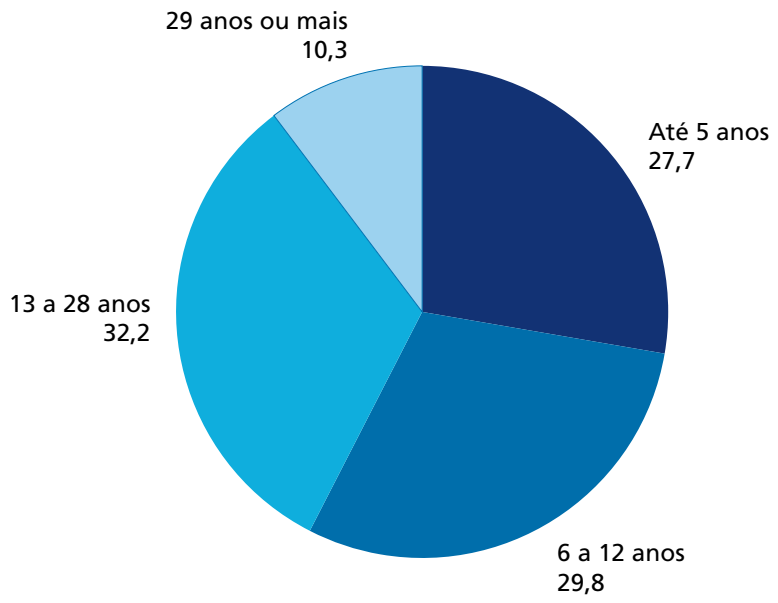

Fonte: Censo Suas 2018.

Relacionar o tempo de funcionamento dos serviços com parâmetros privilegiados no reordenamento dos serviços pode ajudar-nos a compreender em que medida os novos serviços criados já incorporam critérios importantes para a efetivaçáo do direito à convivência familiar e comunitária. Os próximos gráficos foram realizados com esse intuito, tendo como critério a média do número de vagas e acolhidos dos serviços.

GRÁFICO 21

Média de vagas por serviço em funcionamento, conforme o respectivo ano de criação

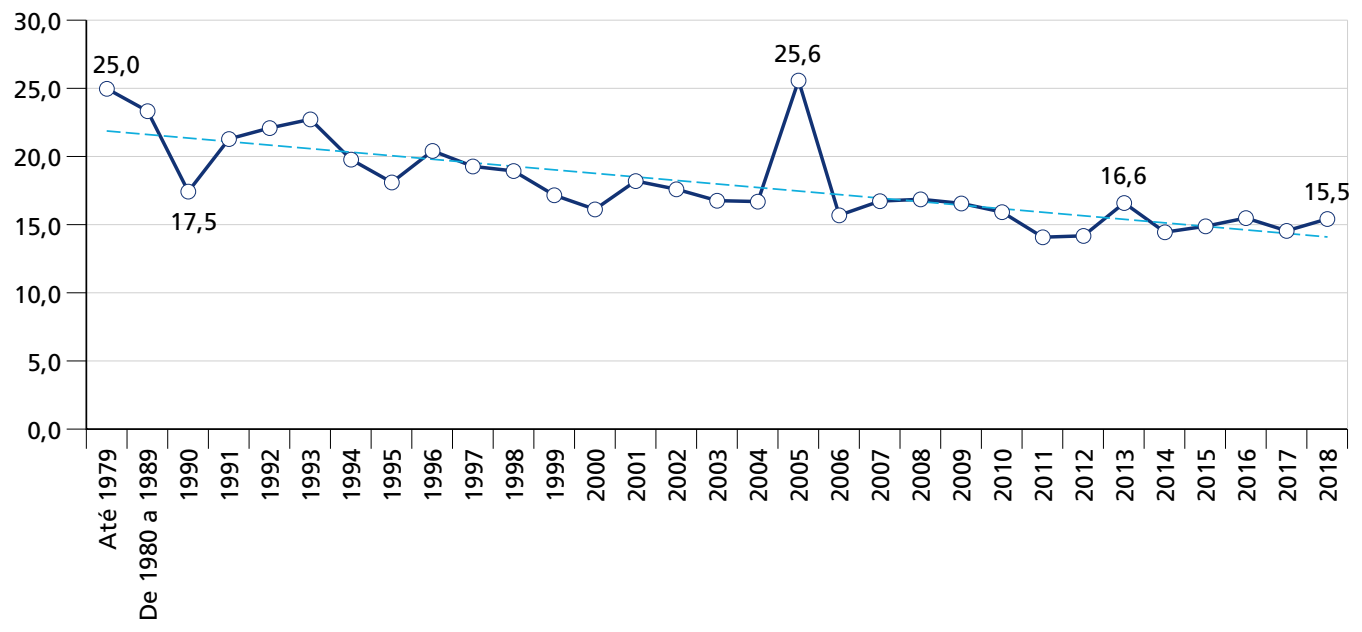

Fonte: Censo Suas 2018.

Em que pesem algumas variaçóes pontuais anuais, o gráfico 21 mostra uma tendência consistente de redução da média de vagas dos serviços criados após a publicação do ECA, que se estabilizou em torno de quinze vagas naqueles criados após a vigência das resoluçôes do reordenamento e regionalização, em 2013. 


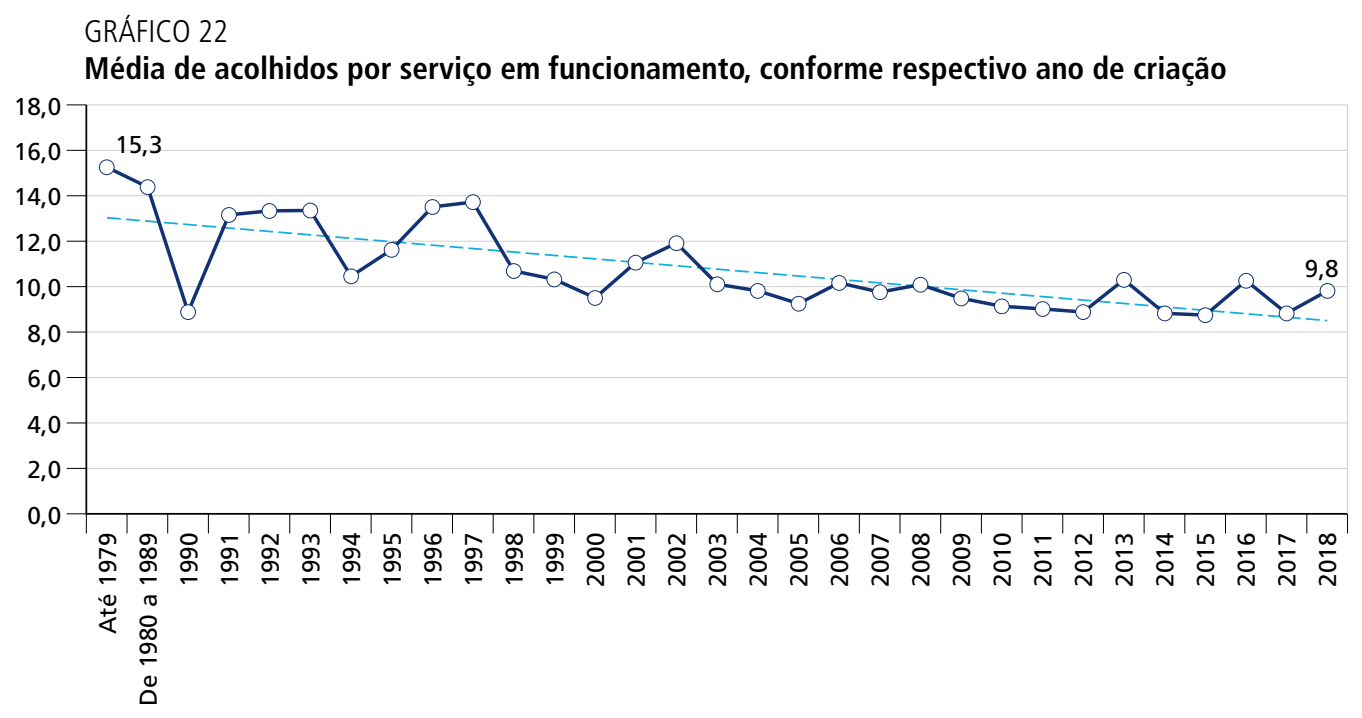

Fonte: Censo Suas 2018.

No caso da média de acolhidos - que é naturalmente inferior ao número de vagas -, o gráfico 22 evidencia que a tendência de redução também se faz presente, mas de maneira um pouco mais tênue. Essa redução sai de patamar de 15,3 para os serviços criados na década de 1990 para a média de dez acolhidos naqueles SAIs criados a partir do reordenamento e da regionalização em 2013, valor próximo de 14 nos serviços criados na década de 1990.

Outra forma de verificar em que medida os serviços criados mais recentemente oferecem menores quantidades de vagas e acolhem menor número de crianças e adolescentes é comparando a respectiva média de serviços criados antes e depois da publicação das Orientaçóes Técnicas em 2009 (Brasil, 2009), ano em que também houve alteração no ECA sobre convivência familiar e comunitária e serviços de acolhimento (Pereira, Neris e Melo, 2019). O gráfico 23 mostra diferenças importantes que sinalizam o impacto dos regulamentos que, após o PNCFC, orientaram o reordenamento dos serviços de acolhimento. Tanto a média de acolhidos quanto as vagas disponibilizadas nos serviços criados até 2009 sáo superiores aos daqueles criados a partir de 2010, para todas as apuraçóes no Censo Suas analisadas neste relatório.

GRÁFICO 23

Média de acolhidos por serviços até 2009 e a partir de 2010

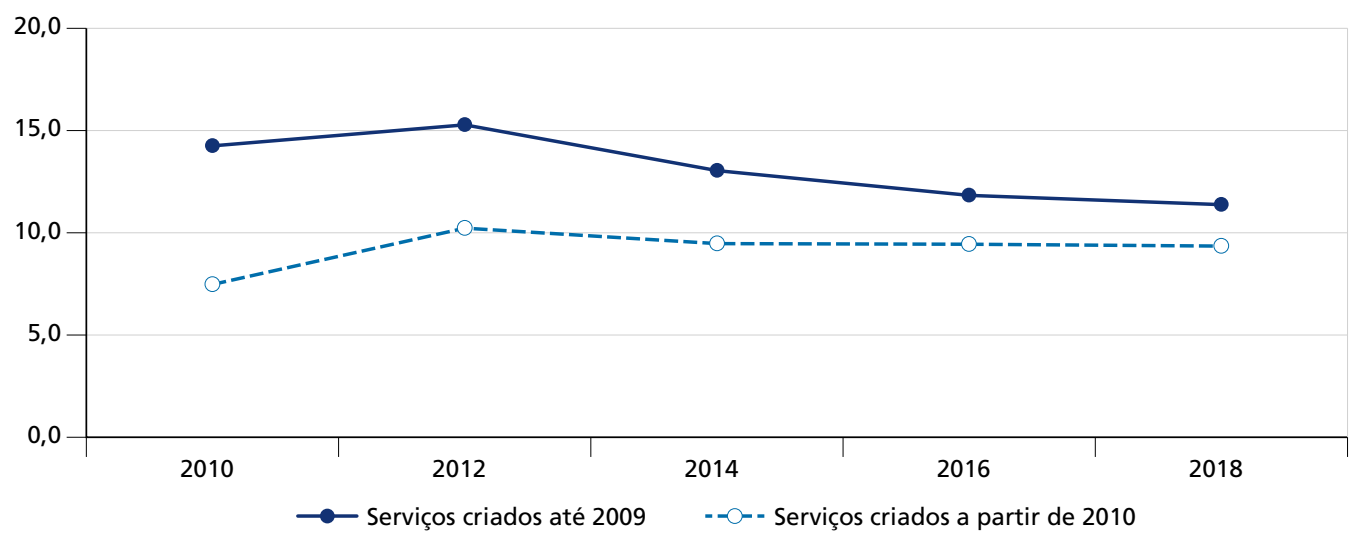


GRÁFICO 24

Média de vagas ofertadas por serviços criados até 2009 e a partir de 2010

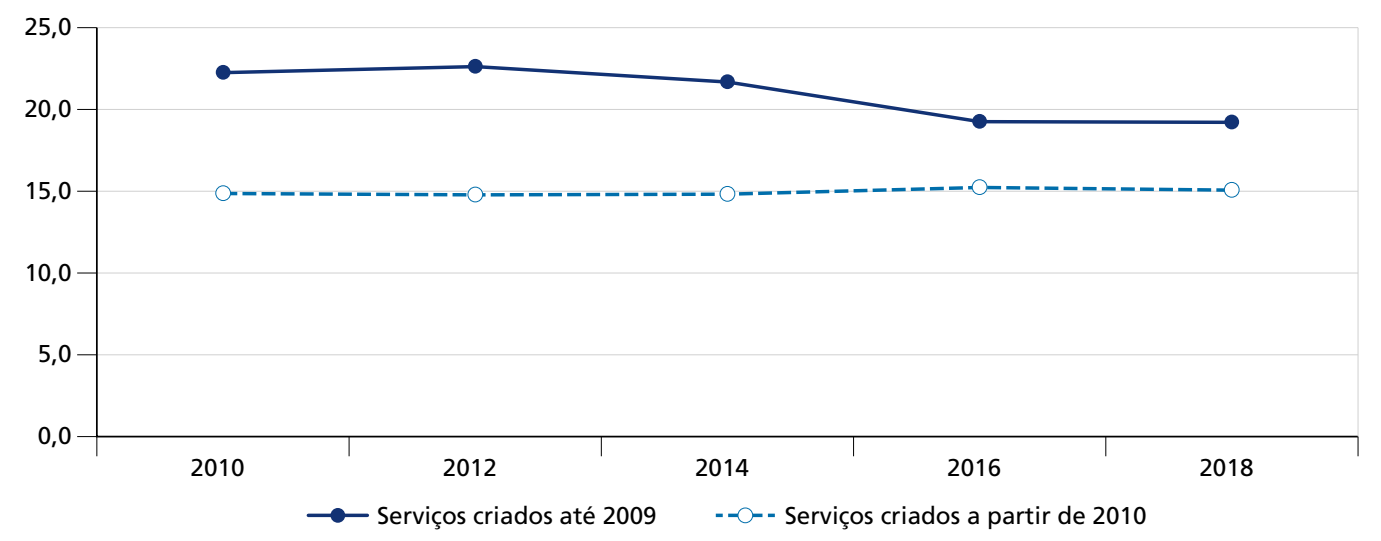

Fontes: Levantamento Nacional, 2010; e Censo Suas 2012, 2014, 2016 e 2018.

O gráfico 25 traz os serviços regionalizados de acolhimento sob gestão estadual em 2018, segundo o respectivo tempo de funcionamento.

GRÁFICO 25

Tempo de funcionamento dos serviços estaduais regionalizados (2018)

(Em \%)

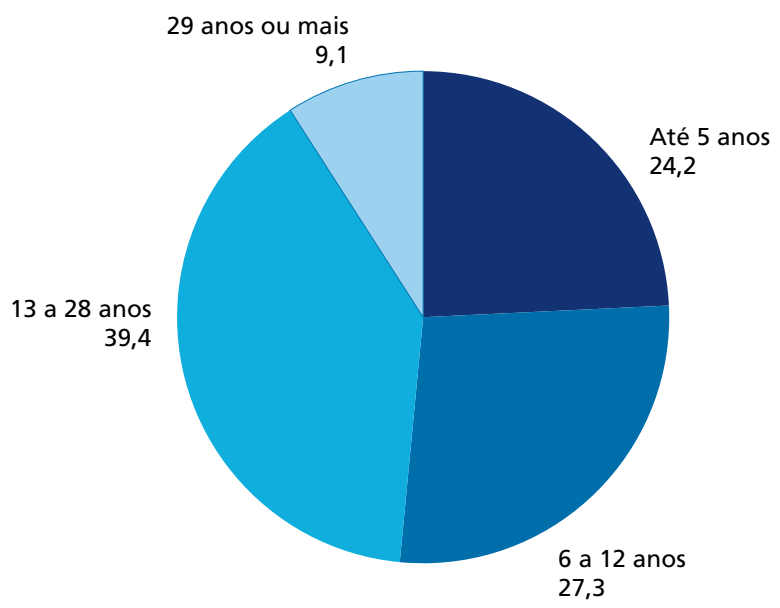

Fonte: Censo Suas 2018.

No caso dos serviços estaduais apurados em 2018, parte significativa possuía mais de treze anos de tempo de funcionamento $(48,5 \%)$, sendo, portanto, posteriores à publicação do PNCFC (2006) e dos demais regulamentos que reordenaram esses serviços. 
GRÁFICO 26

Média de acolhidos por serviço estadual em funcionamento, conforme respectivo ano de criação

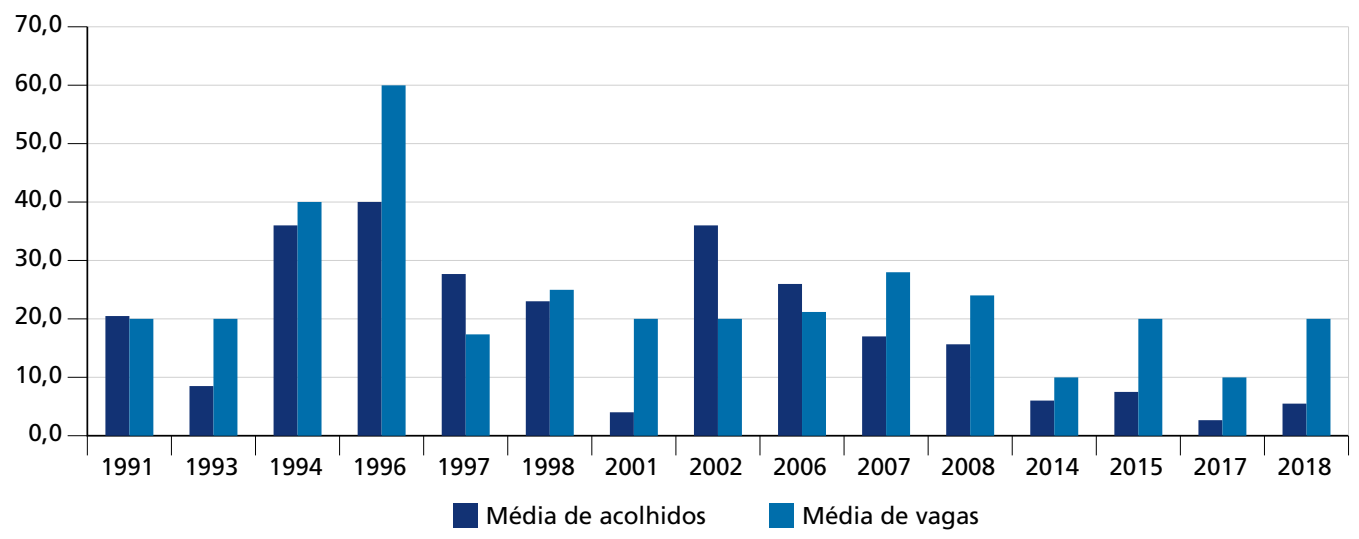

Fonte: Censo Suas 2018

O gráfico 26 mostra os serviços estaduais de acolhimento em funcionamento em 2018, no qual é possível constatar que a média de vagas e, principalmente, de acolhidos nos serviços estaduais criados mais recentemente são menores que nos serviços mais antigos. De fato, os serviços mais recentes têm buscado respeitar a diretriz de oferta em pequenos grupos.

\subsection{Serviços de acolhimento por natureza institucional}

O legado de elevado número de entidades - denominadas organizaçóes da sociedade civil $^{54}$ - responsáveis pela oferta de serviços socioassistenciais tem deixado marcas na política como um todo, sendo

(...) reflexo do histórico brasileiro de institucionalização da infância, em que o acolhimento de crianças e adolescentes era feito por entidades filantrópicas e religiosas, mantendo-se ainda hoje o ideário caritativo e assistencialista. Só mais tarde o Estado interviu (sic) nesta problemática, legislando sobre a questão e regulando seu funcionamento (Assis e Farias, 2013, p. 90).

Essa realidade também foi alterada com avanços legislativos ${ }^{55}$ e na gestão do Suas relacionados à oferta de serviços socioassistenciais pelas OSCs. Vale ressaltar que o modelo de parceria com essas organizaçóes adotado no Suas - cuja oferta é de natureza pública não estatal - confere ao poder público o comando central, com regras e parâmetros que devem ser observados na oferta dos serviços de acolhimento. Longe, portanto, de significar uma "desresponsabilização do Estado", que mantém importante parte do cofinanciamento, ${ }^{56}$ além da regulamentação do serviço. O gráfico 27 evidencia uma mudança gradual, porém consistente, no sentido da ampliação da oferta governamental do serviço, que, de 45,9\% em 2012, alcançou 53\% em 2018.

54. A Lei no 13.019/2014 (art. 2을 inciso I) especifica as características das entidades filantrópicas, confessionais, privadas ou cooperativas que são reconhecidas como OSCS. No Censo Suas, as organizações que ofertam os serviços ainda são identificadas como não governamentais. Nesse documento, adotamos a denominação atribuída em lei.

55. Marco regulatório instituído pela Lei no 13.019, de 31 de julho de 2014.

56. Vale lembrar que nem toda OSC que responde ao Censo Suas recebe recursos públicos. Nesse sentido, consideramos que, para compreender melhor a natureza institucional predominante dos serviços de acolhimento de crianças e adolescentes, seria importante admitir, ainda, a quantidade de unidades que, enquanto OSCs, recebem recurso do poder público, o que não foi possível neste relatório. 
GRÁFICO 27

Quantidade de SAls por natureza institucional - Brasil ${ }^{1}$ (Em \%)

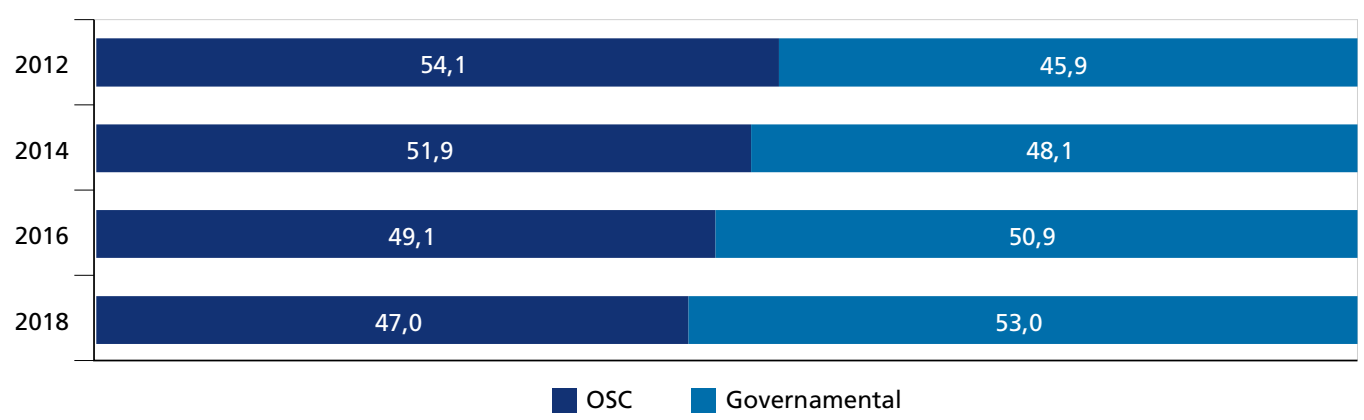

Fontes: Levantamento Nacional, 2010; e Censo Suas 2012, 2014, 2016 e 2018.

Nota: ' Excepcionalmente neste gráfico, não utilizamos 2010 como linha de base, dado que a base de dados do Levantamento Nacional da Fiocruz/MDS apresentava uma quantidade significativa de missings para essa variável.

No caso do acolhimento familiar, a natureza institucional mais comum no período analisado tem sido a governamental, com apenas $6 \%$ dos SAFs funcionando sob gestão de OSCs em 2018.

As situaçóes de oferta governamental ou por meio de OSCs diferem entre as regióes, conforme evidenciado pelo gráfico 28, que traz dados de 2018. Como já havia sido sinalizado na pesquisa do Ipea e do Conanda (Silva, 2004), as OSCs permanecem como as mais comuns na regiáo Sudeste $(58,6 \%)$. A regiáo Norte é a que possuía menor proporçáo de OSCs responsáveis pela oferta do serviço $(17,9 \%)$ nesse ano.

\section{GRÁFICO 28}

Quantidade de SAls por natureza institucional - Grande Regiões (2018)

(Em \%)

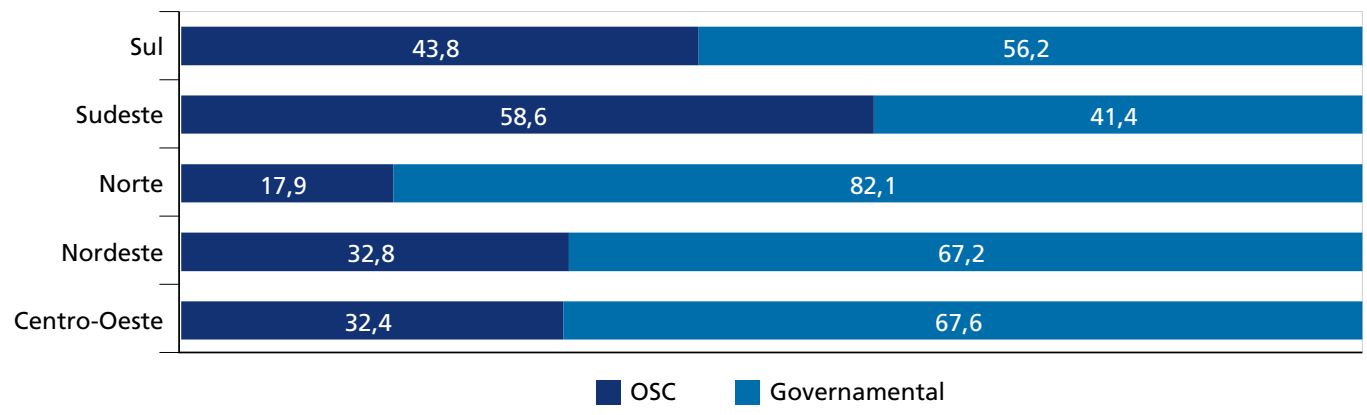

Fonte: Censo Suas 2018

Nota-se que, em 2018, a oferta por meio de OSCs era mais presente nos municípios mais populosos, enquanto a oferta governamental era mais relevante nos municípios menores. A tabela 19 mostra que, apesar de 0,3\% dos municípios serem considerados metrópoles, estas respondiam por cerca de 30\% dos serviços operados por OSCs. Por sua vez, apesar de $89,1 \%$ dos municípios no Brasil serem de pequeno porte I e II, apenas 22,9\% das OSCs ficam nesses municípios. 
TABELA 19

Quantidade de SAls, por natureza institucional e porte (2018) (Em \%)

\begin{tabular}{lccc}
\hline Porte populacional & Participação no total de municípios & OSC & Governamental \\
\hline Metrópole & 0,3 & 30,8 & 4,1 \\
Grande & 4,8 & 36,0 & 22,3 \\
Médio & 5,8 & 10,3 & 14,9 \\
Pequeno II & 18,7 & 14,4 & 26,2 \\
Pequeno I & 70,4 & 8,5 & 32,4 \\
Brasil & $\mathbf{1 0 0 , 0}$ & $\mathbf{1 0 0 , 0}$ & $\mathbf{1 0 0 , 0}$ \\
\hline
\end{tabular}

Fonte: Censo Suas 2018.

Outra forma de analisar esse dado é por meio do conjunto dos serviços disponíveis em cada porte, sob o critério da natureza institucional. A tabela 20 sugere uma correlação positiva entre o porte do município e a oferta de SAIs por OSCs. Ou seja, quanto mais populoso o município, maior a representatividade das ofertas públicas não estatais (OSCs) no conjunto dos serviços. De fato, a história mostra-nos que a institucionalização de crianças começou em capitais e centros urbanos, conduzida pelas entidades filantrópicas e confessionais (Silva, 2004). Foi apenas com o reordenamento do serviço no âmbito do Suas que a oferta pública governamental parece ter se ampliado. É provável que em muitos dos municípios menores e em regiôes como Norte e Nordeste, com menor presença de OSCs, a oferta governamental seja a única opção existente.

TABELA 20

Quantidade de SAls, por porte e natureza institucional (2018) (Em \%)

\begin{tabular}{lccc}
\hline Porte populacional & Governamental & OSC & Total \\
\hline Metrópole & 13,2 & 86,8 & 100,0 \\
Grande & 41,2 & 58,8 & 100,0 \\
Médio & 62,1 & 37,9 & 100,0 \\
Pequeno I & 81,1 & 18,9 & 100,0 \\
Pequeno II & 67,3 & 32,7 & 100,0 \\
Brasil & 53,0 & 47,0 & $\mathbf{1 0 0 , 0}$ \\
\hline
\end{tabular}

Fonte: Censo Suas 2018.

Enfim, ainda que tenham importância histórica enquanto legado absorvido pelo Suas a partir da definição de um marco regulatório que manteve o caráter público da oferta prestada pelas OCSs -, o movimento de reordenamento tem provocado uma inflexão na natureza institucional dos SAIs. Em 2018, a maior parte dos serviços eram ofertados por serviços governamentais (53\%), mais frequentes em municípios de médio e pequeno porte. Os serviços geridos por OSCs, tradicionalmente concentrados nos grandes centros urbanos, permaneceram mais frequentes nos municípios mais populosos.

\subsection{SAls por vinculação religiosa}

Como vimos na subseção anterior, os cuidados com os órfãos e os abandonados no Brasil foram assumidos pelas irmandades e pelas santas casas de misericórdia desde o final do século XVIII, 
Apenas no início do século XX, essa questão passou a ser uma preocupação de Estado, quando foram criados os reformatórios ou institutos correcionais. Ainda assim, a ação estatal era mais voltada para os "infratores" do que para os "carentes e abandonados". Além disso, as religióes costumam se envolver, em maior ou menor grau, em atividades voluntárias, destacando-se as atividades assistenciais (Silva, 2004, p. 77).

Vale lembrar que, segundo as Orientaçóes Técnicas (Brasil, 2009), não é proibido que o serviço tenha orientação religiosa, o que o documento reafirma como uma de suas diretrizes é a liberdade de crença e religiáo dos acolhidos - ou seja, que a opçáo por determinada religião seja imposta à criança ou ao adolescente que seja atendida por esse serviço. Dessa forma, em respeito inclusive ao art. 16, inciso III do ECA - o qual assegura a liberdade de crença e culto religioso - e considerando os princípios elencados pelas Orientaçóes Técnicas, o serviço tem de permitir e dar condiçóes para a preservação das crenças e da religião de cada acolhido, respeitando seus antecedentes religiosos e propiciando a satisfação das necessidades de vida religiosa e espiritual enquanto acolhidos.

O processo de reordenamento dos serviços de acolhimento tem provocado uma mudança rápida nesse legado de prevalência das OSCs confessionais.

TABELA 21

Quantidade de SAls, por vinculação religiosa - Brasil e Grandes Regiões (Em \%)

\begin{tabular}{lccccc}
\hline Região & 2010 & 2012 & 2014 & 2016 & 2018 \\
\hline Centro-Oeste & 58,9 & 40,5 & 40,8 & 31,1 & 33,2 \\
Nordeste & 65,4 & 42,1 & 37,4 & 30,9 & 26,9 \\
Norte & 67,0 & 51,0 & 35,9 & 34,7 & 30,8 \\
Sudeste & 50,3 & 32,1 & 31,6 & 23,2 & 21,9 \\
Sul & 43,1 & 34,5 & 30,5 & 28,0 & 26,5 \\
Brasil & $\mathbf{5 1 , 2}$ & $\mathbf{3 5 , 4}$ & $\mathbf{3 3 , 0}$ & $\mathbf{2 6 , 7}$ & $\mathbf{2 5 , 2}$ \\
\hline
\end{tabular}

Fontes: Levantamento Nacional, 2010; e Censo Suas 2012, 2014, 2016, 2018.

Nota-se na tabela 21 ampla redução no percentual de unidades com vínculo religioso no Brasil, que caiu vertiginosamente (de 51,2\%, em 2010, para 25,2\%, em 2018). Essa redução é ainda mais severa se comparada ao encontrado na pesquisa Ipea-Conanda (Silva, $2004)$, na qual a ampla maioria dos abrigos $(67,2 \%)$ possuía vinculação ou orientação religiosa. A queda de unidades com essa característica repete-se em todas as regióes; fenômeno certamente relacionado ao avanço na criação de serviços governamentais. Em 2018, apenas as regióes Norte e Centro- Oeste possuíam mais de 30\% dos SAIs com vinculação religiosa.

TABELA 22

Quantidade de SAls com vinculação religiosa, por natureza institucional e nível de gestão - Brasil (Em \%)

\begin{tabular}{lcrrrr}
\hline Natureza institucional & Nivel de gestão & 2012 & 2014 & 2016 & 2018 \\
\hline \multirow{2}{*}{ Governamental } & Estadual & 0,4 & 0,0 & 0,3 & 0,7 \\
& Municipal & 20,6 & 23,1 & 24,0 & 28,2 \\
OSC & - & 79,0 & 76,9 & 75,7 & 71,1 \\
Total & & $\mathbf{1 0 0 , 0}$ & $\mathbf{1 0 0 , 0}$ & $\mathbf{1 0 0 , 0}$ & $\mathbf{1 0 0 , 0}$ \\
\hline
\end{tabular}

Fontes: Censo Suas 2012, 2014, 2016 e 2018. 
A tabela 22 mostra a vinculação religiosa segundo a natureza institucional dos SAIs para o período 2012-2018, evidenciando, inclusive, no caso de serviço governamental, se está sob gestão estadual ou municipal. Curiosamente, verificamos discreta ampliação de serviços sob gestáo municipal que declararam orientaçáo religiosa, ao mesmo tempo que se observa redução proporcional na declaração dessa característica nos serviços prestados pelas OSCs. O baixo percentual de serviços governamentais estaduais com orientaçáo religiosa torna difícil identificar qualquer tendência para esse nível de governo.

\section{SERVIÇOS DE ACOLHIMENTO EM REPÚBLICAS: 0 QUE SÃO E PARA QUEM SE DESTINAM}

A modalidade de acolhimento para jovens em repúblicas é um serviço socioassistencial de alta complexidade, previsto na Tipificação Nacional de Serviços Socioassistenciais do Suas. ${ }^{57}$ Nesse documento, as repúblicas são definidas como um serviço que oferece proteção, apoio e moradia subsidiada a grupos de pessoas maiores de 18 anos em estado de abandono, situaçáo de vulnerabilidade e risco pessoal e social, com vínculos familiares rompidos ou extremamente fragilizados e sem condiçôes de moradia e autossustentação. A modalidade de acolhimento do tipo república foi pensada para atender a diferentes segmentos populacionais, e, por essa razáo, o documento recomenda que sua oferta precisa ser flexível e adaptar-se conforme às demandas específicas do público a que se destina.

Particularmente para os jovens de 18 a 21 anos, a Tipificação Nacional dos Serviços Socioassistenciais define as repúblicas como a modalidade de acolhimento destinada àqueles desligados dos serviços de acolhimento para crianças e adolescentes, ou que se encontrem em outra situação que demandem esse serviço. Precisam ser organizadas em unidades femininas e masculinas e ofertadas pela rede de serviços do Suas para ambos os sexos, de acordo com a demanda local. Os princípios e as diretrizes dessa modalidade de acolhimento encontram-se detalhados nas Orientaçôes Técnicas (Brasil, 2009), em cumprimento à proposta de regulamentação prevista no PNCFC.

O quadro 1 traz uma síntese, não exaustiva, de orientaçôes e diretrizes que devem guiar a organização dos serviços de repúblicas para jovens. Como se nota, a proposta pedagógica pensada para esse serviço socioassistencial é extremamente inovadora. As questóes-chaves para sua efetividade sáo o fortalecimento da autonomia, do protagonismo e dos vínculos comunitários dos jovens egressos, além da necessidade da ampliação do acesso à educação e do aumento da qualificação profissional para os jovens conseguirem inserçáo remunerada no mercado de trabalho. Conforme foi concebida, a república contribui para o cumprimento do item VII do art. 92 do ECA, o qual estabelece que as entidades que desenvolvam programas de acolhimento familiar ou institucional devem realizar a preparaçáo gradativa para o desligamento. No entanto, as açóes previstas no âmbito da oferta desse serviço estão distantes de poderem ser realizadas apenas pelas unidades de acolhimento, conforme determinado no ECA. Trata-se, de fato, de projeto pedagógico a ser articulado e desenvolvido por toda a rede de serviços existentes nos municípios. No entanto, cabe registrar que o ECA, diferentemente do que faz no caso dos adolescentes em conflito com a lei, que inclui aqueles até 21 anos, não faz orientação expressa ${ }^{58}$ de medidas mais específicas para os egressos dos serviços de acolhimentos em função da maioridade.

57. Resolução no 109, de 11 de novembro de 2009.

58. Embora se possa aplicar de forma extensiva a essas situações a interpretação do parágrafo único do art. 2ํ do ECA, o estatuto não dispõe de forma expressa sobre direitos ou medidas específicas que possam ser aplicadas em prol da proteção e apoio a esses jovens. 
Em 2003, quando a pesquisa do Ipea (Silva, 2004, p. 203-204) entrevistou os dirigentes dos serviços de acolhimento para crianças e adolescentes, já se notavam as dificuldades, por parte das instituiçóes, do atendimento ao princípio de preparação gradativa para o desligamento. Entrevistados naquela ocasiáo, os trabalhadores dos serviços de acolhimento destacaram os desafios que enfrentavam para o cumprimento dos princípios do ECA, que, segundo eles, dependiam do acesso, nem sempre fácil - ou existente -, a outras políticas e serviços no município. Em relação ao desligamento obrigatório por maioridade, muitos dirigentes explicitaram total desacordo com esse princípio contido no estatuto. Sendo o acolhimento medida de proteção destinada a crianças e adolescentes, a idade máxima é 18 anos - idade que delimita a adolescência, segundo o ECA. Segundos os entrevistados, para cumprir o princípio de preparação gradativa para o desligamento, as instituiçóes deveriam ter condiçóes de promover as garantias necessárias para a vida do egresso fora da instituição, tais como renda; emprego; escolarização; moradia; e a criação de algum tipo de vínculo parental ou não na comunidade. As palavras a seguir proferidas por uma dirigente de instituição não governamental de acolhimento deixam claros os desacordos e as dificuldades enfrentadas na etapa do desligamento devido ao alcance da maioridade dos jovens acolhidos:

(...) é realmente muito cruel ter que desligá-los da instituição, sabendo que eles ficam desprotegidos de novo. Que máe, quando o filho completa 18 anos, o póe para fora de casa? Por isto eu não cumpro este princípio. Podem me colocar na rua junto com eles, mas eu não faço isso. Eles mesmos nos dizem: "a família acaba agora de novo pra nós?" Entáo têm coisas que eu questiono no Estatuto, questiono com uma experiência sofrida junto com as crianças (Relato de uma dirigente de serviço de acolhimento não governamental do Rio Grande do Sul, extraído de Silva, 2004, p. 204).

QUADRO 1

Síntese das orientações e diretrizes serviços de acolhimento em repúblicas

\begin{tabular}{|c|c|}
\hline $\begin{array}{l}\text { Público } \\
\text { prioritário }\end{array}$ & $\begin{array}{l}\text { Indicado para o acolhimento de jovens, entre } 18 \text { a } 21 \text { anos, em processo de desligamento de serviços de acolhimento para } \\
\text { crianças e adolescentes por terem completado a maioridade, porém que ainda não tenham conquistado a autonomia. } \\
\text { Além dessa descrição, na parte que trata das atribuições da equipe técnica, o documento destaca ainda que, "prefe- } \\
\text { rencialmente", os jovens a serem acolhidos em repúblicas deveriam ser aqueles que já estivessem exercendo alguma } \\
\text { atividade remunerada quando da sua transferência para esse serviço. }\end{array}$ \\
\hline $\begin{array}{l}\text { Características } \\
\text { principais do } \\
\text { atendimento }\end{array}$ & $\begin{array}{l}0 \text { atendimento deve favorecer a construção de projetos de vida e o fortalecimento do protagonismo, desenvolvendo } \\
\text { gradativamente a capacidade de o adolescente responsabilizar-se por suas ações e escolhas. O plano pedagógico } \\
\text { deve prever metodologia para privilegiar a construção e o fortalecimento de vínculos comunitários significativos, a } \\
\text { ampliação do acesso à educação e à qualificação profissional, bem como a progressiva autonomia do jovem. }\end{array}$ \\
\hline Localização & $\begin{array}{l}\text { De acordo com as demandas e os recursos locais, as unidades de repúblicas poderão estar localizadas em cada um } \\
\text { dos municípios que compartilharem a equipe, ou apenas no município-sede do serviço, uma vez que os acolhidos já } \\
\text { são maiores de } 18 \text { anos. Nesse último caso, deverão ser assegurados meios necessários à locomoção do jovem ao seu } \\
\text { município de origem, periodicamente, de modo a manter laços de convivência ali estabelecidos. }\end{array}$ \\
\hline $\begin{array}{l}\text { Atribuições da } \\
\text { equipe técnica }\end{array}$ & $\begin{array}{l}\text { Articular e viabilizar o acesso dos jovens em: i) programas, projetos e serviços nos quais possam desenvolver ati- } \\
\text { vidades culturais, artísticas e esportivas que propiciem a vivência de experiências positivas e favorecedoras de sua } \\
\text { autoestima; ii) programas de aceleração da aprendizagem, para os casos de grande distorção série-idade; e iii) cursos } \\
\text { profissionalizantes e programas de inserção gradativa no mercado de trabalho - como estágios, programas de ado- } \\
\text { lescente aprendiz etc. }\end{array}$ \\
\hline $\begin{array}{l}\text { Custo do } \\
\text { imóvel }\end{array}$ & $\begin{array}{l}\text { Os custos da locação do imóvel - no caso de imóvel alugado - e tarifas podem ser subsidiados e gradativamente as- } \\
\text { sumidos pelos jovens. As demais despesas podem ser cotizadas entre os moradores, com subsídio quando necessário. }\end{array}$ \\
\hline
\end{tabular}

Fonte: Brasil (2009) 
A proposta de criação de moradias subsidiadas no modelo de repúblicas, apresentada no PNCFC $^{59}$ e depois regulamentada pelo Suas, é essencial para enfrentar os desafios do desligamento pela maioridade dos jovens, para os quais o objetivo da reintegraçáo familiar não tenha sido alcançado, quer seja na própria família de origem, quer seja em família substituta. Do lado dos jovens, o desligamento pela maioridade traz de volta o sofrimento vivido no momento em que tiveram de ser afastados de suas famílias de origem para viver nos abrigos. Temem perder, mais uma vez, os laços e as afeiçóes construídas com as pessoas que convivem na instituição. Do lado das equipes técnicas dos serviços de acolhimento, as dificuldades são enormes para serem bem-sucedidas na tarefa de promoçáo da autonomia emocional e financeira dos jovens, sobretudo daqueles que passaram grande parte de suas vidas nas unidades de acolhimento.

Em grande parte, são jovens que podem encontrar maiores dificuldades para alcançar a autonomia, em razão da baixa escolaridade e da reduzida qualificação para o mercado de trabalho. Atreladas a essas questóes, existem ainda as dificuldades emocionais que podem resultar das vivências que levaram ao acolhimento, da permanência nesse serviço sem a perspectiva de retomada do convívio familiar, pela reintegração à família de origem ou adoção, do sofrimento com o desligamento do serviço e das pessoas que são seu referencial de vínculos e de pertencimento, comuns àqueles que passaram muito tempo institucionalizados, sobretudo se náo tiveram oportunidades ou reduzidas experiências de vinculaçáo significativa com familiares e pessoas da comunidade. Esse processo pode ser ainda mais complexo se o jovem teve poucas experiências em lidar com questóes simples do cotidiano de qualquer adolescente - por exemplo: ir a uma padaria comprar páo; ter uma quantia financeira própria para comprar suas próprias coisas, como roupas e sapatos; sentar a uma mesa para refeiçáo e servir seu próprio prato; ter um lugar exclusivo para guardar suas roupas ou materiais escolares etc. De acordo com Silva (1997), os danos causados pela institucionalização serão tanto maiores quanto maior for o tempo vivido na instituição, que interfere na adaptação das coisas mais básicas do cotidiano, ao longo da vida. Segundo esse autor, crianças que passam muito tempo institucionalizadas são "diferentes no exercício da sociabilidade, diferentes na expressão da afetividade, diferentes no rendimento escolar e diferentes nos hábitos e costumes também” (Silva, 1997, p. 13).

Como já dito anteriormente, a Resolução CNAS no 23/2013 aprovou os critérios de elegibilidade e partilha dos recursos do cofinanciamento federal para expansão qualificada dos serviços de acolhimento para crianças, adolescentes e jovens até 21 anos - isto é, desde 2013, existe a possibilidade do uso do recurso federal para o cofinanciamento das repúblicas. Inclusive, dos recursos disponibilizados hoje, este é o que paga um dos maiores valores por vaga. A expectativa é que a flexibilidade - o recurso pode ser gasto com abrigos, casa-lares, famílias acolhedoras ou repúblicas - fomentasse a criação de novas modalidades; em especial, as famílias acolhedoras e as repúblicas. No entanto, os dados analisados evidenciam que a oferta desses serviços é ainda incipiente no país, particularmente no caso das repúblicas. Uma das hipóteses é a do desconhecimento dessa possibilidade pelos gestores municipais; a outra é que, como são os mesmos recursos, os gestores reiteradamente optam pelos serviços de acolhimento de crianças e adolescentes em detrimento das repúblicas. Os motivos para isso 
são muitos: o entendimento de que crianças e adolescentes estão em vulnerabilidade; questôes políticas e de visibilidade; e até mesmo o fato de que há obrigaçóes impostas pelo Poder Judiciário para o acolhimento de crianças e adolescentes, o que não é extensivo às repúblicas.

Além de medidas que possam impulsionar a ampliação dessa oferta, a proteção aos adolescentes acolhidos e aos jovens egressos de serviços de acolhimento exige o delineamento de um conjunto mais ampliado de açóes voltadas ao suporte a suas demandas e ao desenvolvimento de sua autonomia. Nesse sentido, inserem-se, por exemplo, as açóes para a atenção à educação; a preparação e a inclusão no mundo do trabalho; o acesso à renda; o apoio emocional e psicológico; os cuidados com a saúde e o autocuidado; a construçáo de vínculos de referência para além do serviço de acolhimento; o acesso a alternativas de moradia para além das repúblicas e, no caso destas, com flexibilidade para compartilhamento por afinidade e escolha; etc.

Nessa direção, alguns municípios têm implementado estratégias que podem compor uma política mais estruturada e ampliada de proteção e apoio a esses adolescentes e jovens, como a inclusão em programas de aprendizagem, de apadrinhamento afetivo, a integração no Cadastro Único do Governo Federal (CadÚnico) como família unipessoal - a partir dos 16 anos - e no Programa Bolsa Família (PBF), o acesso a aluguel social etc. O desenvolvimento da autonomia deve, ainda, integrar os projetos políticos pedagógicos dos serviços de acolhimento e o PIA nas diferentes faixas etárias, de forma contínua e progressiva. Algumas situaçóes podem exigir o delineamento de açóes ainda mais específicas, como no caso de adolescentes com deficiência mental que atinjam a maioridade no serviço de acolhimento. Algumas dessas escolhas são vistas pelos gestores municipais como alternativas às repúblicas; no entanto, é necessário produzir mais informaçóes e Orientaçóes Técnicas para ter certeza de que a saída desses jovens dos acolhimentos está se dando da forma mais segura e garantidora de direitos.

\subsection{Um retrato dos serviços de acolhimento em repúblicas}

Em 2018, somente dezenove municípios no Brasil inteiro ofertavam serviços de acolhimento em repúblicas. No total, eram trinta serviços distribuídos em apenas nove estados e três regióes. O Censo Suas 2018 não encontrou nenhum serviço de acolhimento em repúblicas nas regióes Norte e Centro-Oeste. A ilustração do mapa do Brasil (mapa 3), indicando a localização das repúblicas para jovens no país, retrata a realidade de total ausência de alternativas de moradias para os jovens egressos que completam 18 anos na maior parte dos municípios do país. Entre os dezenove municípios que ofertam os serviços de acolhimento em repúblicas, dez são de grande porte, seis são metrópoles, dois são de médio porte e um município é classificado como de pequeno porte II. 

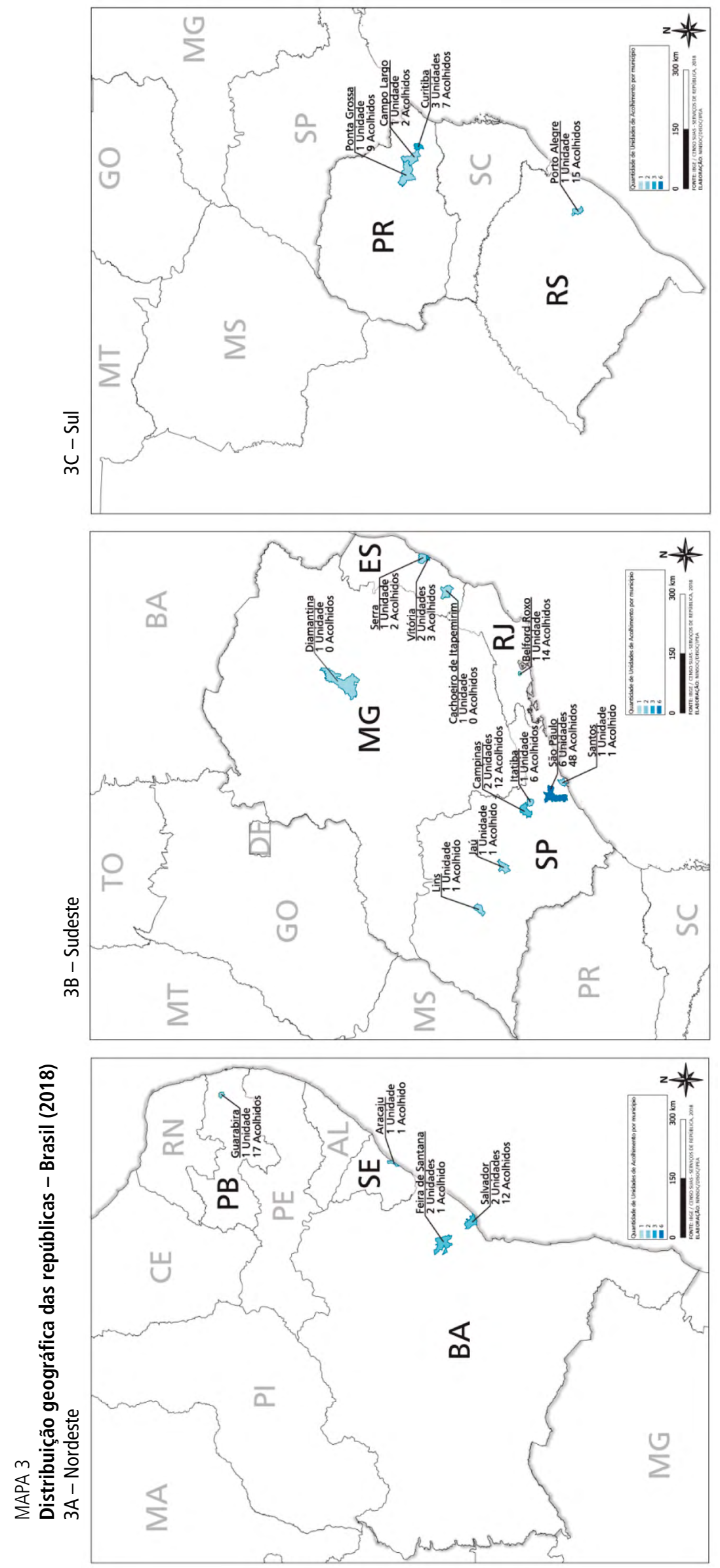
Conforme detalhado anteriormente (quadro 1), quando não existir demanda suficiente no próprio município que justifique a instalaçáo das repúblicas, essa modalidade de acolhimento pode estar instalada apenas no município-sede do serviço, uma vez que os acolhidos, por serem maiores de 18 anos, já têm autonomia para o deslocamento entre os municípios. Nesse caso, os meios necessários à locomoção do jovem ao seu município de origem precisam ser assegurados para que os laços de convivência ali estabelecidos sejam mantidos. $\mathrm{Na}$ realidade, o país está muito distante de atender a essa recomendação, como ilustra o mapa 3.

A tabela 23 detalha um pouco mais a oferta de serviços de repúblicas no país. Em 2018, existiam trinta unidades desses serviços no Brasil, os quais ofertavam 244 vagas e atendiam 152 jovens de 18 a 21 anos, sendo 45 mulheres e 107 homens. Do total de unidades, seis estavam localizadas em três estados da regiáo Nordeste (Bahia, Sergipe e Paraíba). Os demais estados do Nordeste não ofertavam esses serviços em 2018. A regiâo Sudeste tinha dezoito unidades distribuídas entre os estados do Espírito Santo, de Minas Gerais, do Rio de Janeiro e de São Paulo, sendo que este último concentrava doze unidades, quase metade das repúblicas existentes em todo o Brasil. A regiáo Sul tinha seis unidades localizadas nos estados do Paraná e do Rio Grande do Sul. No estado de Santa Catarina, o Censo Suas não encontrou nenhum serviço de repúblicas. Nenhum dos estados da região Norte e Centro-Oeste ofertava esse tipo de serviço.

TABELA 23

Repúblicas para jovens egressos de medida de proteção de acolhimento: municípios, vagas e acolhidos por sexo - Brasil e Grandes Regiões (2018)

\begin{tabular}{|c|c|c|c|c|c|c|}
\hline \multirow{3}{*}{ Regiões } & \multicolumn{6}{|c|}{2018} \\
\hline & \multirow{2}{*}{ № de municípios } & \multirow{2}{*}{ Total de Unidades } & \multirow{2}{*}{ Total de Vagas } & \multicolumn{3}{|c|}{ № de Acolhidos } \\
\hline & & & & Total & Mulheres & Homens \\
\hline Nordeste & 4 & 6 & 58 & 31 & 4 & 27 \\
\hline Bahia & 2 & 4 & 32 & 13 & 0 & 13 \\
\hline Sergipe & 1 & 1 & 6 & 1 & 0 & 1 \\
\hline Paraíba & 1 & 1 & 20 & 17 & 4 & 13 \\
\hline Sudeste & 11 & 18 & 139 & 88 & 31 & 57 \\
\hline Espírito Santo & 3 & 4 & 24 & 5 & 4 & 1 \\
\hline Minas Gerais & 1 & 1 & 6 & 0 & 0 & 0 \\
\hline Rio de Janeiro & 1 & 1 & 28 & 14 & 0 & 14 \\
\hline São Paulo & 6 & 12 & 81 & 69 & 27 & 42 \\
\hline Sul & 4 & 6 & 47 & 33 & 10 & 23 \\
\hline Paraná & 3 & 5 & 23 & 18 & 5 & 13 \\
\hline Rio Grande do Sul & 1 & 1 & 24 & 15 & 5 & 10 \\
\hline Centro-Oeste & 0 & 0 & 0 & 0 & 0 & 0 \\
\hline Norte & 0 & 0 & 0 & 0 & 0 & 0 \\
\hline Brasil & 19 & 30 & 244 & 152 & 45 & 107 \\
\hline
\end{tabular}

Fonte: Censo Suas 2018.

Como se observa, o total de vagas ofertadas pelos serviços de repúblicas existentes no Brasil é superior ao número de jovens acolhidos nessas moradias. Em 2018, os serviços ofertavam 244 vagas e existiam 152 acolhidos - ou seja, sobravam 92 vagas, cerca de 40\% estavam desocupadas. A revelaçáo sobre a elevada proporção de vagas ociosas nos serviços existentes seria, na primeira análise, uma notícia boa, pois estaria sinalizando que a oferta de serviços de repúblicas em 2018 seria suficiente para atender, com folga, à demanda dos jovens egressos. 
No entanto, a análise conjunta da ocupação das vagas existentes em 2018 com o total de jovens de 18 a 21 anos, que ainda estavam vivendo nas unidades de acolhimento para crianças e adolescentes, quando já deveriam estar morando em repúblicas, suscita duas outras hipóteses, não excludentes, que podem explicar a elevada subocupação das vagas. A primeira é que as repúblicas com vagas ociosas não se localizavam próximas aos municípios das unidades de acolhimento de crianças e adolescentes, onde se encontravam os jovens de 18 a 21 anos. A segunda hipótese refere-se às dificuldades enfrentadas pelas equipes técnicas nas tarefas de preparaçáo gradativa, dos adolescentes para a vida fora da instituição. Por não conseguirem prepará-los, eles precisavam continuar vivendo no abrigo institucional ou na casa-lar. Como mostrado anteriormente (quadro 1), há uma ideia de que as repúblicas devam ser ocupadas, preferencialmente, por jovens que já tenham alguma atividade remunerada no momento de sua transferência. Como, de forma geral, os jovens com trajetória de institucionalização e com histórico de violência, negligência e abandono enfrentam maiores desafios para o avanço da escolaridade e da qualificação para o mercado de trabalho, é possível que essa seja uma das razóes para ainda viverem nas unidades de acolhimento para crianças e adolescentes, até mesmo após a maioridade. Finalmente, a terceira hipótese, que precisa ser investigada por meio de pesquisa qualitativa, refere-se à reduzida atratividade das repúblicas por parte dos jovens egressos ou à baixa aderência da modalidade às demandas desses jovens, denotando a necessidade de aprimorar alternativas de suporte a esse grupo. Nesse caso, é possível que os jovens deem preferência a outras alternativas de moradia.

A tabela 24 reúne informaçóes um pouco mais detalhadas sobre o potencial de jovens que demandariam os serviços de repúblicas, as quais contribuem para aumentar o entendimento dessa questão. Além das informaçóes sobre o número de jovens de 18 a 21 anos que ainda estavam acolhidos em serviços de crianças e adolescentes em 2018, a tabela traz também o quantitativo de adolescentes de 16 a 17 anos acolhidos, por entender que esse grupo etário, por estar próximo do alcance da maioridade, pressionaria a demanda por serviços de república nos dois anos subsequentes à realização da pesquisa pelo Censo Suas em 2018. Os dois grupos etários somados (16 a 17 anos e 18 a 21 anos) estáo sendo chamados na tabela de público potencial para ocupação das repúblicas.

TABELA 24

Situação da ocupação das repúblicas e demanda potencial por moradias para adolescentes e jovens acolhidos em SAFs - Brasil e Grandes Regiões (2018)

\begin{tabular}{|c|c|c|c|c|c|c|}
\hline \multirow{2}{*}{ Especificações } & \multicolumn{5}{|c|}{ Regiões } & \multirow{2}{*}{ Brasil } \\
\hline & Centro-Oeste & Nordeste & Norte & Sudeste & Sul & \\
\hline Acolhidos em SAI de 16 a 17 anos (a) & 295 & 521 & 155 & 2.095 & 1.156 & 4.222 \\
\hline Acolhidos em SAI de 18 a 21 anos (b) & 46 & 82 & 47 & 279 & 84 & 538 \\
\hline Público Potencial (c) (total a+b) & 341 & 603 & 202 & 2.374 & 1.240 & 4.760 \\
\hline Vagas Existentes (d) & 0 & 58 & 0 & 139 & 47 & 244 \\
\hline $\begin{array}{l}\text { Adolescentes e Jovens Vivendo em } \\
\text { Repúblicas (e) }\end{array}$ & 0 & 31 & 0 & 88 & 33 & 152 \\
\hline $\begin{array}{l}\text { Proporção de Ocupacão em relação ao } \\
\text { total de vagas disponíveis (e/d) }\end{array}$ & $0,00 \%$ & $53,45 \%$ & $0,00 \%$ & $63,31 \%$ & $70,21 \%$ & $62,30 \%$ \\
\hline $\begin{array}{l}\text { Déficit annual de vagas distribuídas de } \\
\text { forma adequada (e-c) }\end{array}$ & -341 & -572 & -202 & -2.286 & -1.207 & -4.608 \\
\hline
\end{tabular}

Fonte: Censo Suas 2018. 
No Brasil como um todo, o Censo Suas encontrou 538 jovens de 18 a 21 anos que ainda moravam nas unidades de acolhimentos para crianças e adolescentes em 2018. Desses, cerca da metade (279) vivia em unidades da regiáo Sudeste, em que apenas 63,3\% das vagas em repúblicas estavam ocupadas. Outros 84 jovens de 18 a 21 anos (15,6\%) estavam morando em unidades de acolhimento da regiáo Sul, na qual cerca de um terço das vagas de repúblicas nessa região estava desocupado, posto que a proporção de vagas ocupadas era de 70,2\%. Na regiáo Nordeste, existiam, em 2018, 58 vagas nas repúblicas da região e apenas cerca da metade das vagas estava ocupada $(53,4 \%)$. No entanto, no Nordeste, o Censo Suas encontrou 82 jovens de 18 a 21 anos que ainda moravam nas instituiçóes de crianças e adolescentes, quando já deveriam morar nas repúblicas. Finalmente, nas regiōes Norte e Centro-Oeste, que não ofertavam nenhuma vaga em serviços de repúblicas em 2018, foram encontrados 47 e 46 jovens de 18 a 21 anos, respectivamente, vivendo nos SAIs para crianças e adolescentes. Assim, nessas duas regióes, a ausência de oferta de serviços de repúblicas não se explica pela falta de demanda.

Ademais, para estimar a demanda por vagas em serviços de acolhimento na modalidade repúblicas no curto prazo, é importante considerar a demanda em potencial, constituída pelos adolescentes de 16 a 17 anos acolhidos e que estáo prestes a completar a maioridade. No Brasil como um todo, o Censo Suas encontrou 4.222 pessoas acolhidas nessa faixa etária que deveriam estar sendo preparadas para, em torno de um a dois anos, serem transferidas para as repúblicas. Somando-se os adolescentes de 16 a 17 anos acolhidos com o total de jovens de 18 a 21 anos que ainda viviam nos SAIs em 2018, chega-se a um total de 4.760 adolescentes e jovens, que, estima-se, constituem público potencial demandante dos serviços de repúblicas no país para os dois anos subsequentes à realização do censo, em 2018. ${ }^{60}$ Tendo-se em conta o público potencial, a tabela mostra que a regiáo Sudeste teria um deficit anual de vagas, distribuídas geograficamente de forma adequada, da ordem de (-2.286); na regiấo Sul, o deficit seria de (-1207); e na região Nordeste, $(-572)$ e nas regióes Centro-Oeste e Norte, de (-341) e (-202), respectivamente.

Sem embargo, muito pouco se conhece sobre o destino dos egressos dos serviços de acolhimento. A tabela 25 traz o número de jovens de 16 a 17 anos que deixariam as unidades nos dois anos subsequentes à realização dos respectivos censos e o número de jovens de $18 \mathrm{a}$ 21 anos que ainda viviam nas instituiçóes de crianças e adolescentes, em 2010, 2012, 2014, 2016 e 2018. Estima-se, pelos dados dessa tabela, que 3,9 mil adolescentes e jovens, em média, seriam demandantes de repúblicas durante os próximos dois anos após a publicação de cada censo. Todavia, em 2018, por exemplo, apenas 152 jovens egressos foram encontrados morando nas repúblicas existentes e 538 permaneciam nas unidades, de crianças e adolescentes, totalizando 690 jovens. Ou seja, apenas se conhece o destino de menos de $20 \%$ dos jovens que são desligados dos serviços pela maioridade. Qual teria sido o destino dos demais jovens? Teriam conseguido uma família? Teriam alcançando a autonomia para se autossustentarem, arcando com sua própria sobrevivência? Ou estariam vivendo nas ruas ou enfrentando outros tipos de vulnerabilidades? As respostas a essas perguntas dependem da realização de pesquisas específicas voltadas para conhecer com mais detalhes os serviços de repúblicas, bem como os jovens usuários desses serviços.

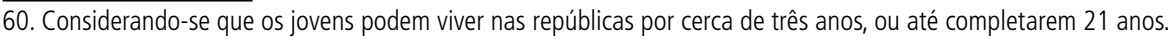


TABELA 25

Adolescentes e jovens acolhidos em SAls - Brasil

\begin{tabular}{lcc}
\hline \multirow{2}{*}{ Ano } & \multicolumn{2}{c}{ Grupos de idade } \\
\cline { 2 - 3 } & 16 a 17 anos & 18 a 21 anos \\
\hline 2010 & 3.733 & 682 \\
2012 & 3.604 & 729 \\
2014 & 3.905 & 520 \\
2016 & 4.036 & 538 \\
2018 & 4.222 & 617 \\
\hline Média & 3.900 & \multicolumn{2}{c}{ (1) } \\
\hline
\end{tabular}

Fontes: Levantamento Nacional, 2010; e Censo Suas 2012, 2014, 2016 e 2018.

Obs.: ${ }^{1}$ Não há informações para esse grupo de idade no Levantamento Nacional de 2010.

O acompanhamento dos jovens egressos dos serviços de acolhimento é fundamental. Afinal, são "filhos do Estado", parafraseando o título do livro de Silva (1997). Para esses jovens, o Sistema de Garantia dos Direitos de Crianças e Adolescentes (SGDCCA) não conseguiu assegurar-lhes os direitos de convivência familiar. Estudos mostram que a transição para a vida fora da instituição é tão complicada que muitos jovens, obrigados a deixar os serviços de acolhimento após a maioridade, ficam em situação de rua e se transformam em público dos Centros de Referência Especializados para População em Situação de Rua (Centros Pop). Uma pesquisa realizada pelo Tribunal de Justiça do Estado de São Paulo (TJSP) em 2018 constatou que alguns dos egressos permaneciam em situação de rua após o desacolhimento e perambulavam próximo às casas-lares onde moraram, pedindo alimentos. Alguns retornavam para suas famílias de origem com rompimento de vínculos de longa data, outros se agrupavam de modo autônomo e ainda há casos em que eram enviados para outros municípios pela instituição de acolhimento para que permanecessem em casas-lares (TJSP, 2018, p. 43).

\subsection{Ações realizadas pelos serviços de república aos acolhidos}

De acordo com as Orientaçóes Técnicas: serviços de acolhimento para crianças e adolescentes (Brasil, 2009) aprovadas pelo Conanda e CNAS em 2009, o objetivo último dos serviços de repúblicas para os jovens desligados pela maioridade dos serviços de acolhimento é constituir-se em espaço de transição e construção da autonomia dos jovens, que devem deixar as repúblicas ao completarem 21 anos. Assim, as açóes que devem ser priorizadas nessa etapa, por parte das equipes técnicas, são aquelas que, fundamentalmente, fortaleçam as competências socioemocionais e cognitivas que ajudem os jovens a serem independentes e protagonistas de suas próprias vidas. Entre as açóes estabelecidas para serem realizadas com os jovens moradores das repúblicas, o referido documento cita: o envolvimento em projetos e serviços nos quais possam desenvolver atividades culturais, artísticas e esportivas que propiciem a vivência de experiências positivas e favorecedoras de sua autoestima; o desenvolvimento de programas de aceleração da aprendizagem, para os casos de grande distorção série-idade; e a frequência a cursos profissionalizantes e programas de inserçáo gradativa no mercado de trabalho - como estágios, programas de adolescente aprendiz etc. 
O gráfico 29 traz as atividades desenvolvidas pelos serviços de acolhimento em repúblicas com os jovens usuários em 2018. É possível dividir as atividades desenvolvidas em cinco grupos diferentes, descritos a seguir.

1) Atividades de apoio socioemocional: atendimento psicossocial individualizado e atendimento psicossocial em grupos.

2) Atividades de apoio elou de aproximaçâo às/das famílias dos acolhidos: atendimento psicossocial das famílias das pessoas acolhidas (orientação familiar); visitas domiciliares da equipe técnica da unidade à família do usuário; reuniōes com grupos de famílias de usuários; e promoçáo do contato e da participaçáo da família na vida do usuário.

3) Atividades sociais e recreativas: atividades recreativas; passeios com usuários; promoção de atividades com participação da comunidade; promoção da participação das pessoas acolhidas em serviços, projetos ou atividades existentes na comunidade; e encaminhamento para retirada de documentos.

4) Atividades de gestão, organização da unidade e acompanhamento técnico do usuário: organização e discussão das rotinas das unidades com os acolhidos; elaboração de relatórios técnicos sobre casos em acompanhamento; e discussão de casos com outros profissionais da rede.

5) Atividades de apoio à ampliação da escolaridade: acompanhamento escolar.

GRÁFICO 29

Serviços de repúblicas, segundo atividades realizadas para os acolhidos - Brasil (2018) (Em \%)

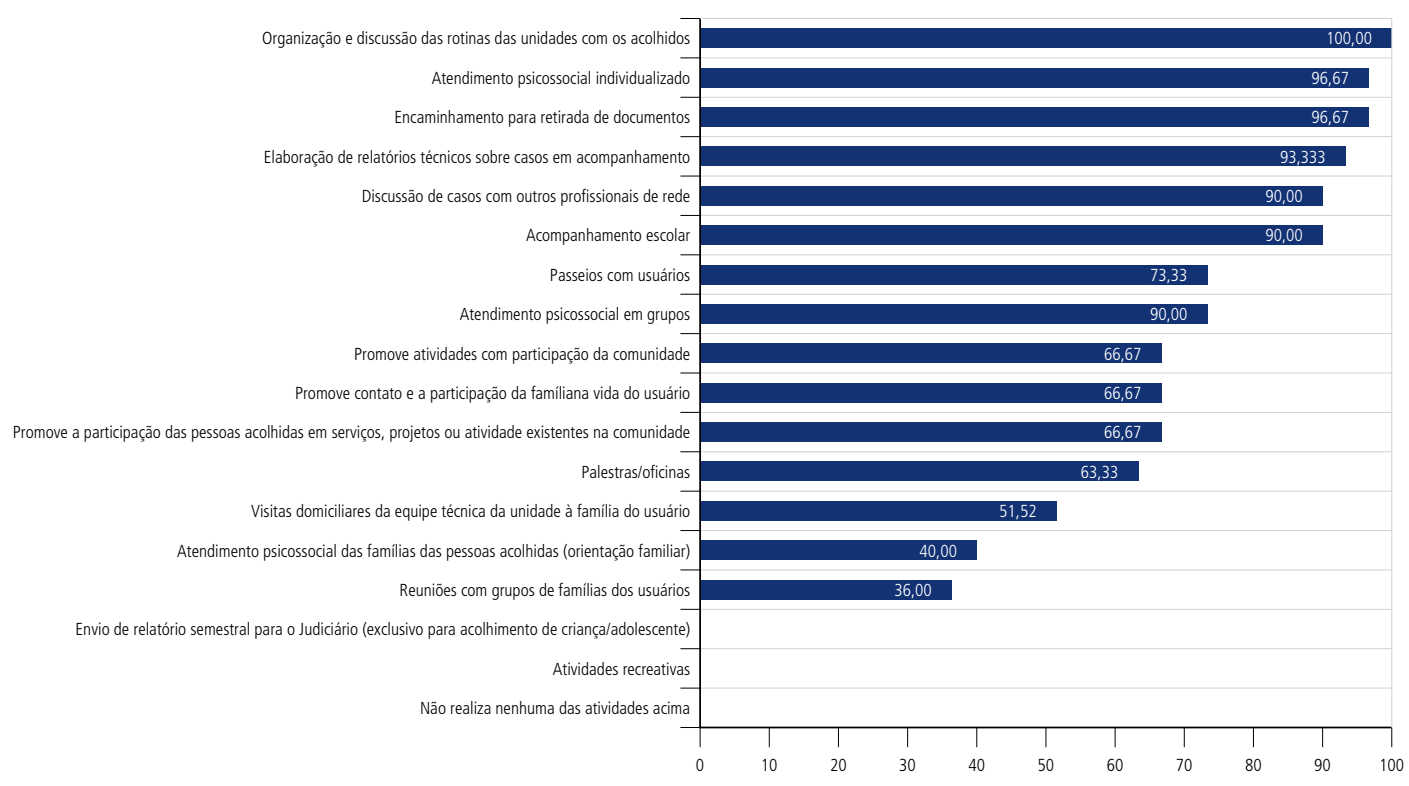

Fonte: Censo Suas 2018.

Conforme apontam os dados do gráfico 29, as atividades mais desenvolvidas pelas unidades são aquelas contidas no grupo de gestão, organização da unidade e acompanhamento técnico do usuário, realizadas por $90 \%$ a $100 \%$ das unidades, seguidas pelas atividades socioemocionais, realizadas por $73,4 \%$ a $96,7 \%$ das unidades, e de apoio às atividades de ampliação da escolaridade, desenvolvidas por $90 \%$ das unidades. As atividades voltadas 
para apoio e/ou aproximação com as famílias dos usuários são também desenvolvidas por uma proporção expressiva dos serviços de repúblicas. Destas, $66,7 \%$ realizam contato e participação da família na vida do usuário; quase $60 \%$ das unidades $(56,7 \%)$ fazem visitas domiciliares da equipe técnica à família do usuário; $40 \%$ prestam atendimento psicossocial às famílias de usuários; e 30\% promovem reunióes com grupos de famílias de usuários.

As atividades sociorrecreativas - como participação dos jovens em projetos desenvolvidos pela comunidade, passeios com os usuários e realização de oficinas e palestras - são também açôes muito presentes na vida dos usuários, realizadas por mais de $70 \%$ das unidades. No entanto, em que pese a grande diversidade de atividades desenvolvidas com os jovens pelas equipes técnicas dos serviços de acolhimento em repúblicas, não foi possível identificar investimentos significativos na qualificação e na capacitação profissional dos usuários. Como os jovens precisam ganhar autonomia financeira até 21 anos, essas ações deveriam também ganhar prioridade por parte das equipes técnicas.

Infelizmente, a partir das estatísticas geradas pelas várias edições do Censos Suas, não verificamos evoluçáo significativa dos serviços de acolhimento em repúblicas a partir da publicação do PNCFC. ${ }^{61} \mathrm{O}$ número residual desses serviços no país segue residual e, mesmo assim, com uma capacidade ociosa de cerca de $40 \%$ das vagas existentes. Essa situação revela flagrante contradição, considerando-se a existência de número bem superior de jovens entre 18 a 21 anos que ainda viviam em serviços de acolhimento de crianças e adolescentes, até mesmo após o alcance da maioridade.

Em relação à adequação da oferta de serviços de repúblicas, a preocupação não se limita aos jovens que, atualmente, estáo na faixa etária de 18 a 21 anos e que ainda moram nos serviços para crianças e adolescentes. Há uma demanda potencial composta pelos jovens de 16 a 17 anos que vivem nos serviços de acolhimento, que se estima ser da ordem de 3,9 mil vagas, em um fluxo de saída de um a dois anos após a realizaçáo de cada censo. Sobre esses jovens, que completam a maioridade nas unidades, pouco se sabe. Conhece-se o destino de apenas $20 \%$ deles - ou seja, daqueles que conseguiram ser transferidos para repúblicas e daqueles que continuaram vivendo nas instituiçóes de crianças e adolescentes; em 2018, foram 152 e 538 jovens, respectivamente.

As atividades realizadas para os jovens por parte dos serviços de repúblicas existentes, por sua vez, são muito diversificadas e englobam desde o apoio na organização da rotina da moradia, até o envolvimento nas açóes da comunidade e o apoio socioemocional para os jovens e suas famílias. Por meio dos dados disponíveis, não foi possível identificar a realização de ações significativas de qualificação para o mercado de trabalho, consideradas fundamentais para a transição para a vida adulta com autonomia.

61. Os dados do Censo Suas anteriores a 2018, relativos aos jovens egressos de serviços de acolhimento (18 a 21 anos), por exemplo, incluíam também a população nessa faixa etária atendida pelas comunidades terapêuticas, implicando grande distorção nos resultados, quando o objetivo da análise era especificamente os serviços de acolhimento em repúblicas. 


\section{A ATUAÇÃO DOS SERVIÇOS DE ACOLHIMENTO À LUZ DO ECA E DO PNCFC}

Como já apontado, o ECA e o PNCFC, no que concerne ao acolhimento institucional, destacam primordialmente, e reiteradamente, a excepcionalidade e a provisoriedade do acolhimento. A aplicação desse princípio, por si só, representa ruptura com o modelo histórico de institucionalização no país, em que os cuidados de crianças e adolescentes em ambiente institucional poderiam estender-se por longos anos (Silva, 1997). Ressalte-se, ainda, que, com base no ECA, o plano afirma a relaçáo entre reordenamento e mudança de paradigma de cuidados. Para colocar a excepcionalidade e a provisoriedade na prática, as atividades ofertadas pelas unidades devem não apenas fornecer proteçáo a crianças e adolescentes com direitos violados, mas também garantir cuidados personalizados e individualizados e até mesmo promover os direitos de cidadania dos acolhidos nessa fase peculiar de desenvolvimento. Busca-se, assim, por meio do reordenamento, evitar a reprodução do modelo de "depósito de crianças", analisado por Silva (1997).

Para fins desse relatório, sintetizamos a relação entre atividades realizadas pelas unidades e a promoçáo do direito à convivência familiar e comunitária por meio de alguns princípios, que orientaram a análise de um grupo de indicadores. $\mathrm{O}$ objetivo é fornecer um panorama da situação atual, bem como, em alguns casos, uma comparação temporal com a situação existente no início desta década ${ }^{62}$ Os dois primeiros princípios referem-se às atividades desenvolvidas pela unidade durante o acolhimento, abordando: i) seu caráter de proteção a direitos e ao desenvolvimento integral das crianças e dos adolescentes; e ii) o grau de abertura institucional para com demais atores do SGDCA. Trata-se, portanto, de analisar a qualidade do serviço de acolhimento em si, durante o período de permanência na unidade. Essas atividades serão analisadas nesta seção.

Os princípios finais referem-se ao elemento fundamental do desligamento, abordando como as unidades atuam para: i) manter os vínculos sociais dos acolhidos; e ii) promover o retorno à vida em contexto familiar. Estas serão analisadas na subseção subsequente, que também traz uma proposta de indicador de desinstitucionalização e sugere um estudo dos fatores institucionais associados a este. Dada a quantidade de informações contidas, não serão realizados, nestas subseçóes, cruzamentos dos indicadores com variáveis territoriais (regiáo e porte do município) e de natureza da unidade (pública ou privada; confessional ou laica). ${ }^{63}$

\subsection{Articulação em rede: incompletude institucional e integração operacional}

Um dos princípios fundamentais do reordenamento é que um SAI não deve ser uma instituição total. ${ }^{64}$ Para tanto, deve-se colocar em prática a ideia da incompletude institucional - isto é, é preciso fomentar a articulação do serviço com outros órgãos do SGDCA, para que os acolhidos, bem como a unidade em si, não fiquem isolados da comunidade onde vivem. Caso contrário, corre-se o risco de colapsar as bases de convívio que colaboram para o sucesso do desligamento

62. A definição de princípios, categorias e indicadores baseia-se em Cores (2014). A seleção dos indicadores utilizados calcou-se na verificação da disponibilidade e da adequabilidade dos dados do Censo Suas, que não foi utilizado na pesquisa citada.

63. Resultados preliminares indicam a relevância de ambas as variáveis para a compreensão dos fenômenos aqui analisados.

64. Instituições totais são "locais de residência e trabalho onde um grande número de indivíduos com situação semelhante, separados da sociedade mais ampla por considerável período de tempo, levam uma vida fechada e formalmente administrada" (Goffman, 2003, p. 11). 
do acolhido e de seu encaminhamento para uma família e, também, para a preservação das possibilidades de convívio familiar e comunitário durante o acolhimento.

Nesta subseção, analisaremos o elemento crucial da porosidade organizacional ao resto do SGDCA - ou seja, a incompletude institucional. Para tanto, abordaremos a relação das unidades de acolhimento com conselhos e unidades da justiça, da educação, da saúde e da assistência social, investigando os tipos e a intensidade das interaçóes institucionais observadas.

No que concerne ao controle externo da unidade, um indicador relevante é o reconhecimento ou não do abrigo por parte do Conselho Municipal de Assistência Social (CMAS) e do Conselho Municipal dos Direitos da Criança e do Adolescente (CMDCA). Esses conselhos - em particular, o de assistência social, dada sua relação mais estreita com a regulamentação do Suas - têm mandato para monitorar as condiçóes de acolhimento. Portanto, a não inscrição em conselhos locais é um indicador importante da ausência de instâncias de controle social capazes de prevenir situaçôes de má prestação de serviços e até mesmo abusos nesses espaços. Como aponta a tabela 26, a inscrição nos conselhos é bastante comum, mas ainda há um bom caminho a ser trilhado.

TABELA 26

Inscrição das unidades de acolhimento nos conselhos de Assistência Social e de Direitos da Criança e do Adolescente

(Em \%)

\begin{tabular}{lccccc}
\hline & 2010 & 2012 & 2014 & 2016 & 2018 \\
\hline No Conselho de Assistência Social (apenas não governamentais) & 92,6 & 95,6 & 96,7 & 96,0 & 96,1 \\
No Conselho de Direitos da Criança e do Adolescente & 87,4 & 86,9 & 88,1 & 88,8 & 89,8 \\
\hline
\end{tabular}

Fontes: Levantamento Nacional, 2010; e Censo Suas 2012, 2014, 2016 e 2018.

Embora exista uma minoria de serviços de acolhimento que sequer contam com inscriçôes nos conselhos municipais relevantes, vale lembrar que a inscrição em conselho, por si só, não significa a existência de relação institucional significativa. Conhecer a realidade dos serviços é importante para a própria possibilidade de priorização das demandas por acolhimento, dado que os conselhos cumprem papel fundamental na destinaçáo de recursos em suas áreas de atuação. Em 2012 e 2014, anos que temos dados disponíveis, cerca de metade das unidades de acolhimento não recebeu visitas destes.

As secretarias municipais de assistência social, o MP e o Judiciário fazem-se presentes com maior frequência. De fato, o acompanhamento pelo órgão gestor municipal é recomendação das próprias Orientaçóes Técnicas do serviço (Brasil, 2009). ${ }^{65}$ Por sua vez, o Conselho Nacional do Ministério Público (CNMP) orienta que seus membros inspecionem pessoalmente as unidades (CNMP, 2013). ${ }^{66}$ No caso do Judiciário, o percentual de visitas é, ainda, bastante baixo. Por sua vez, o envio de relatórios semestrais ao Judiciário por parte

65. Diz a orientação técnica que "Em municípios de médio e grande porte e nas metrópoles - e nos demais quando a demanda justificar o órgão gestor da Assistência Social deverá manter equipe profissional especializada de referência, para supervisão e apoio aos serviços de acolhimento" (Brasil, 2009, p. 44-45).

66. Conforme a seguinte resolução: "O membro do Ministério Público com atribuição em matéria de infância e juventude não infracional deve inspecionar pessoalmente os serviços de acolhimento institucional e programas de acolhimento familiar sob sua responsabilidade" (CNMP, 2011, p. 3). 
das unidades - recomendação do próprio PNCFC - avançou fortemente nos últimos anos, chegando a uma quase universalização da atividade em 2018.

TABELA 27

Órgãos que realizaram visita, inspeção ou supervisão na unidade nos últimos doze meses (2012 e 2014) $(\mathrm{Em} \%)$

\begin{tabular}{lcc}
\hline Órgão & 2012 & 2014 \\
\hline Conselho Tutelar & 68,7 & 68,02 \\
Conselho de Direitos da Criança e do Adolescente & 55,5 & 58,0 \\
Conselho de Assistência Social & 45,0 & 47,1 \\
Secretaria de Assistência Social & 81,2 & 86,2 \\
Judiciário & 76,2 & 80,0 \\
Ministério Público & 84,9 & 89,3 \\
Defensoria Pública & 16,3 & 19,8 \\
\hline
\end{tabular}

Fontes: Censo Suas 2012 e 2014.

Além das relaçóes de inspeção/supervisão, temos as formas por meio das quais as unidades se articulam com outros atores do SGDCA para a realização de suas atividades. Espera-se, no mínimo, que estejam disponíveis dados atualizados de órgãos como o Conselho Tutelar, as unidades e os serviços da assistência social, bem como as unidades educacionais e as de saúde. No segundo nível, o acompanhamento do encaminhamento de acolhidos, de e para esses órgãos, é um indicativo importante de que a unidade organiza seus serviços de forma coordenada com a rede. A tabela 28 sintetiza essas informaçóes.

TABELA 28

Encaminhamento de acolhidos para atendimento em outros órgãos do SGDCA, por parte da unidade (Em \%)

\begin{tabular}{|c|c|c|c|c|c|c|}
\hline \multirow{2}{*}{ Tipo de articulação } & \multirow{2}{*}{ Órgãos do SGDCA } & \multicolumn{5}{|c|}{ Ano } \\
\hline & & 2010 & 2012 & 2014 & 2016 & 2018 \\
\hline \multirow{5}{*}{$\begin{array}{l}\text { Existência de dados de } \\
\text { contato }\end{array}$} & Conselho Tutelar & $94,3^{1}$ & 96,1 & 96,0 & 97,3 & 97,5 \\
\hline & Cras & $78,9^{1}$ & 89,5 & 91,9 & 94,6 & 95,0 \\
\hline & Creas - quando existente & $77,4^{1}$ & 82,7 & 78,2 & 94 & 94,1 \\
\hline & Unidades educacionais & $92,6^{2}$ & 90,0 & 90,1 & - & 92,4 \\
\hline & Serviços de saúde & $90,5^{3}$ & 91,2 & 90,9 & - & 93,5 \\
\hline \multirow{5}{*}{$\begin{array}{l}\text { Acompanha os } \\
\text { encaminhamentos (de/para } \\
\text { a unidade) }\end{array}$} & Conselho Tutelar & - & 57,7 & 54,6 & 57,4 & 55,3 \\
\hline & Cras & - & 53,6 & 55,5 & 60,7 & 63,5 \\
\hline & Creas - quando existente & - & 63,6 & 56,7 & 71,5 & 75,2 \\
\hline & Unidades educacionais & - & 48,7 & 52,2 & - & 61,7 \\
\hline & Serviços de saúde & - & 52,6 & 53,6 & - & 68,0 \\
\hline
\end{tabular}

Fontes: Levantamento Nacional, 2010; e Censo Suas 2012, 2014, 2016 e 2018

Notas: ${ }^{1}$ Os dados de 2010 não incluem o estado de Minas Gerais.

${ }^{2}$ Apenas escolas.

${ }^{3}$ Exceto saúde mental. 
Os dados apontam para um crescimento das relaçóes entre as unidades de acolhimento e os órgãos do SGDCA. Esse crescimento é particularmente forte no caso dos Creas, mas, no que tange ao acompanhamento dos encaminhamentos, verifica-se de forma significativa também para os Cras, os conselhos tutelares, as unidades educacionais e as de saúde.

Em nível mais elevado de articulação, a parceria com outros atores do SGDCA vai além dos encaminhamentos, em direção à atuação conjunta, como uma verdadeira rede de políticas públicas, cuja governança se vale das relaçóes entre os atores, que se percebem como interdependentes. ${ }^{67}$ Nesse caso, espera-se observar a troca de informaçóes, a realização de reunióes, os estudos de casos em conjunto e o desenvolvimento de atividades em parceria. Os dados são apresentados na tabela 29.

TABELA 29

Articulação e cooperação com outros órgãos do SGDCA por parte das unidades de acolhimento (Em \%)

\begin{tabular}{|c|c|c|c|c|c|c|}
\hline \multirow{2}{*}{ Tipo de articulação } & \multirow{2}{*}{ Órgãos do SGDCA } & \multicolumn{5}{|c|}{ Ano } \\
\hline & & 2010 & 2012 & 2014 & 2016 & 2018 \\
\hline \multirow{5}{*}{ Reuniões periódicas } & Conselho tutelar & $43,4^{1}$ & 32,79 & 34,43 & 46,42 & 48,93 \\
\hline & Cras & $41,2^{1}$ & 36,90 & 41,56 & 47,44 & 50,53 \\
\hline & Creas - quando existente & $41,5^{1}$ & 45,42 & 48,51 & 55,91 & 59,64 \\
\hline & Unidades educacionais & $74,4^{2}$ & 49,23 & 49,58 & - & 55,68 \\
\hline & Serviços de saúde & $29,4^{3}$ & 28,34 & 29,48 & - & 43,20 \\
\hline \multirow{5}{*}{ Troca informações } & Conselho tutelar & $92,6^{1}$ & 86,31 & 88,53 & 91,03 & 91,27 \\
\hline & Cras & $70,1^{1}$ & 76,22 & 80,47 & 85,36 & 87,27 \\
\hline & Creas & $51,9^{1}$ & 68,60 & 73,30 & 76,59 & 78,79 \\
\hline & Unidades educacionais & $90,6^{2}$ & 78,72 & 79,64 & - & 84,77 \\
\hline & Serviços de saúde & $80,5^{3}$ & 71,69 & 73,95 & - & 83,94 \\
\hline \multirow{5}{*}{ Estudos de caso em conjunto ${ }^{4}$} & Conselho tutelar & - & 45,51 & 47,97 & 57,17 & 60,16 \\
\hline & Cras & - & 44,44 & 51,05 & 57,33 & 60,44 \\
\hline & Creas & - & 50,80 & 56,86 & 63,30 & 67,46 \\
\hline & Unidades educacionais & - & 33,89 & 33,93 & - & 43,65 \\
\hline & Serviços de saúde & - & 30,72 & 33,14 & - & 45,95 \\
\hline \multirow{5}{*}{ Atividades em parceria ${ }^{4}$} & Conselho tutelar & - & 42,03 & 41,41 & 57,97 & 46,54 \\
\hline & Cras & - & 50,38 & 53,02 & 57,27 & 57,97 \\
\hline & Creas & - & 48,13 & 49,37 & 53,18 & 55,71 \\
\hline & Unidades educacionais & - & 49,91 & 46,64 & - & 50,26 \\
\hline & Serviços de saúde & - & 44,32 & 43,56 & - & 48,76 \\
\hline
\end{tabular}

Fontes: Levantamento Nacional, 2010; e Censo Suas 2012, 2014, 2016 e 2018.

Elaboração dos autores.

Notas: ${ }^{1}$ Os dados de 2010 não incluem o estado de Minas Gerais.

${ }^{2}$ Apenas escolas.

${ }^{3}$ Exceto saúde mental.

${ }^{4}$ Informações não disponíveis para 2010. 
Analisada em seu conjunto, a tabela 29 revela um quadro de crescente articulação entre as unidades de acolhimento e órgáos do SGDCA, apontando para redução do potencial totalizante dessas unidades e para maior concretização do princípio da incompletude institucional ao longo da década. No período analisado, as reuniôes periódicas tornaram-se mais recorrentes; a troca de informaçóes, que já era comum, torna-se regra; os estudos de caso em conjunto também passaram a ocorrer mais; as atividades em parceria idem. Em todos esses casos, observa-se uma abertura cada vez maior das unidades para os conselhos tutelares, os Cras, os Creas, os serviços de educação e de saúde. O Cras é um equipamento com alta cobertura territorial e que, como apresentado na tabela 27, frequentemente se articula com as unidades de SAIs, destacando-se a realização de atividades em parceria. No conjunto, sobressai-se o Creas, quando existente no município, como equipamento público com maior grau de articulaçáo com o acolhimento institucional. Isso é particularmente verdade para as relaçôes mais estruturadas, como os estudos de caso e as reuniôes periódicas.

Infelizmente, os órgãos de justiça não foram objeto de investigação nos anos mais recentes. Ainda assim, a tabela 30 aponta como a Defensoria Pública, o MP e o Judiciário articularam-se com as unidades de acolhimento em 2012 e 2014 . Nota-se, no caso da Defensoria Pública, articulação mais frágil, o que reflete, ao menos em parte, a maior fragilidade institucional das próprias defensorias no território nacional vis-à-vis os outros dois órgãos. Ainda assim, mesmo que consideremos que parte das unidades não tem Defensoria Pública em seu território de atuaçáo - o que explica o baixo percentual de dados de contato -, percebe-se que a articulação com esse órgão está bem aquém dos demais.

O Judiciário, por sua vez, destaca-se. Isso pode ser explicado em parte pela maior capacidade deste em impor decisóes e, também, pela própria natureza jurídica da medida protetiva de acolhimento, que requer decisão - e acompanhamento - judicial. A maior adesão das unidades ao envio de relatórios semestrais também afeta o grau de articulação destas com esse poder. De fato, considerando-se seu papel legalmente definido, ${ }^{68}$ é preocupante que $25 \%$ das unidades náo contem com o apoio do Judiciário no acompanhamento dos encaminhamentos, $15 \%$ náo troquem informaçóes com este, e $6 \%$ sequer tenham dados de contato. Com efeito, por lei, é diretriz da política de atendimento a

integração operacional de órgãos do Judiciário, Ministério Público, Defensoria, Conselho Tutelar e encarregados da execução das políticas sociais básicas e de assistência social, para efeito de agilização do atendimento de crianças e de adolescentes inseridos em programas de acolhimento familiar ou institucional (Brasil, 1990, art. 88, inciso VI).

Assim, náo obstante os dados indiquem alguma melhoria nos últimos anos, e que em muitos casos há um bom nível de articulaçáo, avaliamos que as unidades de acolhimento seguem insuficientemente integradas ao SGDCA, devendo ser envidados maiores esforços para sua integração. Esses esforços poderiam ser potencializados pelo estabelecimento de protocolos mínimos de entendimento entre as instâncias no nível nacional - Conselho Nacional de Justiça (CNJ), Conselho Nacional do Ministério Público, Colégio Nacional

68. Conforme alteração posterior, o § 10 do art. 19 do ECA dispõe que "Toda criança ou adolescente que estiver inserido em programa de acolhimento familiar ou institucional terá sua situação reavaliada, no máximo, a cada 3 (três) meses, devendo a autoridade judiciária competente, com base em relatório elaborado por equipe interprofissional ou multidisciplinar, decidir de forma fundamentada pela possibilidade de reintegração familiar ou pela colocação em família substituta" (Brasil, 1990, § 1, art. 19, grifo nosso). 
de Defensores Públicos Gerais (Condege), MMFDH, SNAS/MC - para definição de responsabilidades e facilitação da atuação coordenada na ponta.

TABELA 30

Articulação com órgãos de justiça (2010, 2012 e 2014)

(Em \%)

\begin{tabular}{|c|c|c|c|c|c|c|c|c|c|}
\hline \multirow{2}{*}{ Tipo de articulação } & \multicolumn{3}{|c|}{ Judiciário } & \multicolumn{3}{|c|}{ Ministério Público } & \multicolumn{3}{|c|}{ Defensoria Pública } \\
\hline & 2010 & 2012 & 2014 & 2010 & 2012 & 2014 & 2010 & 2012 & 2014 \\
\hline Dados de contato & 81,78 & 94,23 & 94,66 & 77,47 & 92,83 & 93,40 & 48,17 & 57,07 & 61,05 \\
\hline Acompanha os encaminhamentos & 73,85 & 77,66 & 77,60 & 58,00 & 65,33 & 67,00 & 24,50 & 21,39 & 23,11 \\
\hline Reuniões periódicas & 50,68 & 55,00 & 59,26 & 37,38 & 42,54 & 47,54 & 10,63 & 9,83 & 11,89 \\
\hline Troca informações & 80,64 & 85,38 & 86,56 & 71,68 & 76,18 & 80,00 & 30,90 & 29,57 & 35,00 \\
\hline Estudos de caso em conjunto & - & 56,05 & 57,93 & - & 35,67 & 38,55 & - & 10,63 & 11,71 \\
\hline Atividades em parceria & - & 46,35 & 46,21 & - & 34,91 & 35,25 & - & 12,41 & 13,14 \\
\hline
\end{tabular}

Fontes: Levantamento Nacional, 2010; e Censo Suas 2012 e 2014

Por fim, um indicador simples - se a unidade encaminha ou não seus acolhidos para a retirada de documentos - permite-nos observar em que medida se fomenta a inclusáo no mínimo denominador comum da cidadania, o reconhecimento formal do cidadão pelo Estado. Esse indicador é particularmente importante, pois instituiçôes totais tendem a ignorar a vida civil de seus internos e pôr obstáculos à sua participação na vida extramuros, inclusive por meio do confisco de documentação. Sua importância é multiplicada quando percebemos que, no caso do acolhimento de crianças e adolescentes, o dirigente da unidade já exercita o poder de guardiáo legal dos acolhidos, ${ }^{69}$ uma vez que estes se encontram afastados do convívio e dos cuidados familiares cotidianos. Outro indicador simples - se os casos são discutidos com outros profissionais - também auxilia a captação da disposição dos profissionais da unidade à colaboraçáo extramuros. Em ambos os casos, a tabela 31 aponta para uma melhoria significativa no período analisado.

TABELA 31

Encaminhamento de acolhidos para a retirada de documentos e discussão de casos com outros profissionais da rede

(Em \%)

\begin{tabular}{lcccc}
\hline \multirow{2}{*}{ Tipo de articulação } & \multicolumn{3}{c}{ Ano } & \\
\cline { 2 - 5 } & 2012 & 2014 & 2016 & 2018 \\
\hline Retirada de documentos & 85,50 & 88,39 & 88,55 & 92,83 \\
Discussão de casos com outros profissionais & 90,42 & 91,15 & 94,03 & 96,48 \\
\hline
\end{tabular}

Fontes: Levantamento Nacional, 2010; e Censo Suas 2012, 2014, 2016 e 2018.

\subsection{Caráter de proteção a direitos e ao desenvolvimento integral das crianças e dos adolescentes}

O caráter socioeducativo e emancipatório do atendimento visa contribuir para a substituição da tendência assistencialista que marca o histórico do acolhimento institucional no Brasil. O princípio realiza-se no cotidiano da unidade por meio de um projeto pedagógico que

69. 0 dirigente de entidade que desenvolve programa de acolhimento institucional é equiparado ao guardião, para todos os efeitos de direito (Brasil, 1990, art. 92, § 1). 
valorize a participação dos acolhidos, tanto como coletivo quanto como individualidades. Individualidades essas que, por sua vez, devem ser consideradas no planejamento.

Começamos a captar essa dimensão por meio das ações voltadas ao engajamento de acolhidos. Na medida que participam das rotinas da unidade, cria-se tanto um espaço de escuta, aprendizado e aprimoramento da própria gestáo, quanto um espaço pedagógico em que os usuários, consideradas as especificidades etárias, têm oportunidades de desenvolvimento da autonomia e aprendem a assumir protagonismo em suas vidas e em suas relaçóes interpessoais. Nota-se que, no extremo oposto, a não participação aliena o acolhido não apenas das regras que deve seguir e das atividades que realiza na unidade, mas também o deixa despreparado para praticar o cuidado de si e para atuar de forma autônoma, prejudicando seu processo de desenvolvimento.

A tabela 32 indica maior participação das crianças e adolescentes entre 2014 e 2018, ainda que não tenhamos informaçóes acerca de como essa participaçáo se dá - o que poderia ser objeto de investigação específica em edição futura da pesquisa.

TABELA 32

SAls que promovem a participação dos acolhidos na organização e na discussão das rotinas (2014, 2016 e 2018)

(Em \%)

\begin{tabular}{ll}
\hline Ano & SAls \\
\hline 2014 & 86,85 \\
2016 & 89,28 \\
2018 & 93,18 \\
\hline
\end{tabular}

Fontes: Censo Suas 2014, 2016 e 2018.

No segundo nível, espera-se que a unidade considere, em seu planejamento, as particularidades de cada acolhido e que, como consequência disso, mantenham-se prontuários individuais e desenvolva-se um PIA. A elaboração do PIA, previsto no art. $101, \$ 4^{\circ}$ do ECA, significa que a unidade projeta, já desde o momento do acolhimento, o trabalho a ser realizado por esta como um conjunto de passos a serem tomados para que o acolhido retorne à vida em ambiente familiar. Esse retorno se dá preferencialmente por meio do retorno à família de origem, ou, alternativamente, considerando cada caso, por intermédio do encaminhamento para adoção. Trata-se, portanto, de indicador não apenas de planejamento, mas também de atenção às individualidades e de compromisso com a saída de crianças e adolescentes dos serviços de acolhimento.

Para além da consideração com as especificidades individuais, espera-se que seja elaborado, no nível da governança da unidade como um todo, um projeto político-pedagógico (PPP). O PPP orienta o funcionamento da unidade, incluindo-se suas regras internas e sua relação com o SGDCA, com a comunidade circundante e com as famílias dos acolhidos (Brasil, 2009, p. 48). 
TABELA 33

SAls que mantêm prontuários individuais e realizam planos individuais de atendimento (Em \%)

\begin{tabular}{lcccc}
\hline & 2012 & 2014 & 2016 & 2018 \\
\hline Manutenção de prontuários individuais & - & - & 95,3 & 98,6 \\
Elaboração de PIA & 91,8 & 96,0 & 97,7 & 97,7 \\
Elaboração de PPP & - & - & - & 81,1 \\
\hline
\end{tabular}

Fontes: Levantamento Nacional, 2010; e Censo Suas 2012, 2014, 2016 e 2018.

TABELA 34

Informações contidas no PIA (2012 e 2014)

(Em \%)

\begin{tabular}{|c|c|c|}
\hline Informações & 2012 & 2014 \\
\hline Dados pessoais do acolhido & - & 99,2 \\
\hline Motivo do acolhimento & 99,1 & 99,4 \\
\hline Situação escolar & 97,5 & 98,0 \\
\hline Saúde do acolhido & - & 97,7 \\
\hline Acolhimentos anteriores & - & 90,3 \\
\hline Encaminhamento para assistência social e outras políticas públicas & 95,0 & 94,4 \\
\hline Comunicação com o sistema de justiça & 92,5 & 91,4 \\
\hline Dados socioeconômicos da família de origem & - & 87,6 \\
\hline Acompanhamento da família de origem & 92,3 & 86,8 \\
\hline Registro de vínculos comunitários & 83,7 & 80,5 \\
\hline Relacionamentos intrafamiliares & - & 88,6 \\
\hline Potencialidades do acolhido & - & 69,1 \\
\hline Participação da família de origem durante o acolhimento & - & 86,0 \\
\hline Inclusão em práticas esportivas, culturais e de lazer & - & 86,5 \\
\hline Plano de ação do acolhido & - & 77,2 \\
\hline Plano de ação com a família do acolhido & - & 68,5 \\
\hline Reavaliação do PIA & - & 75,0 \\
\hline
\end{tabular}

Fontes: Censo Suas 2012 e 2014.

A tabela 34 mostra como os prontuários individuais já eram uma prática comum no início da década, padrão que se manteve ao longo dos anos. Por sua vez, a elaboração de um PIA - exigência legal desde 2009 - e a existência de um PPP - orientaçáo técnica desde 2009 - observaram um grande crescimento, saindo da casa dos $50 \%$ na pesquisa de 2010 para a quase universalização. As pesquisas do Censo Suas de 2012 e 2014 permitem-nos averiguar, entretanto, que uma série de informaçóes relevantes à elaboração de um plano de atendimento segue sendo menos comuns do que o desejado. Chama atenção, em particular, que a convivência familiar e comunitária não seja objeto central dos planos: em 2014, 19,5\% destes não registram vínculos comunitários; $11,4 \%$ não assinalam relacionamentos intrafamiliares; $14 \%$ não planejam a participação da família de origem durante o acolhimento; $13,2 \%$ não preveem o acompanhamento da família de origem; e 31,5\% não envolvem um plano de ação com a família do acolhido.

No que tange às atividades mais gerais a serem desenvolvidas por um SAI, para além do recebimento e do encaminhamento de crianças e adolescente, destacam-se aquelas ligadas a garantia de direitos básicos dos acolhidos, como o acompanhamento educacional e de saúde, 
bem como o direito ao bom acompanhamento dos casos pela administração da unidade e pelo sistema de Justiça, de forma a garantir a prestação de um serviço qualificado. No caso da saúde, entendida em seu sentido amplo, chama atençáo a importância de considerar a saúde psíquica, dado o estágio peculiar de desenvolvimento do usuário e as situaçóes de vida que geram o afastamento do convívio familiar.

TABELA 35

Atividades gerais realizadas pelo SAI

(Em \%)

\begin{tabular}{lcccc}
\hline Atividades gerais & 2012 & 2014 & 2016 & 2018 \\
\hline Acompanhamento escolar & - & 90,72 & 95,38 & 97,28 \\
Atendimento psicossocial individual & 86,90 & 89,57 & 91,92 & 93,77 \\
Atendimento psicossocial em grupo & 59,27 & 63,38 & 66,63 & 73,47 \\
Palestras/oficinas & 52,66 & 51,77 & 54,26 & 62,21 \\
Recreação & 87,50 & 86,85 & - & - \\
Elaboração de relatórios técnicos sobre os casos & 92,11 & 93,76 & 95,97 & 97,11 \\
\hline
\end{tabular}

Fontes: Censo Suas 2012, 2014, 2016 e 2018.

Observa-se que, apesar da flutuação do dado, ainda existem unidades que não realizam o acompanhamento escolar dos acolhidos, o que deve ser objeto de maior investigaçáo - em particular com relaçáo à faixa etária dos acolhidos nessas unidades. De resto, a elaboração de relatórios técnicos e, ainda mais, o atendimento psicossocial têm se tornado prática cada vez mais comum, apontando um avanço.

\section{CONVIVÊNCIA FAMILIAR E COMUNITÁRIA}

Uma vez consideradas as práticas de acolhimento referentes ao funcionamento da unidade em si, à relação com os acolhidos e ao estabelecimento de redes com os atores institucionais do SGDCA na seção anterior, esta seção foca nas práticas e nos resultados obtidos mais diretamente ligados ao objetivo final do serviço - isto é, ao fortalecimento dos vínculos e ao retorno do acolhido à convivência familiar e comunitária - ou, como segunda alternativa, o encaminhamento para adoção. Para tanto, são abordados indicadores referentes à manutenção dos vínculos durante o período de acolhimento institucional, à provisoriedade da permanência na unidade e ao acompanhamento do processo de desligamento.

\subsection{Manutenção dos vínculos familiares e comunitários}

Como apontaram Fonseca e Cardarello (1999), no modelo antigo de "internato dos pobres", unidades de internaçáo de crianças e adolescentes atuavam primordialmente com base na ideia de controlar o risco social de crianças "abandonadas" e/ou "indisciplinadas". As famílias de origem eram objeto de suspeita, e a situação de miserabilidade familiar era considerada como causa para destituição do pátrio poder. Assim, considerava-se preferível encaminhar os internos para famílias adotivas, e, se isso não fosse possível, seria melhor manter a criança e o adolescente internados. Esse modelo, embora não encontre mais guarida na legislação, segue guiando representaçóes e práticas de gestores e trabalhadores da área, afetando a forma como se presta o SAI. 
Para captar em que medida as unidades de acolhimento atualmente têm buscado superar essas concepçóes, o Censo Suas tem incluído regularmente uma série de questóes referentes à promoção da convivência familiar e comunitária. A manutenção de vínculos fraternais depende, amiúde, do acolhimento institucional permitir que grupos de irmãos fiquem juntos. Os dados permitem-nos averiguar três dimensóes dessa questáo. Primeiro, há a questão de se a unidade acolhe grupos de irmáos quando há demanda. Segundo, para aquelas que o fazem, resta saber se a separação de gênero, que é regra em algumas unidades, impede que certos grupos de irmáos permaneçam juntos.

Para além do acolhimento conjunto, a convivência familiar depende da manutenção do contato por meio de visitas. Diferentes serviços operam distintos regimes de visitação por parte dos familiares, desde a proibição estrita até a permissão de visitas diárias. Para que as visitas aconteçam, a localização do serviço deve ser acessível a todos, preferencialmente localizada em áreas urbanas não isoladas e com transporte público próximo. Além disso, concorrem para o estreitamento dos laços a promoção do contato e da participação da família na vida do acolhido, a realização de reuniōes com grupos de famílias, a realização de visitas à família e a orientação familiar.

No que se refere à convivência comunitária, a simples realização de passeios já é um indicativo básico do estabelecimento de relaçôes com o mundo externo. No segundo nível, temos a participação dos acolhidos em atividades da comunidade, bem como a participação da comunidade em atividades realizadas no SAI. Por fim, há a questão da manutenção dos vínculos náo familiares dos acolhidos, e para tanto devemos observar se - e com qual frequência - é permitida a visita de pessoas que não são da família.

TABELA 36

Manutenção de vínculos fraternais nos SAls (Em \%)

\begin{tabular}{|c|c|c|c|c|c|}
\hline Manutenção de vínculos fraternais & 2010 & 2012 & 2014 & 2016 & 2018 \\
\hline Unidade possui critérios de sexo para admissão de acolhidos & 22,2 & 20,4 & 16,6 & 14,2 & 10,4 \\
\hline Sexo masculino apenas & 12,5 & 11,3 & 9,3 & 8,1 & 6,1 \\
\hline Sexo feminino apenas & 9,7 & 9,1 & 7,2 & 6,1 & 4,3 \\
\hline Unidade afirma acolher grupo de usuários com vínculo de parentesco & 99,1 & 91,9 & 93,6 & 94,9 & 95,6 \\
\hline Sempre que há demanda & 84,6 & 81,4 & 87,0 & 89,3 & 91,1 \\
\hline Algumas vezes & 14,4 & 10,6 & 6,6 & 5,6 & 4,6 \\
\hline
\end{tabular}

Fontes: Levantamento Nacional, 2010; e Censo Suas 2012, 2014, 2016 e 2018.

A última década apresentou claro avanço na manutenção de vínculos fraternais, com a redução expressiva das unidades com critérios de sexo para admissáo de acolhidos. Além disso, em que pesem os dados de 2010 apresentarem resultados um pouco díspares, cresceu sistematicamente, a partir de 2012, a proporção de serviços que buscam acolher grupos de usuários com parentesco sempre que há demanda, e reduziu-se sistematicamente a proporçáo daqueles que não fazem o acolhimento nesses casos. Mas note-se, a esse respeito, que a potencial complexidade e gravidade de algumas situaçóes podem exigir o atendimento especializado, a exemplo da adoção de faixas etárias para, nos termos das Orientaçôes Técnicas (Brasil, 2009), possibilitar uma atenção diferenciada a vulnerabilidades específicas - e.g. adolescentes em situação de rua, em conflito com a lei em 
cumprimento de medidas socioeducativas em meio aberto, com uso abusivo de drogas, adolescentes grávidas ou com filhos pequenos, entre outras situaçóes. Nesse sentido, alguns casos podem levar à oferta de serviços para essa faixa etária como estratégia de proteção e melhoria do atendimento, com maior atenção a suas especificidades. Metodologias mais especificamente voltadas às demandas desse público podem ser adotadas. Trata-se de questáo candente e que merece um estudo mais aprofundado. ${ }^{70}$ Todavia, nos termos das Orientaçóes Técnicas, as especializaçóes justificáveis devem sempre se somar à oferta de serviço(s) que, em âmbito local, assegurem a manutenção conjunta de grupos de irmãos.

TABELA 37

Proporção de SAls por tipo de frequência de visitações

(Em \%)

\begin{tabular}{|c|c|c|c|c|c|}
\hline Frequência das visitas & 2010 & 2012 & 2014 & 2016 & 2018 \\
\hline \multicolumn{6}{|c|}{ Famílias } \\
\hline Diariamente & 28,8 & 23,5 & 22,1 & 22,4 & 22,3 \\
\hline 3 a 6 dias por semana & \multirow{2}{*}{55,1} & 8,2 & 9,4 & 10,9 & 13,9 \\
\hline 1 a 2 dias por semana & & 54,2 & 55,2 & 54,2 & 52,8 \\
\hline quinzenal & 5,1 & 6,8 & 7,1 & 6,8 & 6,8 \\
\hline mensal & 2,5 & 2,1 & 2,8 & 2,3 & 1,1 \\
\hline apenas em datas específicas & - & 2,4 & 1,1 & 1,0 & 1,2 \\
\hline não é permitido & 7,9 & 2,8 & 2,3 & 2,4 & 1,8 \\
\hline outras datas & 0,3 & - & - & - & - \\
\hline Sem informação & 0,2 & - & - & - & - \\
\hline \multicolumn{6}{|c|}{ Outras pessoas } \\
\hline Diariamente & - & - & - & - & 14,7 \\
\hline 3 a 6 dias por semana & - & - & - & - & 7,0 \\
\hline 1 a 2 dias por semana & - & - & - & - & 35,0 \\
\hline quinzenal & - & - & - & - & 6,3 \\
\hline mensal & - & - & - & - & 3,3 \\
\hline apenas em datas específicas & - & - & - & - & 21,3 \\
\hline não é permitido & - & - & - & - & 12,4 \\
\hline Sem informação & - & - & - & - & 0,1 \\
\hline
\end{tabular}

Fontes: Levantamento Nacional, 2010; e Censo Suas 2012, 2014, 2016 e 2018.

Com relação à frequência de visitações, chama atenção a redução na proporção de SAIs que não permitem visitas (de 6,9\%, em 2010, para 1,8\%, em 2018) e o aumento dos que as possibilitam ao menos uma vez por semana (de 83,9\%, em 2010, para 89\%, em 2018). Ainda assim, mantém-se uma situaçáo em que um de cada dez SAIs não permite visitas semanais de familiares aos acolhidos, e, daqueles que as possibilitam, em sua maioria o número de visitas não ultrapassa duas vezes por semana. Entende-se que seria relevante incluir questóes sobre os motivos dessa restrição em versóes futuras da pesquisa, e que se incluísse também os motivos para a restrição de contato com outras pessoas, uma vez que $12,4 \%$ dos serviços não permitem visitas de pessoas de fora da família e $21,4 \%$ apenas as possibilitam em datas específicas.

70. A respeito da especialização do atendimento em situações que exijam metodologias diferenciadas para atendimento mais qualificado aos acolhidos, sugere-se a leitura do material de Torquato et al. (2020). 
TABELA 38

Facilidade de acesso ao SAls: distância, transporte público e indicadores de acessibilidade predial (Em \%)

\begin{tabular}{|c|c|c|c|c|}
\hline Facilidades de acesso & $2012^{(2)}$ & 2014 & 2016 & 2018 \\
\hline Unidade em área rural & 4,4 & 3,5 & - & 2,7 \\
\hline Sem transporte público nas proximidades (mais de 30 minutos de caminhada) & 12,9 & 12,8 & 15,2 & 15,5 \\
\hline Com transporte público a média distância ( 1 a 2 km/ 15 a 30 minutos de caminhada) & 2,7 & 3,2 & 2,9 & 3,2 \\
\hline Rampa e rota acessível até a unidade - norma da ABNT ${ }^{1}$ & \multirow{2}{*}{37,0} & \multirow{2}{*}{39,7} & 21,1 & 25,5 \\
\hline Rampa e rota acessível até a unidade - em desacordo com ABNT & & & 32,3 & 31,7 \\
\hline Rota acessível aos espaços coletivos e dormitórios - norma ABNT & \multirow{2}{*}{61,2} & \multirow{2}{*}{60,9} & 27,5 & 30,4 \\
\hline Rota acessivel aos espaços coletivos e dormitórios - em desacordo com ABNT & & & 39,7 & 38,8 \\
\hline Rota acessível ao banheiro - norma ABNT & \multirow{2}{*}{63,4} & \multirow{2}{*}{62,2} & 28,5 & 31,9 \\
\hline Rota acessível ao banheiro - em desacordo com ABNT & & & 39,8 & 38,4 \\
\hline Banheiro adaptado - norma ABNT & \multirow{2}{*}{15,8} & \multirow{2}{*}{21,7} & 19,6 & 23,0 \\
\hline Banheiro adaptado - em desacordo com ABNT & & & 14,7 & 15,9 \\
\hline
\end{tabular}

Fontes: Censo Suas 2012, 2014, 2016 e 2018.

Nota: ${ }^{1}$ ABNT - Associação Brasileira de Normas Técnicas.

${ }^{2} \mathrm{O}$ Censo Suas de 2012 não coletou informações sobre a adequação à ABNT das estruturas de favorecem a acessibilidade.

Com relaçáo ao acesso às unidades dos SAIs, observa-se uma redução das localizadas em áreas rurais, mas, ao mesmo tempo, um crescimento no percentual daquelas sem transporte público nas proximidades, o que obviamente limita a possibilidade de convivência familiar e comunitária. Quanto à acessibilidade para pessoas com deficiência e mobilidade reduzida, a situação melhorou ao longo dos anos. A existência de rampas e rotas acessíveis até o serviço saiu de 37\%, em 2010, para 67,2\%, em 2018; os banheiros adaptados existiam em 15,8\% das unidades em 2012 e em 38,9\%, em 2018. Ademais, a comparação dos dados de 2016 e 2018 sugerem ampliaçáo da acessibilidade com qualidade, segundo as normas da ABNT. Ainda assim, cabe notar que parcela muito significativa dos SAIs segue tendo limitaçóes importantes nesse quesito. É importante frisar, entretanto, que muitos destes funcionam em edificações que são alugadas. Preferencialmente, deseja-se que estas sejam casas nas próprias comunidades, com vários quartos e com, no máximo, quatro usuários por quarto. Infelizmente, casas grandes e que permitam mudanças estruturais são difíceis de encontrar. Uma orientação possível nesses casos é o uso dos recursos do cofinanciamento federal para reformas e adaptaçóes de acessibilidade voltadas ao atendimento das necessidades das pessoas com deficiência. ${ }^{72} \mathrm{~A}$ tabela 39 revela um progressivo aprimoramento na promoçăo da convivência comunitárias dos acolhidos.

Os passeios tornaram-se mais comuns, e, principalmente, a promoção da participação em atividades com a comunidade observaram um salto importante. Esse crescimento foi contínuo ao longo dos anos, concomitante à melhoria na promoção da convivência familiar, retratada na tabela 34. Além da maior frequência na promoção de atividades, tais como a orientação familiar e a reunião com grupo de famílias, destaca-se como a visitação da equipe técnica à família do acolhido se tornou uma atividade realizada por praticamente todos os serviços.

71. 0 dado é um somatório das opções de resposta correspondente em 2018.

72. Agradecemos a Juliana Pereira e Cinthia dos Santos por nos chamarem a atenção a esse aspecto. 
TABELA 39

Atividades de promoção da convivência comunitária

(Em \%)

\begin{tabular}{|c|c|c|c|c|}
\hline Atividades de promoção da convivência comunitária & 2012 & 2014 & 2016 & 2018 \\
\hline Passeios com usuários & 90,7 & 91,3 & 92,2 & 95,3 \\
\hline Promove atividades com participação da comunidade & 73,9 & 74,5 & 78,9 & 81,9 \\
\hline Promove participação dos acolhidos em serviços, projetos e atividades na comunidade & 87,1 & 87 & 89,3 & 93,6 \\
\hline
\end{tabular}

Fontes: Levantamento Nacional, 2010; e Censo Suas 2012, 2014, 2016 e 2018.

TABELA 40

Atividades de promoção da convivência familiar

(Em \%)

\begin{tabular}{|c|c|c|c|c|}
\hline Atividades de promoção de convivência familiar & 2012 & 2014 & 2016 & 2018 \\
\hline Visitação da equipe técnica à família do acolhido & 86,3 & 89,7 & 94 & 95,4 \\
\hline Reunião com grupos de famílias & 43,1 & 46,5 & 50,9 & 61,1 \\
\hline Atendimento psicossocial/orientação familiar & 73 & 76,9 & 83,9 & 88,4 \\
\hline Promoção do contato e da participação da família na vida do acolhido & - & - & 83,3 & 92,2 \\
\hline
\end{tabular}

Fontes: Censo Suas 2012, 2014, 2016 e 2018.

\subsection{Provisoriedade da permanência e acompanhamento do desligamento}

Para analisarmos a provisoriedade da permanência e o acompanhamento do desligamento, o Censo Suas fornece-nos, ao longo dos anos, uma série de indicadores. Chama atenção, no que concerne à exigência legal de que o acolhimento institucional seja provisório e não se prolongue para além do necessário, que ainda se observe a continuidade de práticas de acolhimento institucional que duram, por vezes, mais de seis anos. A tabela 41 apresenta a proporção de acolhidos por tempo de permanência para os anos selecionados.

TABELA 41

Acolhidos por tempo de permanência

(Em \%)

\begin{tabular}{lrrrrr}
\hline Tempo de permanência & 2010 & 2012 & 2014 & 2016 & 2018 \\
\hline Menos de 1 mês & 7,8 & 8,0 & 8,7 & 7,9 & 9,2 \\
1 a 3 meses & 15,7 & 14,7 & 14,8 & 16,4 & 17,5 \\
4 a 6 meses & 11,9 & 14,3 & 13,4 & 14,2 & 14,9 \\
7 a 12 meses & 16,5 & 18,1 & 17,5 & 18,4 & 18,1 \\
13 a 24 meses & 17,7 & 17,8 & 17,2 & 18,7 & 17,9 \\
25 a 48 meses & 14,8 & 13,1 & 12,9 & 12,1 & 11,6 \\
49 a 72 meses & 6,6 & 5,7 & 6,0 & 5,2 & 4,4 \\
Mais de 72 meses & 9,0 & 8,2 & 9,4 & 7,0 & 6,5 \\
Total & $\mathbf{1 0 0 , 0}$ & $\mathbf{1 0 0 , 0}$ & $\mathbf{1 0 0 , 0}$ & $\mathbf{1 0 0 , 0}$ & $\mathbf{1 0 0 , 0}$ \\
\hline
\end{tabular}

Fontes: Levantamento Nacional, 2010; e Censo Suas 2012, 2014, 2016 e 2018. 
Os dados revelam dinâmica de redução contínua, mas modesta, no tempo de acolhimento institucional. Observam-se, ao longo dos anos, crescimento contínuo da proporção de acolhidos com tempo de permanência inferior a um ano e queda progressiva daqueles acolhidos por mais de dois anos. Note-se, a esse respeito, que o ECA preconizava, entre 2009 e 2017, um prazo máximo de dois anos de acolhimento, mas, desde 2017, o prazo reduziu-se a dezoito meses: ${ }^{73}$ infelizmente, não temos dados desagregados por dezoito meses, o que, em vista da mudança legislativa, deveria ser incorporado ao Censo Suas. De qualquer sorte, a tendência ao longo da década é salutar. Mas cabe ressaltar o quanto ainda resta a avançar nesse quesito, uma vez que permanências muito longas continuam sendo práticas corriqueiras. O gráfico 30 aponta essa reduçâo modesta na proporção de acolhidos por longo tempo, indicando que, enquanto em 2010 o percentual dos institucionalizados por mais de 24 meses era de 30,6\%, em 2018 esse número cai para $22,5 \%$.

GRÁFICO 30

Proporção de acolhidos com mais de 24 meses de acolhimento (Em \%)

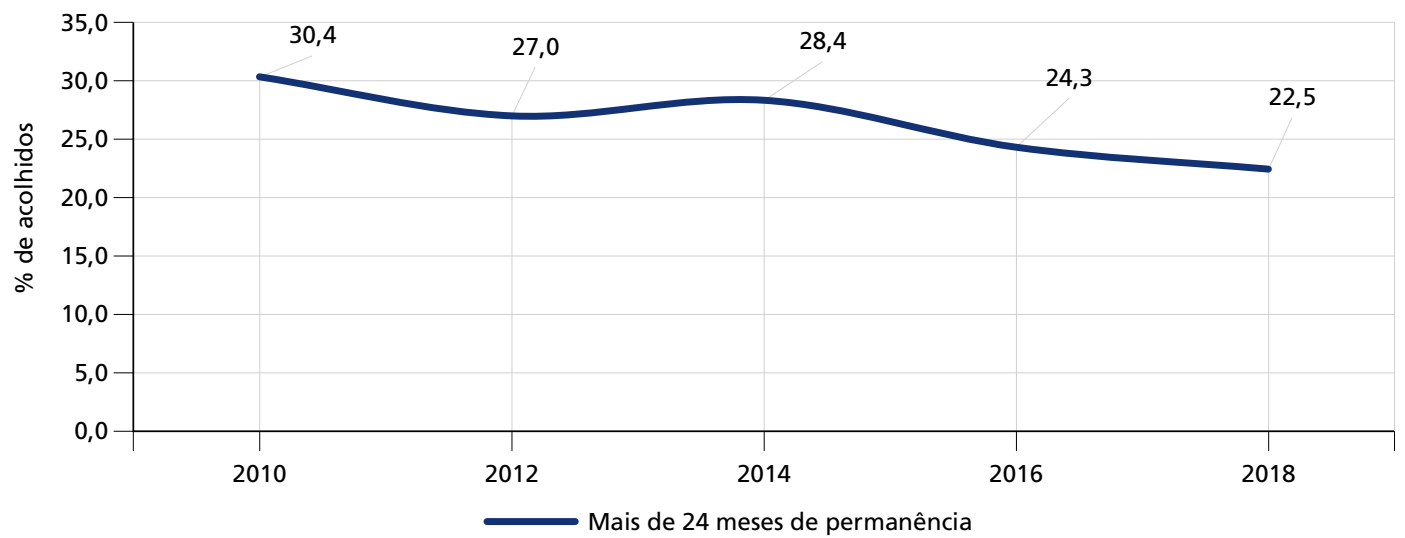

Fontes: Levantamento Nacional, 2010; e Censo Suas 2012, 2014, 2016 e 2018

Dada a centralidade desse indicador (tempo de permanência da criança no serviço) para o monitoramento e o aprimoramento do serviço de acolhimento institucional, haja vista o princípio da provisoriedade, a tabela 42 apresenta uma análise preliminar de características dos SAIs com tempo médio de acolhimento mais alto. Para tanto, calculamos uma estimativa ${ }^{74}$ para cada faixa de tempo de permanência, apresentadas na tabela 41. Mesmo considerando que a duraçáo do acolhimento é uma estimativa e que os fatores correlacionados precisam ser analisados em contexto e não interpretados como relaçóes causais simples, os resultados apontam para alguns caminhos possíveis no campo da regulação das unidades.

73. "A permanência da criança e do adolescente em programa de acolhimento institucional não se prolongará por mais de 18 (dezoito meses), salvo comprovada necessidade que atenda ao seu superior interesse, devidamente fundamentada pela autoridade judiciária" (Brasil, 1990. art. 19, § 2).

74. Em que 1 mês é entendido como 0,5 meses, mais de 72 meses, como 90 meses e demais faixas são calculadas a partir do ponto médio entre limite inferior e superior (e.g., entre 1 e 3 meses = 2 meses). Notamos que, particularmente no caso da permanência maior que seis anos, há certa arbitrariedade na definição do valor. Isso pode ser aprimorado com uso dos microdados da pesquisa Levantamento Nacional dos Abrigos para Crianças e Adolescentes da Rede SAC (Silva, 2004), que trazem a distribuição de acolhidos por tempo, mas, no momento, considera-se mais proveitoso avançar no cálculo de um indicador de desinstitucionalização - a ser apresentado na próxima subseção. 
TABELA 42

Características dos serviços com alto tempo médio de acolhimento (2018)

\begin{tabular}{lc}
\hline Características & Significância (p) \\
\hline Não realiza visitas domiciliares à família do acolhido & .000 \\
Não realiza reuniões com grupos de famílias & .001 \\
Não realiza atendimento psicossocial individualizado & .000 \\
Não realiza atendimento psicossocial/orientação das famílias & .004 \\
Não elabora relatórios técnicos dos casos & .039 \\
Não faz acompanhamento escolar & .001 \\
Não organiza e discute as rotinas da unidade com os acolhidos & .003 \\
Ninguém realiza acompanhamento do acolhido após o desligamento & .008 \\
Não sabe se alguém realiza acompanhamento do acolhido após o desligamento & .001 \\
\hline
\end{tabular}

Fonte: Censo Suas, 2018.

O teste de hipóteses indicou correlação entre tempo de acolhimento e a realização de certas atividades. Na tabela 42, quanto mais próxima de 0.000 for a significância (p), maior a correlação estatística entre a não realização de determinadas atividades e alto tempo de acolhimento. Destacam-se a alta correlação entre a longa permanência e a não realização de visitas domiciliares às famílias dos acolhidos, reuniōes com grupos de famílias, atendimento psicossocial individualizado e acompanhamento escolar. Por contraste, serviços que oferecem esses tipos de atendimento e atividades estáo mais correlacionados a acolhimentos com tempo de permanência menor.

Chama atenção também a relação entre a participação dos acolhidos na discussão das rotinas da unidade e a duração do acolhimento. Assim como entre esse indicador e as atividades de acompanhamento dos egressos após seu desligamento do serviço. Unidades que não sabem sequer se alguém faz esse acompanhamento têm tempo de permanência maior, como aponta o teste de hipóteses. Esses dados sugerem que o investimento em ações de apoio aos acolhidos e às suas famílias por parte das equipes técnicas das unidades contribui de forma significativa para a redução do tempo médio de acolhimento de crianças e adolescentes: ou porque foram reintegrados às suas famílias de origem ou porque restabeleceram seu direito à convivência familiar por meio da adoção.

TABELA 43

Tempo médio de acompanhamento de acolhidos após o desligamento (2014, 2016 e 2018) (Em \%)

\begin{tabular}{lccc}
\hline Tempo médio & 2014 & 2016 & 2018 \\
\hline Menos de 3 meses & 6,5 & 5,2 & 3,5 \\
De 3 a 5 meses & 10,6 & 8,8 & 8,5 \\
6 meses & 64,9 & 68,2 & 73,7 \\
De 7 a 12 meses & 9,3 & 10,1 & 8,9 \\
Mais de 1 ano & 8,6 & 7,7 & 5,3 \\
\hline
\end{tabular}

Fontes: Censo Suas 2014, 2016 e 2018.

Com relação à questão quem?, observamos que, por vezes, é o próprio SAI que faz o acompanhamento; por vezes, é algum centro socioassistencial, como o Cras e o Creas; por vezes, é outra instituição. E, por vezes, ninguém o faz. A tabela 42 aponta tendência de crescente participação do próprio serviço e dos Creas nesse acompanhamento, o que é desejável 
e converge com as Orientaçóes Técnicas (Brasil, 2009). O serviço de acolhimento, por ter contato mais estreito com as crianças e/ou adolescentes que ficaram sob sua guarda - e, idealmente, com suas famílias -, poderia contribuir com os Creas no acompanhamento após o desligamento, mantendo-se sempre como referência na vida dos meninos e meninas que lá passaram grande parte de suas vidas. No entanto, a responsabilidade institucional de acompanhamento dos egressos poderia ser atribuída aos Creas que, no Suas, já têm a atribuição de acompanhar e orientar famílias e indivíduos na direção do fortalecimento de vínculos familiares, comunitários e sociais.

Quanto ao Creas, chamam atenção dois fatores. O crescimento de sua participação no acompanhamento, de 51,4\%, em 2012, para 63,3\%, em 2018, torna-se ainda mais significativo quando consideramos que nem todos os municípios têm Creas. Se admitirmos apenas os municípios com Creas, o percentual de acompanhamento era de 60,9\%, em 2012, e 72,8\%, em 2018. Por seu turno, esse crescimento pode estar relacionado com a própria expansão do número dessas unidades nos territórios ao longo dos anos. Além disso, tal crescimento se faz concomitante à estabilidade dos indicadores de acompanhamento por parte dos Cras, indicando uma crescente preferência por esse equipamento de proteção social especial no acompanhamento dos desligamentos. Tal tendência se faz, por sua vez, de forma coordenada com a maior articulação com o Creas de forma geral, como apontado nas tabelas 43 e 44 .

TABELA 44

Instituição responsável pelo acompanhamento de acolhidos após o desligamento

(Em \%)

\begin{tabular}{lrrrrr}
\hline Acompanhamento do acolhido & $2010^{1}$ & 2012 & 2014 & 2016 & 2018 \\
\hline A própria unidade & 23,3 & 57,2 & 61,5 & 64,7 & 69,2 \\
Cras & 14,4 & 49,0 & 50,2 & 50,1 & 51,1 \\
Creas & - & 51,4 & 56,5 & 59,6 & 63,3 \\
Outra & - & 23,4 & 17,6 & 15,3 & 15,3 \\
Ninguém & 42,6 & 4,0 & 2,6 & 1,7 & 1,4 \\
Não sabe informar & 19,7 & 3,5 & 2,1 & 0,9 & 0,9 \\
\hline
\end{tabular}

Fontes: Levantamento Nacional, 2010; e Censo Suas 2012, 2014, 2016 e 2018.

Nota: ${ }^{1}$ Apenas para saída por maioridade.

\subsection{Proposta de indicador de avaliação do PNCFC: taxa de desinstitucionalização - ou desligamento}

O Censo Suas de 2016 e 2018 incluiu, além de uma questão relativa ao número de acolhidos, duas questóes relativas ao fluxo de saída do SAI ao longo de doze meses. Seja essa saída motivada pelo retorno à família de origem ou pelo encaminhamento à uma família substituta, temos dados suficientes para calcular uma taxa de desinstitucionalizaçáo ou desligamento - os termos são intercambiáveis - das crianças e dos adolescentes acolhidos. Uma vez que a excepcionalidade e a provisoriedade do acolhimento institucional é a principal diretriz do PNCFC para o público em análise, o desligamento é um bom indicador de eficácia do acolhimento institucional à luz do PNCFC. 
Em suma, quanto mais crianças e adolescentes são desligados ao longo de determinado período, considerando-se o número total de crianças e adolescentes acolhidos, mais próximos estamos do objetivo final da medida protetiva de acolhimento e mais adequados estão os serviços que acolhem. Isto é, mais próximos estamos, se não do princípio da excepcionalidade, ao menos do princípio da provisoriedade. Por certo, esses desligamentos precisam ser preparados, conduzidos com cuidado. Desligamentos que não são bem conduzidos e levam ao retorno ao acolhimento são situaçóes dramáticas para todos os envolvidos, principalmente para as crianças e os adolescentes.

Assim, considera-se que a proposta aqui apresentada poderá ser aprimorada com a obtenção de dados mais apropriados, e recomenda-se à SNAS e ao CNJ que busquem, em seus processos de aprimoramento contínuo das informaçóes produzidas, cotejar a possibilidade de produzir esses dados. O ideal seria obter o número total de acolhidos ao longo do período de doze meses, e não o número de acolhidos à época da pesquisa; informação essa que poderia ser coletada, eventualmente, via Censo Suas. Como não há disponibilidade dessas informaçóes até o momento, devemos aceitar que o denominador de nosso indicador é uma proxy do total de acolhidos ao longo do período. Isso significa aceitar certo nível de erro no dado de base e, portanto, certo nível de "ruído" estatístico em qualquer análise realizada por meio desse indicador. Esse ruído é relativamente alto no nível individual - i.e., para cada SAI -, mas relativamente baixo do ponto de vista agregado, uma vez que temos mais de 2.400 unidades no Brasil. Logo, devemos evitar análises individualizadas, das "árvores", e nos atermos às características da "floresta".

Adotar um indicador simples de eficácia não significa, faz-se necessário salientar, que apenas um índice ou taxa seja capaz de captar a complexidade do fenômeno. Mas significa que, ao menos em alguns casos, há boas razóes para argumentar pela adequabilidade do indicador em captar uma parte desse fenômeno que consideramos de especial relevância. Julgamos ser esse o caso aqui. $\mathrm{O}$ cálculo do indicador por unidade é simples. Sendo $D$ a taxa de desligamento; $F$, o número de crianças e adolescentes do serviço que retornaram às suas famílias de origem nos últimos doze meses; $S$, o número de crianças/adolescentes do SAI que foram encaminhadas à adoção ou a famílias substitutas nos últimos doze meses; e $A$, o número de crianças/adolescentes acolhidos no serviço no momento, temos:

$$
D_{i}=\frac{F_{i}+S_{i}}{A_{i}}
$$

Dado que nem todos os serviços informaram os dados que utilizamos para o cálculo do indicador, ou informaram não ter qualquer acolhido no momento da pesquisa, tem-se que uma parcela destes foi excluída (missing). Além disso, como $A$ não é um indicador de fluxo como $F$ e $S$, temos a possibilidade de resultados muito díspares caso tenhamos um SAI com, por exemplo, apenas uma criança acolhida no momento, mas que desligou trinta crianças ao longo do ano, o que resultaria em taxa de $3.000 \%$. Sendo assim, excluímos os outliers com base na abrangência interquartis. ${ }^{75}$ Para o cálculo do indicador geral, por sua vez, devemos dar o mesmo valor para cada criança e adolescente acolhido. Em suma, temos de dar a cada SAI o peso correspondente ao seu número de acolhidos. O resultado é apresentado na tabela 45.

75. Ver Hoaglin et al. (1986). Foram utilizados os dados preliminares do Censo Suas 2018, uma vez que os novos dados apresentaram inconsistências. 
TABELA 45

Taxa de desinstitucionalização e estatísticas descritivas (2018) ${ }^{1}$

\begin{tabular}{llc}
\hline & Válidos (acolhidos) & 27.972 \\
& Missing (acolhidos excluídos da análise) & 2.850 \\
& Válidos (unidades) & 2.302 \\
Média & Missing (unidades excluídas) & 545 \\
Mediana & & 0,60 \\
Moda & & 0,50 \\
Desvio padrão & & 0,00 \\
Mínimo & & 0,45 \\
Máximo & & 0,00 \\
& $10 \%$ & 1,94 \\
& $20 \%$ & 0,07 \\
& $25 \%$ & 0,20 \\
& $30 \%$ & 0,25 \\
& $40 \%$ & 0,30 \\
& $50 \%$ & 0,40 \\
& $60 \%$ & 0,50 \\
& $70 \%$ & 0,65 \\
& $75 \%$ & 0,80 \\
& $80 \%$ & 0,90 \\
$90 \%$ & 1,00 \\
& $95 \%$ & 1,25 \\
& $99 \%$ & 1,50 \\
& & 1,81 \\
\hline
\end{tabular}

Fontes: Censo Suas 2016 e 2018

Nota: ${ }^{1}$ Foram utilizados dados preliminares do Censo Suas 2018 como base de testes, de sorte que os resultados não necessariamente espelham com exatidão os observados na base final.

Em síntese, a taxa média de desligamento é de $60 \%$, a mediana é de $50 \%$ e o desvio-padrão é de 45\%. É importante notar que o denominador é uma proxy, e, portanto, a taxa não deve ser interpretada literalmente. ${ }^{76} \mathrm{O}$ mais relevante aqui é observar que temos uma variação muito grande nas práticas de acolhimento e desligamento no território nacional, inclusive quando excluídos os casos extremos. Muitos fatores podem estar relacionados a essa variação, e propóe-se que estes sejam objeto de estudo específico. Mesmo que não possamos falar de causas sem ressalvas, a análise preliminar dos dados já aponta que alguns fatores esperados se correlacionam com a provisoriedade da permanência. A tabela 46 aponta a relação entre a faixa etária dos acolhidos e a taxa de desligamento. Dado que essa relação é suficientemente conhecida, o teste de hipótese serve para validar o indicador, que se mostra sensível à captação da relaçẫo apesar de os dados serem de tipo ecológico. ${ }^{77}$

76. Poderíamos melhorar a capacidade de interpretação da proxy multiplicando A por uma taxa que considere o número de meses que cada adolescente está acolhido em cada unidade - como feito anteriormente. No momento, não vemos utilidade para esse cálculo, de sorte que apenas apontamos a possibilidade de fazê-lo.

77. Isto é, temos dados por unidade, e não por acolhido. Assim, uma mesma unidade atende a diversas faixas etárias, o que gera um "ruído" na captação da relação entre as variáveis. Esse problema apenas poderia ser resolvido por meio do uso de microdados dos próprios acolhidos, algo que somente temos disponível para 2010. Uma solução possível para o Censo Suas seria incluir uma questão concernente ao retorno de ex-acolhidos para acolhimento. 
TABELA 46

Correlação entre proporção de acolhidos por faixa etária e taxa de desligamento (2018)

\begin{tabular}{lcc}
\hline Faixas etárias & $\begin{array}{c}\text { Correlação } \\
(r)\end{array}$ & $\begin{array}{c}\text { Significância } \\
(\mathrm{p})\end{array}$ \\
\hline Acolhidos 0 a 2 & .190 & .000 \\
Acolhidos 3 a 5 & .067 & .001 \\
Acolhidos 6 a 11 & .023 & .260 \\
Acolhidos 12 a 13 & -.027 & .194 \\
Acolhidos 14 a 15 & -.110 & .000 \\
Acolhidos 16 a 17 & -.087 & .000 \\
\hline
\end{tabular}

Fonte: Censo Suas 2018.

A tabela revela correlação significativa ${ }^{78}$ entre a faixa etária dos acolhidos e o desligamento. Unidades que acolhem adolescentes apresentam taxas mais baixas de desligamento - ou desinstitucionalização - do que as que recebem crianças. Entre as crianças, as maiores taxas estão naquelas que atendem à primeira infância e, em especial, o público de 0 a 2 anos. Como forma de confirmar a validade do achado, a tabela 47 apresenta, com base nos microdados individuais da pesquisa de 2010, a correlação entre as características dos acolhidos e o tempo de permanência destes.

TABELA 47

Correlação entre a idade do acolhido e o tempo de acolhimento institucional (2010)

\begin{tabular}{lcc}
\hline Características do acolhido & Correlação $(r)$ & Significância (p) \\
\hline Idade (meses) & .114 & .000 \\
\hline
\end{tabular}

Fonte: Levantamento Nacional (2010).

Os dados individualizados provam a forte relação entre idade e tempo de permanência, confirmando a relação captada por meio da taxa de desligamento. Dado o potencial desse indicador em apontar caminhos para o aprimoramento do SAI, recomenda-se que seja feito estudo específico sobre seus condicionantes institucionais.

\section{PERFIL DOS ACOLHIDOS ${ }^{79}$}

As pesquisas do Ipea-Conanda (Silva, 2004) e da Fiocruz-MDS (Assis e Farias, 2013), adotadas como referência para a análise deste relatório, trazem seçôes específicas sobre o perfil de crianças e adolescentes acolhidos, com um rol considerável de variáveis. O Censo Suas, todavia, contemplou apenas uma parte dessas informaçóes, dado seu foco em apurar o funcionamento dos serviços. Desde 2018, questóes mais relacionadas ao indivíduo atendido pelos serviços de acolhimento são coletadas pelo Prontuário Suas - Acolhimento para Crianças e Adolescentes. ${ }^{80}$

78. A correlação r é uma medida da força da correlação entre as variáveis e varia entre -1 (correlação negativa perfeita) e 1 (ou 100\%). A significância ( $p$ ) é a probabilidade de a correlação observada ser um erro estatístico e varia de 0 a 1 (ou 100\%). Testes $p$ com resultado inferior a 0,05 são considerados significativos, pois rejeitam a hipótese de que a correlação observada seja um erro estatístico com um grau de confiança de $95 \%$. Claro, quanto menor o $p$, maior a confiança, e quanto maior o $r$, mais forte é a correlação.

79. Na ausência de outras informações, esta seção analisará apenas os dados coletados pelo Censo Suas, que possibilita conhecer a distribuição territorial dos acolhidos, o sexo, a faixa etária e a quantidade de meninos e meninas provenientes de outros municípios.

80. Disponível em: <https://bit.ly/3cW5w00>. Acesso em: 29 abr. 2020. 
Informações sobre raça/cor, escolaridade, motivos da medida de acolhimento, renda familiar e vínculo dos acolhidos com sua família de origem são questôes fundamentais para avaliar se as condições socioeconômicas ainda são fatores determinantes para a institucionalização de crianças e adolescentes, mas que ainda não são coletadas pelo Censo Suas. As pesquisas anteriores revelaram a triste realidade de que as instituiçóes de acolhimento se constituíam em espaços para crianças e adolescentes negros, pobres e vítimas da violência estrutural que atinge, sobretudo, as famílias de baixa renda. A situação de maior vulnerabilidade das famílias potencializa outros fatores de risco e contribui para a maior exposição de crianças e adolescentes pobres à violência e à violação de direitos. Por esta razão, crianças e adolescentes em situaçáo de vulnerabilidade social apresentam tendência maior de vivenciarem períodos de institucionalização em suas trajetórias de vida. Ademais, os dados anteriores também mostraram que as instituiçóes de acolhimento constituíam opção real para a garantia dos direitos de alimentação e moradia para os filhos de pais e mães sem condiçóes materiais de prover os bens necessários para a sobrevivência digna de seus dependentes (Silva, 2004).

Dada a situação encontrada, a pesquisa realizada em 2003 questionava os limites dos abrigos no alcance da reintegração familiar de crianças e adolescentes sob sua guarda. Como em $24,1 \%$ dos casos a situaçáo de pobreza era motivo central para o afastamento do convívio com a família, e em 50,1\%, eram razóes relacionadas à pobreza/carência material (vivência de rua, exploração no trabalho ou mendicância), defendia-se que políticas públicas abrangentes, voltadas para fortalecer os vínculos familiares enquanto provedores dos direitos e cuidados de crianças e adolescentes, poderiam ter condiçóes de atuar na matriz da institucionalização dessa população, sobretudo na prevenção do afastamento do convívio familiar.

Como estratégia de superação desse problema, recomendava-se a realização de busca ativa entre as famílias dos acolhidos, a fim de inseri-las em programas de auxílio à renda, conforme preconizado no art. 23 do ECA. Após dezesseis anos, o Censo Suas de 2018 mostrou que apenas cerca de 4 mil famílias de crianças e adolescentes acolhidos recebem o benefício do PBF. Como o Censo Suas não apura os motivos do acolhimento, não se pode avaliar se essa quantidade de famílias cobertas pelo PBF está à altura da demanda. Assim seria importante capturar as informaçóes sobre motivos do acolhimento por meio do respectivo prontuário. A integração do Prontuário Suas - Acolhimento com o CadÚnico é muito importante para ter um retrato mais real se essas famílias estão acessando políticas de enfrentamento à pobreza. Além disso, é importante que a inclusão no CadÚnico seja sempre buscada, quando a criança e o adolescente receberem medida de acolhimento.

Da mesma forma, é fundamental que as famílias de crianças e adolescentes em situação de acolhimento tenham acesso ao Serviço de Proteção e Atendimento Especializado a Famílias e Indivíduos (Paefi), ofertado pelos Creas. Para que seja possível alcançar o objetivo da reintegraçáo familiar aqui, mais do que nunca, é preciso fazer valer o objetivo da PNAS de assegurar que as açóes no âmbito da assistência social tenham centralidade na família e garantam a convivência familiar e comunitária. A ampliação do acesso das famílias dos acolhidos a programas, projetos e benefícios ofertados pelo Suas, articulada com outras políticas públicas, é fundamental para a superação das situaçóes de risco social e violação de direitos vivenciados. Nesse sentido, cabe registrar que, como analisado anteriormente, se verifica, progressivamente, ampliaçáo da articulação entre os serviços de acolhimento, os Cras e os Creas. 


\subsection{Quantos são e onde estão}

Em 2018, o Censo Suas encontrou 33.032 crianças e adolescentes afastados do convívio familiar sob medida de proteção de acolhimento, conforme o art. 101, incisos VI e VII do ECA. Destes, 31,6 mil (96\%) viviam em 2.877 unidades de acolhimento e apenas 1,4 mil (4\%) estavam morando com famílias, na modalidade de acolhimento de famílias acolhedoras. Como pode ser observado pelo gráfico 31, a maior parte dos meninos e meninas acolhidos, tanto na modalidade institucional como familiar, estava nas regióes Sudeste e Sul. Juntas, essas duas regióes concentravam $72 \%$ de crianças e adolescentes sob medida protetiva de acolhimento institucional e $91 \%$ em acolhimento familiar. A participação das demais regiôes é bem menor. A região Nordeste é responsável por 15,2\% dos acolhidos em unidades e por $3,6 \%$ dos acolhidos em famílias acolhedoras. As regióes Centro-Oeste e Norte, conjuntamente, registravam menos de $20 \%$ do total de crianças e adolescentes acolhidos no país.

GRÁFICO 31

Distribuição de acolhidos em SAls e SAFs - Grandes Regiões (2018) (Em \%)

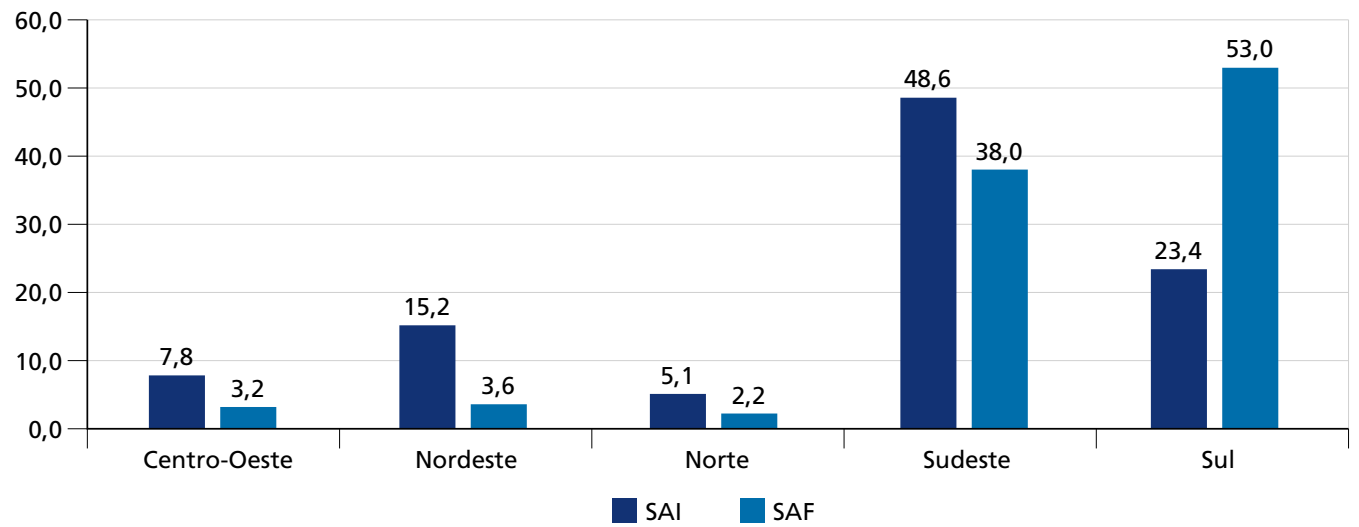

Fonte: Censo Suas 2018

Para fins de contextualização, retomamos aqui a análise realizada na subseção 4.1.1 deste relatório (tabela 2), a qual mostrou que as regiôes do país variam muito em relação à taxa de acolhidos por 100 mil crianças e adolescentes de 0 a 17 anos. ${ }^{81} \mathrm{Em} \mathrm{2018}$, a taxa nacional era de 59,1 acolhidos para cada 100 mil habitantes de 0 a 17 anos. Por sua vez, na regiáo Sul, essa taxa era da ordem de 107,1, quase o dobro da média nacional. Na regiáo Sudeste, tal taxa alcançou 75,3 e na região Centro-Oeste, 56,4. As regióes Norte e Nordeste foram aquelas que apresentaram as menores taxas de acolhimento em relação à média nacional: 26,7 e 29,8, respectivamente. Os resultados mostram ainda que, embora esta desigualdade ainda seja importante, ela foi reduzida no período analisado, a partir da indução do reordenamento dos serviços de acolhimento. 


\subsection{Idade e sexo}

Entre as crianças e adolescentes acolhidos em 2018, mais da metade estão nos grupos etários de 6 a 15 anos (56,4\%) (tabela 48). De um lado, observa-se que os programas de famílias acolhedoras, atendem, proporcionalmente, mais a população que está na primeira infância ( 0 a 5 anos) - com 37,9\% dos acolhidos nessa faixa etária -, enquanto nas unidades institucionais essa proporção é de $26 \%$. De outro lado, os SAIs acolhem proporcionalmente mais adolescentes de 12 a 17 anos - com 42,5\% dos acolhidos nessa faixa etária. Já, entre aqueles em acolhimento familiar, apenas 33,6\% são adolescentes. Essa distribuição de acolhidos entre ambas as modalidades traz à tona a necessidade de atentar-se às demandas de cada público para definir a melhor modalidade de acolhimento. $\mathrm{O}$ interessante é ter disponível nos territórios um rol de modalidades (acolhimento familiar, ou institucional - abrigo ou casa-lar). Tal como orientam os estudos e os regulamentos vigentes, deve-se priorizar a oferta do acolhimento familiar para o público de primeira infância.

TABELA 48

Crianças e adolescentes acolhidos por grupos de idade - Brasil (2018)

\begin{tabular}{lcrrrrr}
\hline Grupos de idade & SAF & $\%$ & SAI & $\%$ & Total & $\%$ \\
\hline 0 a 2 anos & 307 & 22,1 & 4.434 & 14,0 & $\mathbf{4 . 7 4 1}$ & $\mathbf{1 4 , 4}$ \\
3 a 5 anos & 220 & 15,8 & 3.798 & 12,0 & $\mathbf{4 . 0 1 8}$ & $\mathbf{1 2 , 2}$ \\
6 a 11 anos & 381 & 27,4 & 8.691 & 27,5 & $\mathbf{9 . 0 7 2}$ & $\mathbf{2 7 , 5}$ \\
12 a 15 anos & 325 & 23,3 & 9.228 & 29,2 & $\mathbf{9 . 5 5 3}$ & $\mathbf{2 8 , 9}$ \\
16 a 17 anos & 144 & 10,3 & 4.222 & 13,3 & $\mathbf{4 . 3 6 6}$ & $\mathbf{1 3 , 2}$ \\
18 a 21 anos & - & - & 538 & 1,7 & 538 & $\mathbf{1 , 6}$ \\
Mais de 21 anos & - & - & 729 & 2,1 & $\mathbf{7 2 9}$ & $\mathbf{2 , 2}$ \\
Sem informação & 15 & 1,1 & - & - & - & - \\
Total & $\mathbf{1 . 3 9 2}$ & $\mathbf{1 0 0 , 0}$ & $\mathbf{3 1 . 6 4 0}$ & $\mathbf{1 0 0 , 0}$ & $\mathbf{3 3 . 0 1 7}$ & $\mathbf{1 0 0 , 0}$ \\
\hline
\end{tabular}

Fonte: Censo Suas 2018.

Apesar de a medida de proteção de acolhimento ser aplicável apenas para a população até 17 anos, o Censo Suas encontrou 538 jovens (1,63\%) de 18 a 21 anos acolhidos e 729 $(2,21 \%)$ pessoas maiores de 22 anos vivendo em unidades de acolhimento voltadas para crianças e adolescentes. De acordo com o ECA, ao completarem 18 anos, os adolescentes devem deixar as instituições. Para tanto, há outro princípio no estatuto (art. 92) que prevê a preparaçáo gradativa para o desligamento por parte das unidades de acolhimento. Em geral, são jovens que passaram grande parte de suas vidas institucionalizados para os quais o SGDCA falhou em não conseguir reintegrá-los às famílias de origem ou em encaminhá-los para famílias substitutas. 
Como analisado anteriormente, quando se trata do serviço de repúblicas para jovens de 18 a 21 anos, muitos gestores têm dificuldades em promover o desligamento dos acolhidos porque não têm onde acomodar os egressos, uma vez que os serviços na modalidade repúblicas não estáo disponíveis para todos que destes necessitam. Assim, muitos dirigentes de unidades de acolhimento preferem manter os adolescentes nas próprias unidades até que ganhem autonomia. Por sua vez, a existência de 729 pessoas maiores de 21 anos nas instituiçóes de acolhimento para crianças e adolescentes necessita ser melhor investigada. Podem ser pessoas sem vínculo familiar e sem perspectivas de ganharem autonomia para uma vida fora da instituição, como são os casos de pessoas com deficiência severa com incapacidade para o exercício do trabalho remunerado, por exemplo. Nesse caso, seria importante o encaminhamento para o acesso a outros benefícios, como o PBF e o Benefício de Prestação Continuada (BPC), e a outros programas e benefícios ofertados pelo Suas, além da adoção de estratégias para o fortalecimento da autonomia e a preparaçáo gradativa para o desligamento do serviço de acolhimento.

Do total das crianças e adolescentes de 0 a 17 anos encontrados nos serviços de acolhimento institucionais e de famílias acolhedoras em 2018, 50,3\% eram meninas e 49,7\%, meninos. Conforme se observa pelos dados da tabela 49, em anos anteriores, a proporção de meninos acolhidos sempre foi maior do que de meninas. No entanto, a partir de 2014, observa-se leve tendência de queda na proporção de meninos acolhidos, caindo cerca de três pontos percentuais até 2018 , resultando em maior proporção de mulheres.

TABELA 49

Meninas e meninos acolhidos em SAls e SAFs

\begin{tabular}{llllll}
\hline \multirow{2}{*}{ Ano } & \multicolumn{3}{c}{ Meninas } & \multicolumn{3}{c}{ Meninos } & \multirow{2}{*}{ Total } \\
\cline { 2 - 3 } \cline { 5 - 6 } & Número & $\%$ & Número & $\%$ & \\
\hline 2010 & 17.498 & 47,7 & 19.209 & 52,3 & $\mathbf{3 6 . 7 5 5}$ \\
2012 & 15.651 & 46,5 & 18.033 & 53,5 & $\mathbf{3 3 . 7 3 0}$ \\
2014 & 16.256 & 47,5 & 17.972 & 52,4 & $\mathbf{3 4 . 2 7 5}$ \\
2016 & 15.842 & 48,8 & 16.590 & 51,1 & $\mathbf{3 2 . 4 8 1}$ \\
2018 & 15.902 & 50,3 & 15.689 & 49,6 & $\mathbf{3 1 . 6 4 1}$ \\
\hline
\end{tabular}

Fontes: Levantamento Nacional, 2010; e Censo Suas 2011, 2012, 2014, 2016 e 2018.

O gráfico 32 mostra a razáo de sexo ${ }^{82}$ da população de crianças e adolescentes acolhidos por grupo de idade para 2010, 2012, 2014, 2016 e 2018. Conforme se observa, em 2010 e 2012, em todos os grupos etários a razão de sexo era menor que 1 , acusando um número maior de crianças e adolescentes do sexo masculino. A partir de 2016, começa-se a notar a maior presença de meninas na população de acolhidos nos grupos etários correspondes à adolescência, a partir de 12 anos, quando a razáo de sexo é de 1,04 na faixa etária de 12 a 13 anos; 1,06, para o grupo de 14 a 15 anos; e igual a 1, para os acolhidos de 16 a 17 anos. Em 2018, essa tendência se repete, e a população de acolhidos traz, mais uma vez, maior número de meninas nos grupos de 12 a 13 anos; 14 a 15 e 16 a 17 anos; na razão de 1,15, 1,212 e 1,01; respectivamente.

82. 0 indicador razão de sexo representa a proporção de homens e mulheres na população de acolhidos, sendo que um número menor que 1 indica mais homens e maior que 1, mais mulheres. 
GRÁFICO 32

Razão de sexo das(os) meninas(os) acolhidas(os) - Brasil

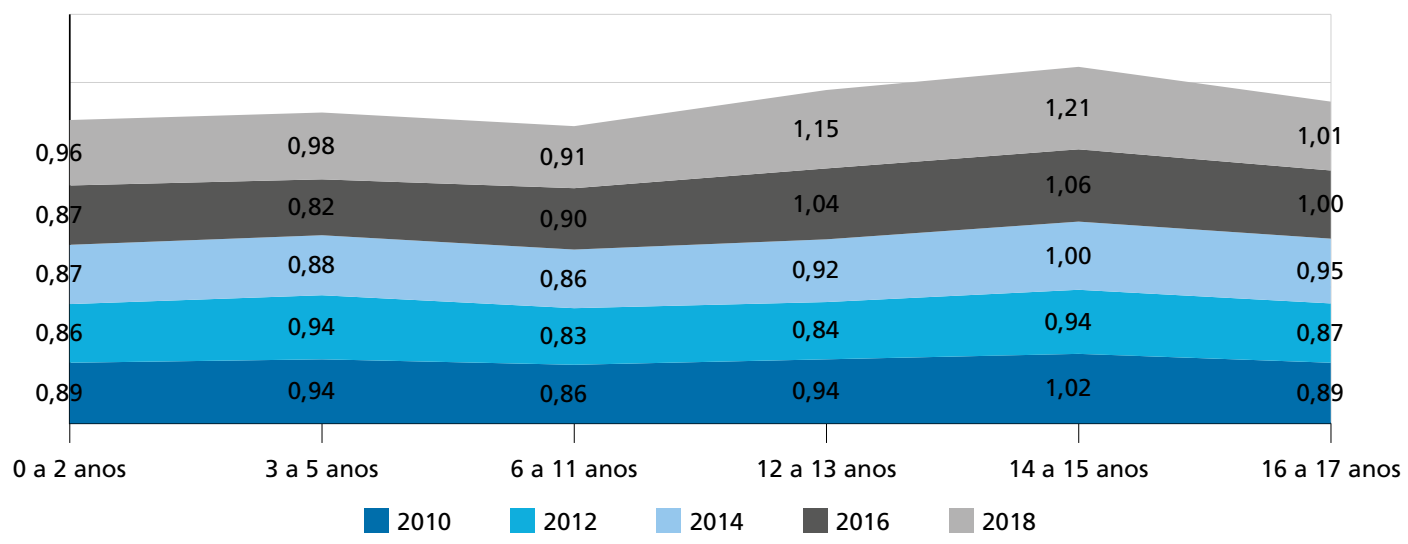

Fontes: Levantamento Nacional, 2010; e Censo Suas 2011, 2012, 2014, 2016 e 2018.

É importante registrar que a tendência de feminização da população de acolhidos, se confirmada, é novidade nas estatísticas dessa população que, em anos anteriores, trazia a presença majoritária de meninos nas faixas etárias superiores a 15 anos. Em 2004, por exemplo, os dados mostraram que quanto maior a idade, maior era a presença de meninos acolhidos. Na faixa etária de 16 a 18 anos, a razáo era de dois meninos para uma menina (Silva, 2004). Para compreender esse fenômeno, seria importante analisar o motivo do acolhimento, mas, como sinalizamos anteriormente, o Censo Suas não coleta essa informação. Como as violências física e sexual contra meninas são elevadas a partir de 12 anos, poderia pensar-se que a maior tendência de meninas nos serviços de acolhimento tenha relação com a maior identificação dessas situaçóes - pela atuação da rede de proteção, pela notificação compulsória, pelas políticas de saúde, educação e assistência social, pelas delegacias especializadas, pelos órgãos de defesa de direitos e pela denúncia, que tem sido muito estimulada nos últimos anos, a partir da contribuição do Disque $100 .^{83}$

\subsection{Acolhidos de outros municípios}

A falta de oferta do serviço é um dos principais motivos que levam ao acolhimento fora do município de residência da família de origem. O gráfico 33 mostra que, mesmo com alguma redução, 14\% dos acolhidos em SAIs (4.416) encontravam-se nessa situação em 2018. No caso do acolhimento familiar, esse problema é menor, alcançando 3,9\%. Com exceção de crianças e adolescentes ameaçados de morte, ${ }^{84}$ essa é uma decisão que deve ser evitada nas medidas judiciais de acolhimento, pois dificulta o processo de restauração dos vínculos familiares, a preservaçáo de vínculos comunitários, bem como o exercício do direito à convivência familiar e comunitária tão caros ao ECA e essenciais ao desenvolvimento da criança e do adolescente.

83. Trata-se de canal para registrar denúncias de violações de direitos humanos disponibilizado pela Ouvidoria Nacional de Direitos Humanos. Ver Relatório 2019, disponível em: <https://bit.ly/36zHVmn>.

84. Note-se que Ferraz et al. (2014, p. 277) indicam como uma dificuldade pungente na implementação do Programa de Proteção a Crianças e Adolescentes Ameaçados de Morte (PPCAAM) do Rio de Janeiro é, exatamente, "a ausência de um abrigo temporário para receber estes ameaçados ou a impossibilidade de mudança da família do local onde foi feita a ameaça". 
GRÁFICO 33

Acolhidos encaminhados de outros municípios - SAls, SAFs e Brasil ${ }^{1}$

(Em \%)

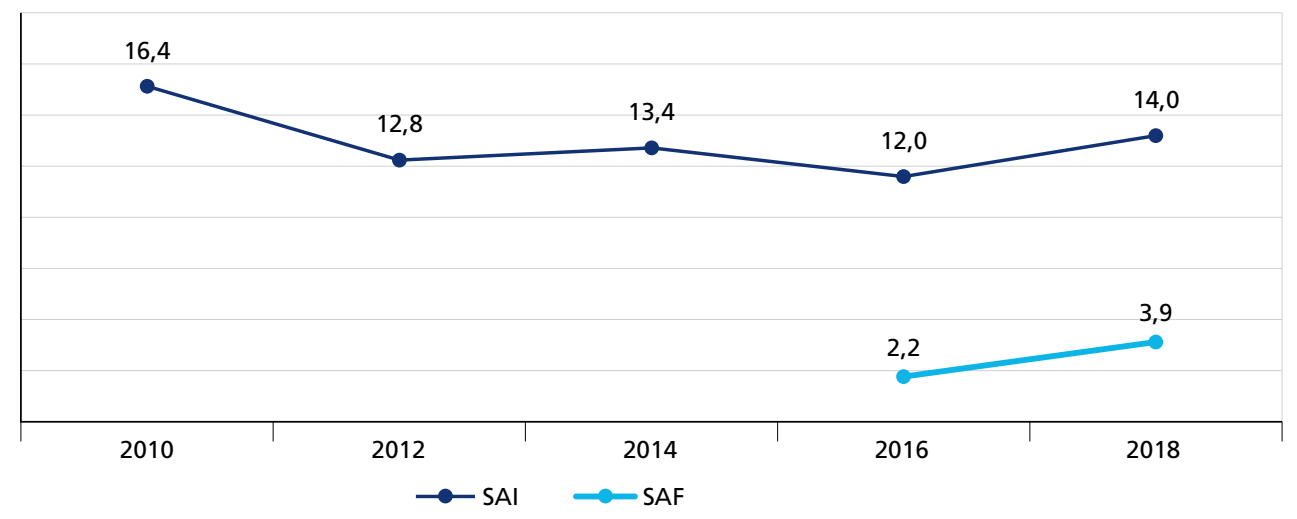

Fontes: Levantamento Nacional, 2010; e Censo Suas 2012, 2014, 2016 e 2018.

Nota: ${ }^{1}$ Não há dados disponíveis para SAFs em 2012 e 2014.

Assim, é importante que o processo de reordenamento das unidades de acolhimento contemple alternativas de proteção de crianças e adolescentes nos municípios que não contam com esses serviços. A persistência de crianças e adolescentes acolhidos em municípios diferentes daquele de origem pode ser mais um sinal de deficit de cobertura no interior do país. Dessa forma, cabe avançar no processo de regionalização da oferta, bem como ampliar os esforços para aumentar o número de famílias acolhedoras nos municípios menores, tal como já preconizam as Orientaçóes Técnicas (Brasil, 2009). Ademais, vale lembrar, essa modalidade de acolhimento não requer investimentos em estrutura física, mas em equipes técnicas para mobilizar, selecionar, capacitar e acompanhar as famílias acolhedoras cadastradas.

\subsection{Acolhidos com alguma das características identificadas pelo Censo Suas}

Uma das diretrizes do PNCFC trata do respeito à diversidade étnico-cultural, a identidade e orientação sexuais, à equidade de gênero e às particularidades das condiçóes físicas, sensoriais e mentais. Nesse sentido, as Orientaçóes Técnicas (Brasil, 2009) explicam como as necessidades específicas dos acolhidos devem ser abordadas pelos serviços de acolhimento:

Devem ser evitadas especializaçóes e atendimentos exclusivos - tais como adotar faixas etárias muito estreitas, direcionar o atendimento apenas a determinado sexo, atender exclusivamente ou não atender crianças e adolescentes com deficiência ou que vivam com HIV/AIDS. A atenção especializada, quando necessária, deverá ser assegurada por meio da articulação com a rede de serviços, a qual poderá contribuir, inclusive, para capacitação específica dos cuidadores.

O atendimento especializado, quando houver e se justificar pela possibilidade de atenção diferenciada a vulnerabilidades específicas, não deve prejudicar a convivência de crianças e adolescentes com vínculos de parentesco (irmãos, primos, etc.), nem se constituir em motivo de discriminação ou segregação (Brasil, 2009, p. 63). 
É desejável que as unidades de acolhimento destinadas à proteção da infância e da adolescência atendam em caráter universal qualquer pessoa com menos de 18 anos. As especificidades, caso existam, devem ser motivadas pela possibilidade de atençáo diferenciada a vulnerabilidades específicas - ou seja, para melhor atender ao superior interesse da criança e do adolescente, no sentido de personalizar e individualizar o atendimento, inclusive com metodologias mais adequadas às necessidades dos acolhidos, mas não para limitar o acesso ou a permanência de crianças e adolescentes por qualquer proveniência étnica, por problemas de saúde mental ou físico, ou ainda por identidade de gênero.

Vale lembrar que o Censo Suas capta a informação sobre as características dos acolhidos em cada serviço, os quais podem, eventualmente, abranger pessoas com 18 anos ou mais. Ainda que não seja possível extrair essa informação apenas para crianças e adolescentes, isso não impede a análise, visto que as informaçôes coletadas se referem, majoritariamente, à população de 0 a 17 anos. Esse segmento constitui mais de $90 \%$ dos acolhidos em todos os anos analisados. Em 2018, por exemplo, apenas 4\% do total de acolhidos tinham mais de 18 anos. O gráfico mostra que menos de um terço dos acolhidos (29,1\%) possuía alguma das características que indicam necessidade de articulação com políticas específicas para sua adequada abordagem (tabela 50).

GRÁFICO 34

Acolhidos com alguma das características identificadas pelo Censo Suas - Brasil (2018) (Em \%)

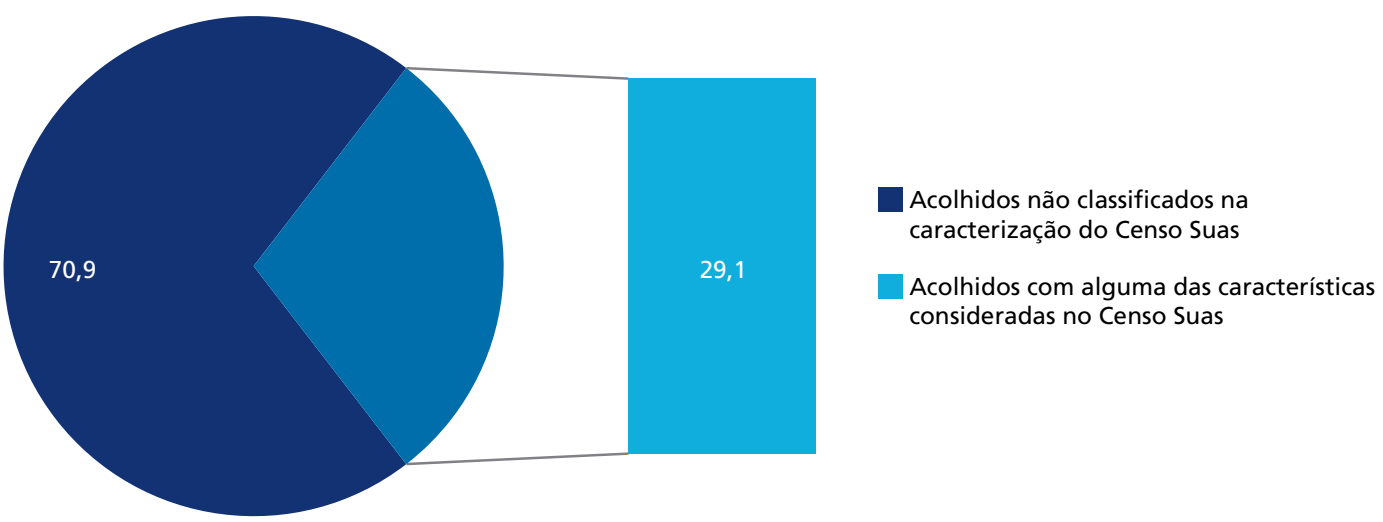

Fonte: Censo Suas 2018.

Na tabela 50, chama atenção o elevado percentual de acolhidos com deficiência física e mental, que juntos representam, em 2018, 16,8\% do universo de crianças e adolescentes acolhidos, ${ }^{85}$ o que mostra a importância de estreitar a relaçáo dos serviços de acolhimento com a rede de saúde. 
TABELA 50

Acolhidos com alguma das características mencionadas no Censo Suas - Brasil1

\begin{tabular}{|c|c|c|c|c|c|c|c|c|}
\hline \multirow{2}{*}{ Características dos acolhidos } & \multicolumn{2}{|c|}{2012} & \multicolumn{2}{|c|}{2014} & \multicolumn{2}{|c|}{2016} & \multicolumn{2}{|c|}{2018} \\
\hline & Número & $\%$ & Número & $\%$ & Número & $\%$ & Número & $\%$ \\
\hline Deficiência física, sensorial ou intelectual & 3.681 & 10,5 & 3.917 & 11,0 & 2.816 & 8,6 & 2.944 & 9,3 \\
\hline Doença/transtorno mental & - & - & 1.501 & 4,2 & 2.024 & 6,2 & 2.380 & 7,5 \\
\hline Refugiado/imigrante & 15 & 0,0 & 34 & 0,1 & 65 & 0,2 & 54 & 0,2 \\
\hline Travesti, transexual, transgênero e homossexual & - & - & - & - & 83 & 0,3 & 100 & 0,3 \\
\hline Cumprimento de medidas socioeducativas & - & - & - & - & - & - & 656 & 2,1 \\
\hline Trajetória de rua & 2.810 & 8,0 & 1.945 & 5,5 & - & - & 1.522 & 4,8 \\
\hline Indígenas & - & - & - & - & 175 & 0,5 & 171 & 0,5 \\
\hline Outros povos e comunidades tradicionais & - & - & - & - & - & - & 78 & 0,2 \\
\hline Dependência de álcool e outras drogas & 1.379 & 3,9 & 1.138 & 3,2 & - & - & 1.275 & 4,0 \\
\hline Vítimas de tráfico de pessoas & - & - & - & - & - & - & 21 & 0,1 \\
\hline Doenças crônicas & 513 & 1,5 & 697 & 2,0 & - & - & - & - \\
\hline Vítimas de calamidade ou situação de emergência & - & - & 259 & 0,7 & - & - & - & - \\
\hline $\begin{array}{l}\text { Idosos ou pessoas com deficiência que requeiram assistência } \\
\text { em todas as atividades de autocuidado para a vida diária e/ou } \\
\text { comprometimento cognitivo }\end{array}$ & 361 & 1,0 & 518 & 1,5 & - & - & - & - \\
\hline Total & 34.940 & - & 35.525 & - & 32.592 & - & 31.640 & - \\
\hline
\end{tabular}

Fontes: Censo Suas 2012, 2014, 2016 e 2018

Nota: ${ }^{1}$ As porcentagens apresentadas nessa tabela se referem ao total de pessoas acolhidas em SAls.

$\mathrm{O}$ atendimento adequado para crianças e adolescentes com deficiência física e/ou intelectual requer dotar as unidades de acolhimento de equipe técnica capacitada e também de estrutura física com acessibilidade. De acordo com dados do Censo Suas, em 2018, $87,6 \%$ dos serviços de acolhimento declararam que recebiam crianças e adolescentes com deficiência física, sensorial ou intelectual e $80,1 \%$, com transtorno mental. No entanto, conforme mostram os dados apresentados pela tabela 38 - na subseção 7.1 deste relatório -, em 2018, apenas $30,4 \%$ dos serviços contavam com rotas acessíveis aos espaços coletivos e dormitórios e apenas $23 \%$ destes tinham banheiros adaptados para pessoa com deficiência, conforme estabelecido pela ABNT. Nos casos de crianças e adolescentes com transtornos mentais e/ou que apresentam problemas devido ao uso abusivo de álcool - nesse último caso, sem variaçóes significativas entre 2010 e 2018 -, o serviço de acolhimento deve poder contar com suporte da rede de saúde mental no Centro de Atenção Psicossocial (Caps) ${ }^{86}$ ou, onde houver, o Centro de Atenção Psicossocial Infanto-juvenil (CAPSi), ${ }^{87}$ especializado no atendimento de crianças e adolescentes com transtornos mentais graves (autismo, psicoses, neuroses graves, abuso ou dependência de álcool e outras drogas). Garantir atendimento especializado a crianças e adolescentes nessa condição em serviços de acolhimento é, portanto, um dos desafios a serem enfrentados no processo de atualização do PNCFC.

86. Caps são serviços extra hospitalares, de atenção diária, de base comunitária e que possuem equipe multiprofissional. Os Caps têm papel estratégico no que se refere à regulação da porta de entrada da rede assistencial de saúde mental e devem ser lugares de referência e tratamento para pessoas que sofrem com transtornos mentais e/ou que apresentam problemas devido ao uso abusivo de álcool e outras drogas, promovendo a inserção social de seus usuários por meio de ações intersetoriais e oferecendo suporte à atenção à saúde mental na rede básica de saúde.

87. CAPSi é um serviço de atenção diária destinado ao atendimento de crianças e adolescentes com transtornos mentais graves. Estão incluídos nessa categoria os portadores de autismo, psicoses, neuroses graves, usuários de álcool e outras drogas e todos aqueles que, por sua condição psíquica, estão impossibilitados de manter ou estabelecer laços sociais. A experiência acumulada em serviços que já funcionavam segundo a lógica da atenção diária indica que se ampliam as possibilidades do tratamento para crianças e adolescentes quando 0 atendimento tem início o mais cedo possível, devendo, portanto, os CAPSi determinarem as parcerias necessárias com as redes de saúde, educação e assistência social ligadas ao cuidado da população infanto-juvenil. 
Nota-se na tabela 50 redução importante no percentual de crianças e adolescentes acolhidos em trajetória de rua, que de $8 \%$, em 2012, passou a 4,8\% dos acolhidos, em 2018. Para esse subgrupo, os cadastros de crianças e adolescentes desaparecidos devem ser consultados. Nessas situaçôes, deve-se buscar analisar junto à criança ou ao adolescente sua situação familiar, os motivos que levaram à saída de casa e o desejo de retomada do contato com familiares, sobretudo com aqueles que a estiverem procurando. No caso específico de crianças e adolescentes que estejam em situação de rua, a acolhida inicial deve fazer parte de estratégia de sensibilização para o acolhimento no serviço e a construçáo de vínculo de confiança com este. Ao longo do processo de trabalho pela saída da rua, além dos aspectos aqui mencionados, deve-se trabalhar também o significado do "estar e não-estar na rua", expectativas, desejos e temores quanto à retomada do convívio familiar e social, entre outros aspectos (Brasil, 2009). ${ }^{88}$

Em 2018, foi apurado pela primeira vez o número de adolescentes acolhidos que estavam em cumprimento de medida socioeducativa, que alcançava $2,1 \%$ do total. Nesse caso, o adolescente está sob dupla medida protetiva (medida de acolhimento e medida socioeducativa para o adolescente em conflito com a lei), o que requer também atenção redobrada dos gestores do serviço. A Resoluçáo CNAS nº 18/2014 estabelece que os adolescentes em cumprimento de medidas socioeducativas em meio aberto, de liberdade assistida e de prestação de serviço para a comunidade constituem público prioritário do Serviço de Convivência e Fortalecimento de Vínculos (SCFV), a fim de reforçar a convivência familiar, comunitária e social. Além do SCFV, as famílias desses adolescentes também têm prioridade no Paefi e no Serviço de Proteção e Atendimento Integral à Família (Paif).

\section{CONCLUSÃO}

Catorze anos após a publicação do PNCFC e trinta anos após a promulgação do ECA, muitos atributos dos serviços de acolhimento mudaram para melhor, com destaque para a ampliação da oferta dos serviços; a criação de novas modalidades de atendimento; a redução do tamanho das unidades; o cumprimento do atendimento em pequenos grupos; a maior articulação das unidades de acolhimento com a rede de serviços que promovem o acesso aos direitos sociais presentes nos municípios; a redução do tempo médio de permanência nos SAIs; além da existência de mecanismos de monitoramento dos serviços, que realizam, entre outros atributos, a coleta periódica e qualificada de informaçóes qualificadas por meio do Censo Suas. Esses são apenas alguns dos exemplos de melhorias que a implementaçáo da medida protetiva de acolhimento no Brasil assistiu nesta década e meia transcorrida após a elaboração do PNCFC.

Tais avanços são tributários da atuação de diversos atores, incluindo-se, entre outros, o Suas, o sistema de Justiça e das organizaçôes e atores da sociedade civil defensoras dos direitos da infância e da adolescência, que se mobilizaram fortemente desde antes da elaboração do PNCFC, participaram da sua elaboração e continuaram atuantes no processo de sua implementação. Importante também reconhecer que essas conquistas integraram a PNAS em 2004 e foram determinantes para substituir a tendência assistencialista do acolhimento de crianças e adolescentes afastados da convivência familiar por propostas de caráter socioeducativas e emancipatórias, com foco no fortalecimento dos vínculos familiares e comunitários e na garantia do superior interesse das crianças e dos adolescentes.

88. As Orientações Técnicas para acolhimento de crianças e adolescentes em situação de rua foram atualizadas pela Resolução Conjunta CNAS-Conanda no 1, de 15 de dezembro de 2016. 
O diagnóstico de que houve avanços após a elaboração do PNCFC caminha lado a lado ao reconhecimento de que há ainda muitos desafios a serem vencidos até que o direito à convivência familiar e comunitária seja uma realidade para milhares de crianças e adolescentes que necessitam dos serviços de acolhimento no Brasil, como a expansão da cobertura do serviço para as regióes Norte e Nordeste, além da ampliação do acolhimento familiar e das repúblicas para jovens egressos do acolhimento por questáo de maioridade.

Todavia, antes de entrar na questão dos serviços propriamente, cabem algumas palavras sobre o perfil de crianças e adolescentes acolhidos. O Censo Suas traz poucas informaçóes sobre as características destes, uma vez que a unidade de análise do questionário são os serviços de acolhimento, e náo necessariamente o público atendido. Em 2018, encontramos 31,7 mil crianças e adolescentes afastados do convívio familiar sob medida de proteção de acolhimento, sendo que mais de 70\% viviam nos serviços ofertados nas regiōes Sudeste e Sul. Como não existem informaçôes sobre rendimento da família de origem e os motivos do acolhimento, não foi possível avaliar se as condiçóes socioeconômicas ainda são fatores determinantes para a institucionalização, como mostraram as pesquisas realizadas anteriormente. A ampliação do acesso das famílias dos acolhidos aos programas, projetos e benefícios ofertados pelo Suas, articulada com outras políticas públicas, é fundamental para a superaçáo das situaçóes de risco social e de violação de direitos vivenciados por essa população no âmbito de suas famílias e na comunidade em que vivem.

Em 2018, mais da metade dos acolhidos tinha entre 6 e 15 anos de idade, sendo que $27,48 \%$ estavam no grupo etário de 6 a 11 anos e 28,93\% no grupo de 12 a 15 anos. Apesar da medida de proteção de acolhimento ser aplicável apenas para a população de até 17 anos, o Censo Suas encontrou, em 2018, 538 jovens (1,63\%) de 18 a 21 anos acolhidos, que já deveriam ter sido transferidos para repúblicas, e 729 pessoas maiores de 22 anos, que, provavelmente, eram adultos sem vínculos familiares e sem perspectivas de ganharem autonomia para uma vida fora da instituição, como são os casos de pessoas com deficiência física ou intelectual severa. Aliás, o Censo Suas encontrou proporção expressiva (16,8\%) de crianças e adolescentes com algum tipo de deficiência física e/ou mental vivendo nas unidades de acolhimento em todo o Brasil, em 2018. Apesar de mais de $80 \%$ das unidades de acolhimento terem declarado que recebem crianças e adolescentes com deficiência, apenas cerca de um terço destas contava com rotas acessíveis aos espaços coletivos e dormitórios, de acordo com as normas da ABNT. Esses dados revelam a importância de dotar os serviços de acolhimento de equipe técnica capacitada e, igualmente, de estrutura física com acessibilidade, viabilizando inclusive a qualificação do acolhimento de longa permanência para determinados casos e o manejo adequado das situaçóes em que o acolhido atinge a maioridade no serviço, além da necessidade de manter articulação estreita com a rede de saúde. Dessa forma, coloca-se como um dos desafios para atualização do PNCFC a adequação dos serviços de acolhimento para o público com deficiências de diversas ordens e também com transtornos mentais, vislumbrando alternativas mais adequadas a seu atendimento.

Apesar da redução em relação a anos anteriores, o Censo Suas de 2018 ainda encontrou $14 \%$ de crianças e adolescentes vivendo em instituiçóes distantes dos municípios de suas famílias, sendo 3,9\% no caso das famílias acolhedoras. Isso ocorre porque ainda existem municípios, sobretudo de pequeno porte, que náo contam com oferta de serviços de acolhimento, com grandes extensóes de "vazios" de oferta nas regióes Norte e Nordeste. 
Importante destacar ainda que, desde 2014, observa-se crescimento relativamente maior no número de meninas entre os adolescentes acolhidos, uma novidade nas estatísticas dessa população que, em anos anteriores, trazia a presença majoritária de adolescentes do sexo masculino. Embora os dados disponíveis náo permitam entender as razóes que estáo levando ao aumento das meninas acolhidas, cabe atentar para a eventual necessidade de adequaçáo dos serviços para atendimento de um público majoritariamente feminino.

É com foco nesse perfil dos acolhidos que este relatório buscou ampliar o conhecimento sobre o conjunto de serviços que executam a medida protetiva de acolhimento prevista no ECA. Para tanto, o reordenamento dos serviços de acolhimento e a implementaçáo de novas modalidades de atendimento (famílias acolhedoras e repúblicas) foram analisados à luz do ECA e do PNCFC, além de regulamentações complementares - Orientações Técnicas (Brasil, 2009) e resoluções de reordenamento e regionalização, de 2013. As fontes primárias de informação consistiram nos bancos de dados do Censo Suas para 2012, 2014, 2016 e 2018, ao que se somaram, quando possível, dados do Levantamento Nacional de 2010 (Assis e Farias, 2013).

Em termos institucionais, temos que as diretrizes de cada modalidade de acolhimento (abrigos/casas-lares, família acolhedora e repúblicas) são distintas. Dessa forma, distintos também são os pontos que merecem destaque, os desafios identificados e as eventuais recomendaçôes de aprimoramento por ocasiáo da atualização do PNCFC.

\subsection{Acolhimento familiar para crianças e adolescentes}

No caso dos SAFs, os avanços logrados a partir do PNCFC são bem mais tímidos que os resultados do reordenamento do acolhimento institucional. Os progressos mais significativos desse tipo de serviço restringiram-se ao campo normativo. De um lado, a Lei no 12.012/2009 inseriu no art. 34, $\$ 1^{\circ}$ do ECA o acolhimento familiar como preferencial ao institucional. Além disso, mudanças recentes nesse mesmo estatuto criaram melhores condiçóes para a expansão do serviço, inclusive com permissão para que fossem destinados repasses de recursos do cofinanciamento federal diretamente às famílias acolhedoras. De outro lado, a cobertura dos SAFs em 2018 segue bastante incipiente, mediante a qual 333 serviços alcançam 1.392 crianças e adolescentes (pouco mais de 4\% do total de acolhidos). Embora tenha ensaiado uma expansão a partir de 2012, a oferta de SAFs encolheu-se nos anos seguintes, alcançando em 2018 um patamar não muito superior ao de 2010. A distribuição regional dos SAFs também segue desigual, com mais de $80 \%$ da oferta nas regióes Sudeste e Sul, sendo que $45,3 \%$ apenas na região Sul.

Portanto, um dos principais desafios a serem enfrentados no processo de atualização do PNCFC consiste justamente em ampliar o modelo de atendimento em acolhimento institucional para o acolhimento familiar (Pereira, Neris e Melo, 2019), de modo a reduzir o hiato entre a lei e a realidade. Esse serviço pode ser especialmente benéfico no caso das crianças na primeira infância, para as quais são reconhecidos os potenciais efeitos danosos da institucionalização no desenvolvimento infantil, e para crianças e adolescentes com deficiência, que exigem cuidados mais individualizados. Mas, de modo geral, podem beneficiar diferentes faixas etárias, viabilizando o convívio em ambiente familiar e na comunidade, enquanto a medida protetiva de acolhimento se mostrar necessária. Ademais, indica-se a necessidade de estímulos mais direcionados às regióes Norte, Nordeste e Centro-Oeste, 
especialmente em municípios de pequeno porte, nos quais o acolhimento familiar ainda não conquistou aderência da rede socioassistencial.

\subsection{Acolhimento institucional para crianças e adolescentes}

O reordenamento do serviço de acolhimento institucional tem mudado sua face. Se antes era predominantemente oferecido por OSCs, têm cada vez mais se sobressaído as ofertas públicas laica $(74,8 \%)$ e governamental $(53 \%) .{ }^{89} \mathrm{O}$ abrigo institucional continua a modalidade mais frequente, contemplando $71,8 \%$ dos SAIs em 2018, enquanto as casas-lares correspondiam a $26,5 \%$.

Em 2018, tínhamos 253 serviços de SAI a mais do que em 2010 (+ 9,6\%). O acolhimento institucional estava presente em 1.710 municípios; 553 a mais que em 2010 (+ 47,8\%). O período mais profícuo de ampliação desses serviços ocorreu entre 2004 e 2013, no bojo de mudanças institucionais que envolveram não apenas a elaboração do PNCFC (2006) e mudanças no ECA, mas também a criação e a consolidação do próprio Suas. O processo de reordenamento dos serviços ganhou reforço em termos de instrumentos de coordenaçáo mediante o aumento do cofinanciamento federal, que, por sua vez, inaugurou, a partir de 2013, uma fase de qualificação da oferta. Vale ressaltar, no entanto, que a redução no número médio acolhidos por SAIs já havia se iniciado entre 2010 e 2012 (de 15,2 para 14), logo após a publicação das Orientaçôes Técnicas (Brasil, 2009) e um pouco antes da ampliação do incentivo financeiro ao processo de reordenamento, que somente ocorreu a partir da Resolução no 23/2013. Essa constatação sugere que a definição de parâmetros nacionais para oferta dos serviços já repercutia na sua realidade antes mesmo que os respectivos mecanismos de cofinanciamento fossem revistos.

A taxa de incidência do serviço - medida pela taxa de acolhidos por 100 mil habitantes (de 0 a 17 anos) - reduziu-se em 9,9\% entre 2010 e 2018, indicando que essa medida tem sido adotada mais criteriosamente e indo ao encontro da sua excepcionalidade e provisoriedade definidas pelo ECA (art. 101, $\$ 1 \stackrel{\circ}{\circ}$ ). Essa queda é explicada principalmente pela região Sudeste, que, historicamente, concentra a oferta do serviço no país. Tanto a incidência quanto a capacidade instalada - esta medida pela oferta de vagas por 100 mil habitantes (de 0 a 17 anos) - se expandiram nas regióes Norte e Nordeste, que continham menor densidade em ambos os indicadores em 2010. Todas as regióes do país superaram, em 2018, o patamar de cinquenta vagas por 100 mil habitantes de 0 a 17 anos, de modo que o serviço, quando existe, oferece cobertura segundo tal parâmetro definido no processo de reordenamento. Apenas 3,3\% dos municípios com SAIs possuem oferta inferior a esse patamar.

Se a quantidade de SAIs aumentou em todas as regióes, a média nacional de acolhidos por esse tipo de serviço tem caído gradualmente, passando de 15,2, em 2010, para 10,6, em 2018. Ademais, verifica-se reduçáo na quantidade de serviços que operam acima da respectiva capacidade sugerida pelas normativas, de 541 (25,7\%), em 2010, para $336(11,9 \%)$, em 2018. Essa queda ocorreu em municípios de todos os portes em todas as regióes, sendo mais intensa nas metrópoles e na região Sudeste. 
Duas tendências são, portanto, observadas no período analisado: tanto os novos serviços estão operando com capacidade inferior ao limite atribuído pelas Orientaçóes Técnicas (Brasil, 2009), como os "antigos" serviços estão sendo adaptados - e reduzidos - segundo tais parâmetros. Em síntese, os serviços de acolhimento têm se organizado para atender a um número menor de crianças e adolescentes, indo ao encontro do princípio que prescreve o atendimento individualizado e em pequenos grupos (art. 92, inciso III do ECA).

Todavia, em que pesem os inequívocos avanços, permanecem desafios a serem enfrentados por ocasião da revisão do PNCFC. A distribuição dos SAIs entre as regióes segue heterogênea. Sul e Sudeste ainda concentram as vagas (69,3\%), os acolhidos $(72,4 \%)$ e os serviços $(82,2 \%)$. Embora os municípios que mais tenham se beneficiado da criação de novos SAIs estejam nas regióes Nordeste $(+129,4 \%)$ e Norte $(+95,1 \%)$, seu deficit em relação às demais regióes ainda é significativo, fazendo-se necessário repensar estratégias que ampliem a cobertura da oferta de serviços de acolhimento nesses territórios, as quais náo devem estar descoladas da necessária ampliaçáo da prevalência do modelo institucional para o familiar no Brasil, conforme previsão legal. Seria importante estudar os fatores que levam às regióes do país a apresentarem tanta disparidade, entre os quais podemos destacar: i) distintas tendências de aplicação da medida de acolhimento por parte de autoridades judiciárias, em detrimento de outras medidas previstas no ECA; ii) eventuais dificuldades enfrentadas pelos serviços de acolhimento na promoção da reintegração familiar via família de origem ou adoçáo; e iii) efetiva disponibilidade da oferta de serviços de acolhimento no território perante a demanda apresentada.

A estratégia de regionalização é outro aspecto do reordenamento que merece ser revisto. A partir de 2013, a gestão estadual responsabilizou-se por organizar a oferta de serviços de acolhimento para municípios sem oferta própria suficiente para atender à própria demanda. Antes disso, em 2010, os governos estaduais chegaram a ofertar 86 SAIs próprios, com 1.275 acolhidos, operados em vinte UFs. No entanto, em 2018, havia apenas 22 serviços estaduais, com 508 acolhidos, restritos a oito estados. Ou seja, além de desincumbirem-se da oferta própria de SAIs, cada vez menos os entes estaduais têm optado por essa forma de suprir a demanda dos municípios de menor porte.

Preocupa o fato de, em 2018, 16\% dos que estáo em atendimento nos SAIs estejam em unidades com mais acolhidos do que vagas disponíveis. Algo também parece ocorrer em relação às casas-lares, cuja própria média de vagas disponibilizadas $(12,7)$ extrapola o limite definido para essa modalidade de SAI, fixado em dez vagas. É fundamental investigar o perfil dessas unidades para distinguir as causas possíveis; afinal, um número de usuários superior à capacidade do equipamento dificulta a prestaçáo adequada do serviço.

No que tange à oferta do serviço em si, o período analisado caracteriza-se pela maior frequência na promoção de atividades como a orientaçáo familiar, a reuniáo com grupo de famílias e a visitação da equipe técnica à família do acolhido. Além disso, os dados apontam para um crescimento das inter-relaçóes entre as unidades de acolhimento e os órgãos do SGDCA. Tal movimento vai ao encontro dos princípios do direito à convivência familiar e da abertura institucional preconizados no PNCFC. No caso do Judiciário, o percentual de visitas é, ainda, bastante baixo. Por sua vez, o envio de relatórios semestrais ao Judiciário por parte das unidades - recomendação do próprio PNCFC e exigência legal - avançou fortemente nos últimos anos, chegando a uma quase universalização da atividade em 2018. 
Observa-se também uma abertura cada vez maior das unidades para os conselhos tutelares, os Cras, os Creas e os serviços de educação e de saúde de forma geral.

Ainda assim, as unidades de acolhimento seguem insuficientemente integradas ao SGDCA como um todo. Devem ser envidados maiores esforços para sua integraçáo, os quais poderiam ser potencializados pelo estabelecimento de protocolos mínimos de entendimento entre as instâncias no nível nacional (CNJ, CNMP, Defensoria Pública da União - DPU, MMFDH e SNAS/MC), com o objetivo de definir responsabilidades e de facilitação da atuação coordenada na ponta, inclusive com intercâmbio de dados e informaçóes, como apontado anteriormente. É digno de nota, particularmente, a articulaçáo com o Creas, tanto pelo crescimento observado nos últimos anos nos contatos entre SAIs e Creas, como pelo potencial de solidificar o referenciamento dos abrigos e casas-lares no âmbito do Suas, a partir da incorporação de protocolos mais claros de corresponsabilidade.

No que tange à responsabilidade do poder público em promover os direitos básicos de indivíduos em fase peculiar de desenvolvimento sob sua tutela, observa-se crescimento na participação das crianças e adolescentes nas tomadas de decisóes que dizem respeito às suas vidas, ainda que não tenhamos informaçóes acerca de como essa participação se dá - o que também poderia ser objeto de investigação específica. De qualquer sorte, os PIAs destacam-se como instrumento fundamental à prestaçáo de um serviço mais humanizado. Chama atenção, entretanto, que a convivência familiar e comunitária nem sempre seja objeto central desses planos: em 2014, 19,5\% destes náo registraram vínculos comunitários; 11,4\% não registraram relacionamentos intrafamiliares; $14 \%$ não planejaram a participação da família de origem durante o acolhimento; 13,2\% não previram o acompanhamento da família de origem; e 31,5\% não envolveram um plano de ação com a família do acolhido.

Sobre o tempo de acolhimento de crianças e adolescentes, alguns achados se destacam. Em primeiro lugar, observa-se que, ao longo dos anos, há crescimento contínuo da proporçáo de acolhidos com tempo de permanência inferior a um ano, assim como queda progressiva daqueles acolhidos por mais de dois anos. Em segundo lugar, constata-se que existe correlação entre um menor tempo de acolhimento e a realizaçáo, pela unidade, de certas atividades. Entre estas, destacam-se: i) as visitas domiciliares às famílias dos acolhidos; ii) a realização de reunióes com grupos de famílias; iii) o atendimento psicossocial individualizado; iv) o acompanhamento escolar; e v) a participação dos acolhidos na discussão das rotinas da unidade. Nota-se, por fim, uma correlação entre tempo médio de permanência na unidade e o acompanhamento dos acolhidos após seu desligamento. Unidades que náo realizam e/ ou não sabem se esse acompanhamento é realizado por alguma outra instituição ou órgão têm tempo de permanência maior.

Com relação ao acompanhamento do desligamento, três questóes são importantes: quem o faz; por quanto tempo; e de que forma. Infelizmente, não temos informaçóes que nos auxiliem a responder a terceira questão, tema que seria interessante incorporar em edição futura do Censo Suas. Com relação ao tempo, observa-se que 73,7\% afirmaram acompanhar os acolhidos por um período médio de seis meses em 2018. Esse resultado converge - e ao mesmo tempo pode ser reflexo do - para o respeito ao parâmetro proposto pelas Orientaçóes Técnicas do serviço (Brasil, 2009). Finalmente, ainda sobre o acompanhamento após o desligamento, é importante mencionar que parte dos gargalos existentes 
nesse tipo de atividade poderiam ser contornados com a integração de informaçóes de bases de dados do MC (Prontuário Suas - Acolhimento e CadÚnico) e do CNJ (SNA). Dessa maneira, seria possível contar com uma ferramenta ágil e prática de monitoramento das trajetórias das crianças e dos adolescentes acolhidos, além da identificação de fatores que podem favorecer ou dificultar a retomada exitosa do convívio familiar - pela reintegração familiar ou adoção.

CPara além de adentrar as especificidades do acolhimento institucional ou familiar de crianças e adolescentes afastados da convivência com a família de origem, vale registrar, enfim, a cobertura significativa alcançada por esses serviços. Em 2018, 2.010 municípios $(36,1 \%)$ contavam com alguma oferta, os quais cobriam $80,3 \%$ da populaçáo brasileira. Os perfis de oferta encontrados foram os mais variados. A maior parte (1.488) ofertava apenas SAIs. Alguns (167) ofereciam apenas SAFs. Outros (132) não possuíam oferta própria, mas estavam vinculados a alguma oferta regionalizada. Embora menos frequente, foi possível encontrar municípios com perfis mistos de oferta.

Ainda que a cobertura em termos de vagas revele que os serviços de acolhimento de crianças e adolescentes cubram boa parte do seu público-alvo, segundo o parâmetro de cinquenta vagas para cada 100 mil habitantes de 0 a 17 anos (medido apenas para SAIs neste relatório), a oferta do serviço continua como exceção nos municípios menores. A maior parte dos 3.560 municípios que náo possui oferta alguma são de pequeno porte I ( $86 \%)$ e II (12,8\%), com vazios de oferta encontrados sobretudo nas regióes Norte e Nordeste, mesmo que estas sejam as regióes que mais criaram serviços e vagas entre 2010 e 2018. Apontar estratégias para fazer chegar o serviço de acolhimento de crianças e adolescentes aos 19,7\% da população que residem nesses municípios restantes é, desse modo, outro desafio importante que a atualização do PNCFC deve enfrentar. Avanços nessa direção não podem estar descolados da priorizaçáo prevista no estatuto do acolhimento em famílias acolhedoras.

\subsection{Serviço de acolhimento para egressos dos serviços de acolhimentos de crianças e adolescentes}

Os resultados encontrados sobre a implantação dos serviços de repúblicas para jovens de 18 a 21 anos foram pouco alentadores. Em 2018, existiam apenas trinta unidades desse serviço em todo o Brasil. Somente 19 municípios ofertavam essa modalidade, que estavam presentes em apenas nove estados e três regióes. Nas regióes Norte e Centro-Oeste, o Censo Suas não registrou nenhuma unidade. A insignificante oferta desse serviço está em flagrante desacordo com as Orientaçóes Técnicas para os serviços de acolhimento de crianças e adolescentes (Brasil, 2009), aprovadas em 2009 pelo Conanda e pelo CNAS, e com as necessidades de proteção desses jovens. Apesar de as Orientaçóes Técnicas destacarem não ser necessária a instalação de repúblicas em municípios com demanda insuficiente, estas também estabelecem que, nesse caso, deve existir oferta em localidades próximas às unidades onde os jovens estavam acolhidos. Além disso, os jovens devem receber os meios necessários para visitarem seu antigo município, a fim de que sejam mantidos seus laços de convivência.

Em relação às vagas ofertadas e à quantidade de jovens acolhidos nas repúblicas existentes, os dados revelaram a existência de ociosidade na ocupação. Essa característica foi observada em todas as regióes, exceto nas regióes Norte, e Centro-Oeste, em que náo foi identificada oferta alguma desse serviço. De um total de 244 vagas ofertadas, apenas cerca 
de $60 \%$ estavam ocupadas, o que não se coaduna com a quantidade de jovens maiores de 18 a 21 anos (538) que ainda se encontravam vivendo em serviços de acolhimento para crianças e adolescentes de todo o Brasil. Em vista disso, a análise levanta três hipóteses náo excludentes que podem explicar esse aparente paradoxo. A primeira é que as vagas ociosas podem estar localizadas em municípios distantes dos serviços de acolhimento nos quais se encontram acolhidos os jovens maiores de 18 anos, inviabilizando a transferência deles. A segunda refere-se às dificuldades enfrentadas pelas equipes técnicas nas tarefas de preparaçáo gradativa, dos adolescentes para a vida fora da instituição. $\mathrm{E}$, finalmente, a terceira remete à preferência dos adolescentes e jovens acolhidos. Nesse caso, é possível que as repúblicas sejam pouco atrativas como moradia aos jovens, ao ponto em que esses prefiram buscar, por conta própria, outras alternativas de moradia.

A preparação para o desligamento pelo alcance da maioridade requer que as equipes técnicas consigam ampliar a escolaridade e a qualificação profissional dos adolescentes, a fim de aumentar suas chances de empregabilidade. Dessa forma, preparar os adolescentes para a vida autônoma fora da instituição não é tarefa fácil, inclusive pelas maiores dificuldades emocionais devido ao elevado tempo que passaram institucionalizados. Os dados do Censo Suas 2018 revelaram grande diversidade nas açóes desenvolvidas para os jovens que vivem nas repúblicas. Todavia, a partir dos dados disponíveis, não foi possível identificar esforço importante no desenvolvimento de açóes de qualificaçáo e capacitaçáo profissional que pudessem aumentar a empregabilidade deles e, com isso, contribuírem para sua independência e autonomia.

Outro ponto relevante em relação às repúblicas é a demanda potencial desses serviços, que deve ser pensada não apenas em relação aos jovens que já completaram 18 anos, mas também em consideração àqueles de 16 a 17 anos que estão prestes a completar a maioridade. Estima-se com base nos censos anteriores que, em média, a cada dois anos, a demanda potencial pelos serviços de repúblicas alcance a ordem de 3,9 mil vagas. No entanto, tomando-se como exemplo os dados de 2018, quando apenas 152 jovens foram transferidos para as repúblicas e 538 continuaram vivendo nas instituiçóes de acolhimento, pode-se afirmar que se conhece o destino de menos de $20 \%$ dos jovens egressos dos serviços de acolhimento. Qual teria sido o destino dos demais jovens desligados por maioridade? Teriam conseguido uma família? Teriam alcançando a autonomia para se autossustentarem, arcando com sua própria sobrevivência? Ou estariam vivendo nas ruas e enfrentando outros tipos de vulnerabilidades e riscos?

É fundamental que tanto o Suas quanto o SGDCA tenham informaçôes sobre o destino desses jovens que foram separados de suas famílias de origem por açóes do Estado que visavam protegê-los e garantir-lhes o exercício do direito à convivência familiar. Como se fracassou no objetivo da retomada do convívio, pela reintegraçáo familiar ou pelo encaminhamento para adoçáo, é necessário que o Estado continue, por um tempo maior, provendo as garantias e as seguranças necessárias aos jovens que completam a maioridade dentro das instituiçóes. Assim, sugere-se que o conhecimento e o acompanhamento dessas trajetórias após o desligamento, assim como o acesso dos egressos de serviços de acolhimento a políticas mais consistentes de suporte e apoio, integrem a perspectiva de atualização do PNCFC. 
No que se refere à disponibilidade de informaçóes dos acolhidos, é mister notar que uma série de informaçóes relacionadas ao seu perfil, incluindo-se os motivos para o acolhimento, não estão disponíveis no Censo Suas, de sorte que seria relevante a integração de registros administrativos já disponíveis, como: i) o Prontuário Suas -Acolhimento; ii) o SNA, sob guarda do CNJ; e iii) o CadÚnico para programas sociais. Também cabe a realizaçáo de levantamentos específicos sobre segmentos dos acolhidos, como as realizadas por CNMP (2013) ou a idealizada pelo CMDCA de Curitiba-PR (Januário, Mottin e Provenzano, 2017). Nesse sentido, a busca da interoperabilidade das bases e, a partir disso, a criação de sistemas de indicadores nacionais podem contribuir para a consolidação da função da vigilância socioassistencial, no sentido do monitoramento e avaliação dos serviços de acolhimento para crianças e adolescentes, especialmente no que se refere: ao perfil dos acolhidos e suas famílias; as condiçóes que levam ao rompimento dos vínculos, a reintegração ao convívio familiar e a tomada de decisão pela colocação em adoção; os fatores de risco ao retorno aos serviços de acolhimento após tentativa de reintegração familiar ou adoção; além de estudos qualitativos sobre respectivas trajetórias.

Em suma, ainda que os avanços sejam muitos e significativos, permanecem desafios a serem observados no processo de atualização do PNCFC que se vislumbra. Deve-se buscar a consolidação das novas modalidades de acolhimento criadas no bojo do plano, tais como as famílias acolhedoras e as repúblicas, as quais seguem muito aquém do necessário. Ainda temos grande dificuldade em fazer com que a oferta de serviços de acolhimento, institucional e familiar, chegue em todos os municípios, independentemente do porte. Para tanto, é necessária a continuidade dos processos de regionalização e expansão qualificada iniciados em 2013. No tocante à qualidade do atendimento, é importante investir no aprimoramento dos planos individuais e no acompanhamento caso a caso, com ênfase nos meios para alcançar o objetivo de reintegração familiar ou, na sua impossibilidade, encaminhamento para adoção, ao mesmo tempo que se investe na participação dos acolhidos na vida comunitária e no fortalecimento da autonomia, bem como na preparação dos adolescentes para o desligamento do serviço. É fundamental também obter mais informações a respeito do perfil dos acolhidos, a fim de melhor direcionar os programas e os serviços socioassistenciais existentes, assim como os recursos das demais políticas em prol da promoção de seu desenvolvimento saudável e acesso a direitos. Afinal, o trabalho em rede contribui para abreviar o tempo de acolhimento, restituir o convívio familiar às crianças e aos adolescentes e assegurar a proteção a seu desenvolvimento e direitos enquanto a medida protetiva de acolhimento se faz necessária.

Este relatório mostra que, no que tange ao reordenamento dos serviços de acolhimento para crianças e adolescentes, o PNCFC trouxe frutos concretos na ampliaçáo do acesso ao direito à garantia da convivência familiar e comunitária das novas geraçóes. No entanto, não se pode perder de vista que a superaçáo dos desafios sinalizados nesta e em outras avaliaçóes depende tanto da continuidade do investimento e do aprimoramento de serviços e benefícios socioassistenciais, quanto da atuação e do aprimoramento das demais políticas que integram o SGDCA e do sistema de Justiça. 


\section{REFERÊNCIAS}

ASSIS, S.; FARIAS, L. O. (Orgs.). Levantamento nacional das crianças e adolescentes em serviço de acolhimento. São Paulo: Hucitec, 2013. 367 p.

BRASIL. Lei no ${ }^{8} .069$, de 13 de julho de 1990. Dispóe sobre o Estatuto da Criança e do Adolescente e dá outras providências. Brasília: Congresso Nacional, 13 jul. 1990.

Lei $n^{\circ}$ 8.742, de 7 de dezembro de 1993. Dispóe sobre a organização da assistência social e dá outras providências. Brasília: Congresso Nacional, 7 dez. 1993. Disponível em: $<$ https://bit.ly/3fSTdDs>. Acesso em: 23 jun. 2020.

Ministério da Assistência Social. Comitê para o Reordenamento dos Abrigos. Subsídios para a reflexáo na aplicaçáo da medida e funcionamento de programas em regime de abrigo. Brasília: CRA/Ministério da Assistência Social, 2003.

. Ministério do Desenvolvimento Social e Combate à Fome. Secretaria Nacional de Assistência Social. Política Nacional de Assistência Social. Brasília: SNAS, 2005a.

. Ministério do Desenvolvimento Social e Combate à Fome. Norma operacional básica - NOB/Suas. Brasília: MDS, 2005b.

Conselho Nacional dos Direitos da Criança e do Adolescente. Conselho Nacional de Assistência Social. Plano Nacional de Promoçáo, Proteçáo e Defesa do Direito de Crianças e Adolescentes à Convivência Familiar e Comunitária. Brasília: SEDH/PR, 2006.

Ministério do Desenvolvimento Social e Combate à Fome. Secretaria Nacional de Assistência Social. Orientaçóes Técnicas: serviços de acolhimento para crianças e adolescentes. Brasília: Secretaria Nacional de Assistência Social/MDS, jun. 2009.

. Lei no 13.257 , de 8 de março de 2016. Dispóe sobre as políticas públicas para a primeira infância e altera a Lei no ${ }^{\circ} .069$, de 13 de julho de 1990 (Estatuto da Criança e do Adolescente); o Decreto-Lei no 3.689, de 3 de outubro de 1941 (Código de Processo Penal); a Consolidação das Leis do Trabalho (CLT), aprovada pelo Decreto-Lei $\mathrm{n}^{\mathrm{o}} 5.452$, de $1^{\circ}$ de maio de 1943; a Lei no 11.770, de 9 de setembro de 2008; e a Lei no 12.662, de 5 de junho de 2012. Diário Oficial Uniáo, Brasília, 8 mar. 2016. Disponível em: <https://bit.ly/2zWcmFm>. Acesso em: 23 jun. 2020.

Lei no 13.509 , de 22 de novembro de 2017. Dispóe sobre adoçáo e altera a Lei $n^{\circ}$ 8.069, de 13 de julho de 1990; a Consolidaçáo das Leis do Trabalho; e a Lei no 10.406, de 10 de janeiro de 2002. Diário Oficial Uniáo, Brasília, 22 nov. 2017. Disponível em: <https://bit. ly/3eEjIfG>. Acesso em: 23 jun. 2020.

CALMON, P.; COSTA, A. T. M. Redes e governança das políticas públicas. RP3: Revista de Pesquisa em Políticas Públicas, n. 1, p. 1-29, jul. 2013.

CNMP - CONSELHO NACIONAL DO MINISTÉRIO PÚBLICO. Relatório da Infância e Juventude - Resoluçáo no 71/2011: um olhar mais atento aos serviços de acolhimento de crianças e adolescentes no país. Brasília: CNMP, 2013. Disponível em: <https://bit.ly/2Vc8SpB>. Acesso em: 23 jun. 2020.

CORES, G. H. Reordenamento Institucional: um estudo comparativo. 2014. Monografia (Especialização) - Escola Nacional de Administração Pública, Brasília, 2014.

FERRAZ, J. D. et al. O funcionamento do Programa de Proteção a Crianças e Adolescentes Ameaçados de Morte (PPCAAM) nas áreas de vulnerabilidade social no Rio de Janeiro. Revista de Políticas Públicas, v. 15, n. 2, p. 277-286, 2012. 
FONSECA, C.; CARDARELLO, A. Direitos dos mais e menos humanos. Horizontes antropológicos, v. 5, n. 10, p. 83-121, 1999.

GOFFMAN, E. Manicômios, prisóes e conventos. São Paulo: Ed. Perspectiva, 2003.

HOAGLIN, D. C.; IGLEWITZ, B.; TUKEY, J. W. Performance of some resistant rules for outlier labeling. Journal of the American Statistical Association, v. 81, n. 396, p. 991-999, 1986.

JANUÁRIO, E. M. U.; MOTTIN, F.; PROVENZANO, M. H. Diagnóstico da realidade social da infância e juventude do município de Curitiba. 1. ed. Curitiba: Núcleo Criativo Painel, 2017. v. 2. Disponível em: <https://bit.ly/3opkDWt>.

LEITE, C. C. Da doutrina da situação irregular à doutrina da proteção integral: aspectos históricos e mudanças paradigmáticas. Juizado da Infância e da Juventude, ano 3, v. 5, p. 9-24, mar. 2005.

NUNES, M. M. C. A. Acolhimento institucional e acolhimento familiar: uma análise sobre os desafios e entraves na implementação do Família Acolhedora em São Luís-MA. 2020. Dissertação (Mestrado) - Programa de Pós-Graduação em Políticas Públicas, Universidade Federal do Maranhão, São Luís, 2020.

ONU - ORGANIZAÇÃO DAS NAÇÓES UNIDAS. Diretrizes de cuidados alternativos à criança. [s.l.]: ONU, 2009. Disponível em: <https://bit.ly/3fd9Day>. Acesso em: 29 abr. 2020.

PEREIRA, J. M. F.; NERIS, M. S. M.; MELO, A. A. C. A. O direito à convivência familiar e comunitária na agenda pública no Brasil. In: SEMINÁRIO INTERNACIONAL DE ACOLHIMENTO FAMILIAR, 3., 2019, Campinas, São Paulo. Anais... Campinas: Paulus Editora, 20-23 nov. 2019.

SILVA, E. R. A. Os filhos do governo: a formação da identidade criminosa em crianças órfâs e abandonadas. São Paulo: Ática, 1997.

(Org.). O direito à convivência familiar e comunitária: os abrigos para crianças e adolescentes no Brasil. Brasília: Ipea; Conanda, 2004.

TJSP - TRIBUNAL DE JUSTIÇA DO ESTADO DE SÃO PAULO. Relatório do levantamento: adolescentes em situação de acolhimento institucional que irão completar a maioridade. São Paulo: TJSP, 2018. Disponível em: <https://bit.ly/2NqqDxj>. Acesso em: 23 jun. 2020 .

TORQUATO, M. et al. (Orgs.). Subsídios: orientações metodológicas para acolhimento de crianças e adolescentes em situação de rua. Brasília: O Pequeno Nazareno; Conanda, 2020.

UFMG - UNIVERSIDADE FEDERAL DE MINAS GERAIS. Relatório Final: projeto de pesquisa de desenvolvimento de metodologias, instrumentos e análises para determinar os custos (fixos, variáveis e outros) relativos à prestação de serviços socioassistenciais. Belo Horizonte: Núcleo Observatório de Custos e Economia da Saúde; Faculdade de Ciências Econômicas, 2018.

YÁNEZ, J. L. Os desafios do marco legal para a primeira infância. Brasília: Segraf, 2016. p. $86-88$. 

Ipea - Instituto de Pesquisa Econômica Aplicada

EDITORIAL

Chefe do Editorial

Reginaldo da Silva Domingos

Assistentes da Chefia

Rafael Augusto Ferreira Cardoso

Samuel Elias de Souza

Supervisão

Camilla de Miranda Mariath Gomes

Everson da Silva Moura

\section{Editoração}

Aeromilson Trajano de Mesquita

Anderson Silva Reis

Cristiano Ferreira de Araújo

Danielle de Oliveira Ayres

Danilo Leite de Macedo Tavares

Jeovah Herculano Szervinsk Junior

Leonardo Hideki Higa

\section{Capa}

Andrey Tomimatsu

Danielle de Oliveira Ayres

Flaviane Dias de Sant'ana

The manuscripts in languages other than Portuguese published herein have not been proofread.

\section{Livraria Ipea}

SBS - Quadra 1 - Bloco J - Ed. BNDES, Térreo

70076-900 - Brasília - DF

Tel.: (61) 2026-5336

Correio eletrônico: livraria@ipea.gov.br 

Composto em adobe garamond pro 11,5/13,8 (texto) Frutiger 67 bold condensed (títulos, gráficos e tabelas) Brasília-DF 



\section{Missão do Ipea}

Aprimorar as políticas públicas essenciais ao desenvolvimento brasileiro por meio da produção e disseminação de conhecimentos e da assessoria ao Estado nas suas decisões estratégicas. 